\title{
AN ANNOTATED AND UPDATED CHECKLIST OF THE HUNGARIAN DENDROFLORA
}

\author{
D. BARTHA \\ Institute of Botany and Nature Conservation, University of Sopron \\ H-9400 Sopron, Bajcsy-Zsilinszky u. 4, Hungary, E-mail: bartha.denes@uni-sopron.hu
}

(Received: 11 February 2021; Accepted: 29 July 2021)

The checklist includes tree, shrub, dwarf shrub, woody liana and epiphyte species that occur or have occurred in Hungary except the settlements and other intensively utilised objects. 437 dendrotaxa were included and evaluated in this list. This means 281 species, 22 subspecies, 128 nothospecies and 6 nothosubspecies. Based on the indigenat, 260 native, 92 alien and 9 cryptogenic dendrotaxa live in Hungary, furthermore 54 cultivated dendrotaxa and 22 dendrotaxa with questionable occurrence. Analysing the invasive status of alien species, 19 invasive or being in the early stages of invasion, 12 naturalised and 61 casual dendrotaxa can be distinguished. According to residence time status, the number of archaeophytes is 16 and that of neophytes is 76 . Of the 260 native dendrotaxa, 9 were extinct or presumably extinct. 44 dendrotaxa are considered to be proven endemic, and there are 8 subendemic. Of the 134 nothotaxa on the list, 14 are artificial and 120 are of natural origin.

Key words: alien plants, dendrotaxa, Hungary, hybrids, native plants, nomenclature, species list

\section{INTRODUCTION}

The purpose of species lists, flora lists, or according to current terminology standard lists and checklists, is to provide an account of the members of the flora of a given area, taking into account new knowledge of nomenclature, taxonomy, biogeography and ecology to utilise in basic and applied research, education, and practice (e.g. forestry, agriculture, nature conservation). This study undertakes to process the dendroflora of Hungary in such an approach.

In the last quarter of a century, checklists discussing the vascular flora have already been made in the surrounding countries of Hungary and in the neighbouring countries of Central and Southern Europe, such as: Albania (Barina et al. 2018), Austria (Gilli et al. 2019), Croatia (Nikolić 1994, 1997, 2000), Czech republic (Danihelka et al. 2012, Pyšek et al. 2012), Germany (Buttler and Hand 2008, Buttler et al. 2018, Wisskirchen and Haeupler 1998), Greece (Dimopoulos et al. 2013), Italy (Bartolucci et al. 2018, Galasso et al. 2018), Poland (Mirek et al. 2002), Romania (Oprea 2005), Serbia (Niketić and Tomović 2018), Slovakia (Marhold and Hindák 1998), Slovenia (Trpin and Vreš 1995), Switzerland (Juillerat et al. 2017), Ukraine (Mosyakin and Fedoronchuk 1999). 
The first checklist in Hungary in the current sense, processing vascular flora and covering the entire territory of the country, was compiled by Rezső Soó (Soó 1980), which is based on his detailed, multi-volume work on the processing of Hungarian flora (Soó 1964-1973). An abbreviated and improved version of this was later published by Szaniszló Priszter (Priszter 1985). A list of taxa supplemented with several attributes (e.g. floristic, coenological, ecological, nature conservation) was published a decade later by Horváth $e$ t al. (1995). After the turn of the millennium, Róbert Vidéki and Viktor Virók prepared a checklist (Vidéki and Virók 2004) to help the Hungarian flora mapping and the compilation of the plant identification book, but their publication was unfortunately not used in the compilation of the mentioned works. A list of taxa for archaeophytes (Terpó et al. 1999) and neophytes (Balogh et al. 2004) was also prepared based on a set of criteria.

The checklist containing only dendrotaxa was first published in Hungary a good quarter of a century ago (Bartha 1992-93), which was later followed by improved versions (Bartha 1999a, b). The list of adventive taxa of dendroflora has been published in several updated studies (Bartha 1999c, 2000, Bartha and Csiszár 2004). A special checklist containing only Rosa taxa was published by Kerényi-Nagy (2010). A recent list-like compilation was made of some degree endangered, and of invasive or potentially invasive alien tree and shrub species (Bartha 2019, 2020). The purpose of this list of dendrotaxa is to appear as an updated version of the previous lists compiled in a similar way, to draw attention to the changes, and to provide an incentive effect on the potential compilers of the long-missing list of vascular plant species in Hungary.

\section{MATERIAL AND METHODS}

Range of dendrotaxa and study area: The list includes tree, shrub, dwarf shrub, woody liana and epiphyte species that occur or have occurred in Hungary, but do not include semi-shrubs. The list does not take into account the woody plant species planted in Hungarian settlements (urban areas) or they only established there, due to their large number and the temporality of establishment (these can be studied in Bartha's (2020) work), and also the intensively utilised objects of the urban suburbs (e.g. Christmas tree plantations, seed orchards, castle parks, arboretums, motorways).

Systematic and taxonomy: The checklist lists dendrotaxa in alphabetical order, and the valid family names are given in each genus based on modern molecular genetic knowledge, established by the Angiosperm Phylogeny Group (APG IV. 2016, Stevens 2001 onwards, WCSP 2021) for angiosperms and Christenhusz et al. (2011) for gymnosperms. Within genera, the list includes species aggregates in the original interpretation of Manton (1958), species, specioids in the interpretation of Jirásek (1964), and subspecies. The delimitation of the 
latter - which has caused many misunderstandings so far - was based on Govaerts' conception (WCSP 2021): “Distribution range separate (so that nonoverlapping rings can be drawn round them on a map) or nearly so, gene flow absent or very restricted between the infraspecific populations and differing in characters that are significant for taxonomic species differentiation within the genus." The previously used s. 1. (sensu lato) and s. str. (sensu stricto) taxon conceptions were discarded due to their difficult interpretation, and the hierarchical species aggregate and species or species and subspecies categories were used instead. In addition, the list includes hybrid nothospecies aggregate, hybrid species (nothospecies), and hybrid subspecies (nothosubspecies). Interpretation of nothotaxa is based on the work of Stace et al. (2016).

Nomenclature: The scientific names were given on the basis of international databases (Euro + Med 2006 onwards, ILDIS 2010 onwards, IPNI 2004 onwards, TPL 2013 onwards, POWO 2021), and in case of any discrepancies, individual consideration and decision was made. Application of nomenclature rules were applied to natural taxa according to ICN (= International Code of Nomenclature for Algae, Fungi, and Plants) (Turland et al. 2018, Shenzhen Code; Wiersema et al. 2018+ continuously updated, Appendices I-VII), for cultivated taxa according to the ICNCP (= International Code of Nomenclature for Cultivated Plants) (Brickel et al. 2016). Abbreviations of author names follow Brummit and Powell (1992) as incorporated in and further developed by the IPNI (IPNI 2004 onwards).

Valid taxon names are printed in bold italics, except for family names, species aggregate, nothospecies aggregate, and auctor names. Family names and auctor names are published in normal letters, species and nothospecies aggregate names in italics, not bold letters. If there is a new name combination for the taxon, or the name is validated at a different rank than in the original protologue, the basionym is always given. In the case of synonym names only the more frequently used in Hungary were indicated, a complete list of them is impossible and meaningless due to space limitations. In the case of hybrids, the hybrid parents are also listed in alphabetical order. Basionym, synonym, and hybrid parent names are in italics, not in bold.

The nomenclature notations and abbreviations used and their resolution are as follows: agg. = aggregatus (aggregate, a group of closely related species within a genus); auct. = auctorum (of author(s), of various authors but not the original one); bas. = basionymon (basionym); comb. nov. = combinatio nova (new combination); cv. = cultivarietas (cultivar, a cultivated variety); em. = emendatus (amended), emendavit (an by); et = et (and, \&); et al. = et alii (and others); ex = from; excl. = exclusus (excluded); f. = forma (form); gen. fem. cons. = genus femininum conservandum (feminine gender to be conserved); gen. masc. cons. = genus masculinum conservandum (masculine gender to be conserved); hort. = hortorum (invalid horticultural name); in = in (to connect 
the names of two persons); incl. = inclusus (included); microsp., microspp. $=$ microspecies (a unit of a species aggregate); nom. cons. = nomen conservandum (conserved name); nom. cons. prop. $=$ nomen conservandum propositum (a name proposed for conservation); nom. illeg. = nomen illegitimum (illegitimate name); nom. inval. = nomen invalidum (name invalid for some other reason); nom. nov. = nomen novum (replacement name); nom. nud. = nomen nudum (name invalid since without description); nom. rej. $=$ nomen rejiciendum (rejected name); nom. rej. prop. $=$ nomen rejiciendum propositum (a name proposed for rejection); nom. utique rej. = nomen utique rejiciendum (supressed name); non = not; nothosubsp. = nothosubspecies (nothosubspecies); ortho. = versio orthographiam (orthographic variant, spelling variant); orth. cons. $=$ orthographia conservanda (orthography conserved); . p. $=$ pro parte (partly, in part); s. l. = sensu lato (in a broad sense); s. n. = sine nomine (without name); sp. = species (species); s. str. = sensu stricto (in a narrow sense); sensu [author] = according to [author]; subsp. = subspecies (subspecies); stat. nov. = status novus (name at new rank); syn. = synonymon (synonym); var. = varietas (variety); vel $=$ or.

Life forms: Life forms are given based on detailed categories developed by Bartha (1999d) based on the Raunkiaer system, but only the main groups are reported here, which are: $\mathrm{T}=$ tree, $\mathrm{S}=$ shrub, $\mathrm{DS}=\mathrm{d}$ warf shrub, $\mathrm{L}=$ liana, $\mathrm{E}=$ epiphyte. Transitional types (T-S, S-L) are possible.

Status: Status is given based on several criteria, for example groups according to indigenat, invasion status, residence time status, cultivation, endemity, origin of hybrid taxa are indicated.

a. Indigenat (origin) and invasion status: The categories and definitions follow the work of Lambdon et al. (2008), which are slightly modified as follows: $\mathrm{N}=$ native plants (indigenous) are taxa that have originated in a given area without human involvement or that have arrived there without intentional or unintentional intervention of humans from an area in which they are native. The definition excludes products of hybridisation involving alien taxa since human involvement in this case includes the introduction of an alien parent. $\mathrm{A}=$ alien plants (exotic, introduced, non-native, non-indigenous) are taxa in a given area whose presence there is due to intentional or unintentional human involvement, or which have arrived there without the help of people from an area in which they are alien. Taxa can be alien to any definable area, e.g. continents, islands, bio- or ecoregions, or any political entity (e.g., countries, states, provinces). Within this category, the following can be distinguished: Cas = casual alien plants are taxa that may reproduce occasionally outside cultivation in an area, but that eventually die out because they do not form self-replacing populations, and rely on repeated introductions for their persistence. Nat $=$ naturalised alien plants are taxa that sustain self-replacing populations for a period of time long enough to experience extreme climatic events in the 
area, and reproduce without direct intervention by people (or in spite of human intervention) by recruitment from seed or vegetative parts capable of independent growth. Inv = invasive alien plants are a subset of naturalised plants that produce reproductive offspring, often in very large numbers, at considerable distances from the parent plants and thus have the potential to spread over a large area. The definition is not bound to a type of habitat, hence a species may be invasive in natural or human-made habitats.

In addition to the above two main categories ( $\mathrm{N}$ and A), Carlton's (1996) interpretation also distinguishes the following category: $\mathrm{C}=$ cryptogenic plants are those in which it cannot be with certainty decided whether they are native or alien to a region.

The indigenate is determined by Bartha et al. (2015), taking into account the special literature on the taxon, the invasion status was granted according to Bartha (2020).

b. Residence time status: The categories and definitions follow the work of Lambdon et al. (2008), which are slightly modified as follows: Arch = archaeophytes are alien species introduced to the region during the period since the beginning of Neolithic agriculture and the end of Medieval (discovery of Americas, approximately the year 1500 AD). Neo = neophytes are alien species introduced to the region after the year $1500 \mathrm{AD}$. Residence time status was determined on the basis of Gyulai (2001) and the literature on taxa.

c. Other categories: Cult = cultivated plants are taxa or nothotaxa that, regardless of their indigenat and origin, are propagated and maintained by humans for some purpose. Hung.? = taxa and nothotaxa have been given this category whose occurrence in Hungary is uncertain and needs to be confirmed.

It should be emphasised that the above categories may be combined for individual taxa and nothotaxa. Some important combinations are interpreted as follows: $\mathrm{N} / \mathrm{Nat}$ or Cas = native in one part of Hungary and naturalised or casual in another (e.g. Fraxinus ornus, Alnus incana); N / Cult = native in Hungary and also cultivated at the same time (e.g. Prunus avium); N / Cult / Cas = native and cultivated in Hungary, but escaped from cultivation and casual in appearance outside the native area (e.g. Taxus baccata); Cult / Inv or Nat or Cas = cultivated in Hungary, escaped from cultivation and became invasive, naturalised or casual (e.g. Acer negundo, Juglans regia, Platycladus orientalis); Cult / Arch or Neo = only cultivated archaeophyte or neophyte in Hungary, no escape can be experienced (e.g. Prunus persica, Taxodium distichum).

d. Endemity: In its own interpretation, End = endemic ("Hungarian endemic $^{\prime \prime}$ ) is a taxon that occurs or has occurred only within the area of Hungary, and SubE = subendemic is a taxon that occurs or has occurred in Hungary and in a neighbouring country (Austria, Slovakia, Ukraine, Romania, Serbia, Croatia or Slovenia), regardless of its area size. The definition of endemity is based on the work of Bartha (2019). 
e. Origin of hybrid taxa: $\mathrm{Ntl}=$ natural (spontaneous) hybrid is a taxon whose development human has no direct, at most only indirect role, Art = artificial (anthropogenic) hybrid is a taxon whose development human has direct role. The origin of hybrid taxa was determined based on the literature reported for nothotaxa.

Symbols: ? = questionable (e.g. taxonomically doubtful, records from Hungary need confirmation, doubtful status), $t=$ extinct or possibly extinct, $x=$ hybrid formula.

Literature: The literature on the genera discusses the current interpretation and division of the genus, the literature on the lower taxa of the genera deals with taxonomic and nomenclatural problems, its occurrence in Hungary, and the status of the taxon. For the most part, only the relevant literature of the last quarter of a century has been considered.

\section{RESULTS}

The current list of dendroflora in Hungary, the indicators assigned to the taxa and the literature are given in Appendix 1. A total of 437 dendrotaxa (species and subspecies, nothospecies and nothosubspecies) were included and evaluated in this list. This means 281 species with no or only one subspecies living in Hungary (including the autonyme subspecies), 4 species (Acer tataricum, Daphne cneorum, Prunus mahaleb, Ulmus minor) with 2-2 subspecies living in Hungary and 4 more species (Cornus sanguinea, Crataegus monogyna, Quercus robur, Viscum album) whose 3-3 subspecies live in Hungary. Number of subspecies analysed is 22 . For hybrid taxa (nothotaxa), there are 128 nothospecies where there are no nothosubspecies or only one nothosubspecies, for another 1-1 nothospecies (Crataegus $\times$ subsphaerica, C. ×media) 2 and 3 nothosubspecies were listed. Number of nothosubspecies analysed is 6 . There is one another species (Vitis vinifera) within which 2 subspecies and 1 nothosubspecies have been added to the list. In addition, 6 species aggregate ( $\mathrm{Cra}-$ taegus rhipidophylla agg., Prunus domestica agg., Pyrus communis agg., Quercus petraea agg., Q. pubescens agg., Vaccinium oxycoccos agg.) and 2 nothospecies aggregate (Crataegus $\times$ macrocarpa agg., $C$. $\times$ subsphaerica agg.) have also been set up for better placement and interpretation of certain critical taxa. The microspecies included here were evaluated by species rank.

Based on the indigenat, 260 native, 92 alien and 9 cryptogenic dendrotaxa live in Hungary, furthermore 54 cultivated dendrotaxa and 22 dendrotaxa with questionable occurrence. Their distribution based on taxonomic ranks (species, subspecies, nothospecies, nothosubspecies) is shown in Table 1. Analysing the invasive status of alien species, 19 invasive or being in the early stages of invasion, 12 naturalised and 61 casual dendrotaxa can be distinguished. 


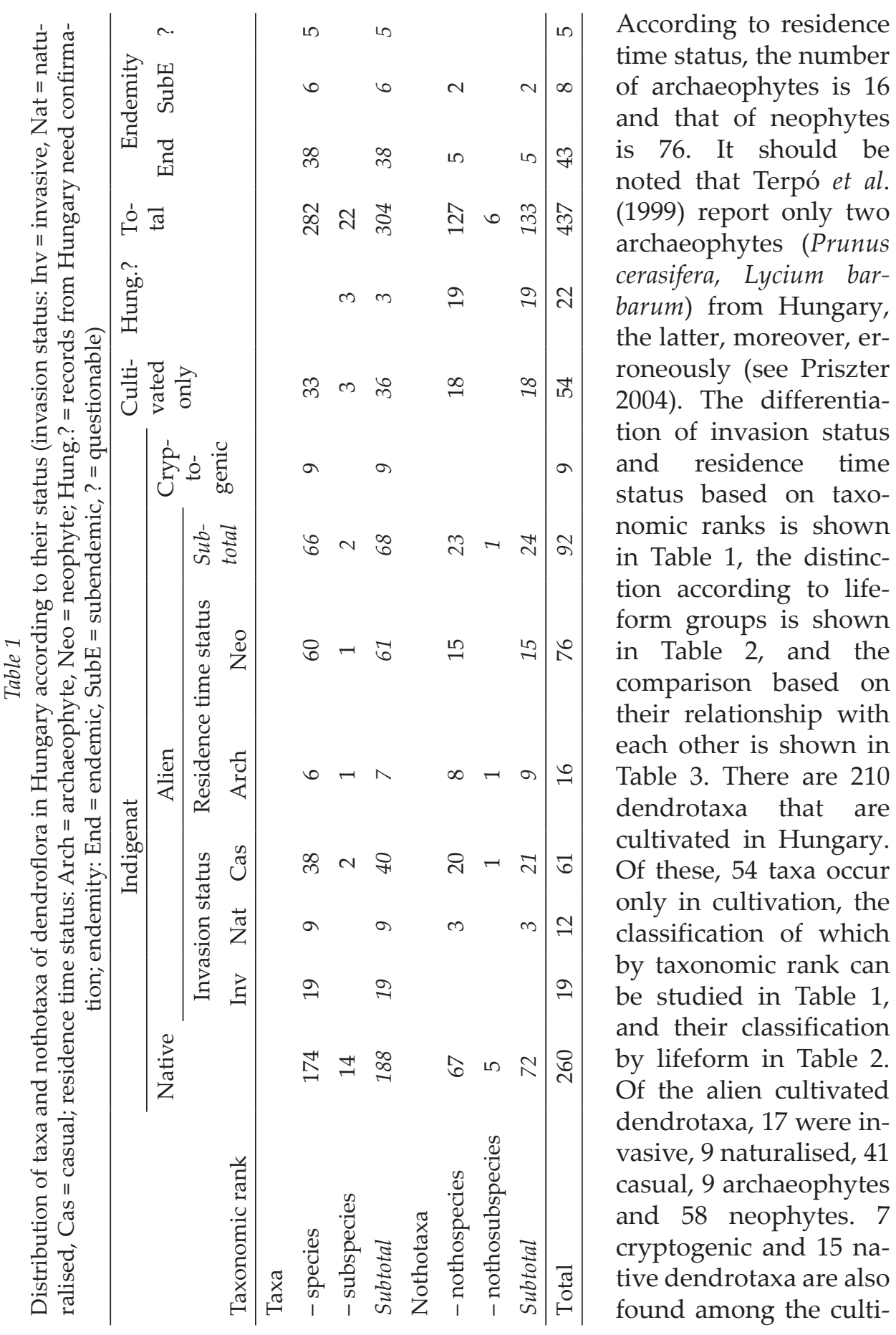


Table 2

Distribution of dendroflora members in Hungary according to their lifeform and status (life form: $\mathrm{T}=$ tree, $\mathrm{S}=$ shrub, $\mathrm{DS}=$ dwarf shrub, $\mathrm{L}=$ liana, $\mathrm{E}=$ epiphyte, $\mathrm{T}-\mathrm{S}$ and $\mathrm{S}-\mathrm{L}=$ transitional types; Invasion status: $\mathrm{Inv}=$ invasive, Nat = naturalised, Cas = casual; Hung.? = records from Hungary need confirmation)

\begin{tabular}{|c|c|c|c|c|c|c|c|c|}
\hline \multirow{3}{*}{$\begin{array}{l}\text { Life } \\
\text { form }\end{array}$} & \multicolumn{5}{|c|}{ Indigenat } & \multirow{3}{*}{$\begin{array}{c}\text { Cultivated } \\
\text { only }\end{array}$} & \multirow{3}{*}{ Hung.? } & \multirow{3}{*}{ Tota } \\
\hline & \multirow[t]{2}{*}{ Native } & \multicolumn{3}{|c|}{ Alien } & \multirow{2}{*}{$\begin{array}{c}\text { Crypto- } \\
\text { genic }\end{array}$} & & & \\
\hline & & Inv & Nat & Cas & & & & \\
\hline $\mathrm{T}$ & 113 & 10 & 6 & 36 & 7 & 44 & 4 & 220 \\
\hline $\mathrm{T}-\mathrm{S}$ & 10 & 2 & & 3 & & & 4 & 19 \\
\hline$S$ & 118 & 4 & 4 & 11 & 2 & 6 & 11 & 156 \\
\hline S-L & 2 & & & & & & & 2 \\
\hline DS & 10 & & 2 & & & & 1 & 13 \\
\hline E & 4 & & & & & & & 4 \\
\hline $\mathrm{L}$ & 4 & 3 & & 11 & & 4 & 2 & 24 \\
\hline Total & 261 & 19 & 12 & 61 & 9 & 54 & 22 & 438 \\
\hline
\end{tabular}

Table 3

Distribution of alien members of the Hungarian dendroflora by invasion status and residence time status

\begin{tabular}{lcccc}
\hline \multirow{2}{*}{ Residence time status } & \multicolumn{3}{c}{ Invasion status } & \multirow{2}{*}{ Total } \\
\cline { 2 - 4 } & Invasive & Naturalised & Casual & \\
\hline Archaeophyte & - & 3 & 11 & 14 \\
Archaeophyte? & - & - & 2 & 2 \\
Neophyte & 19 & 9 & 48 & 76 \\
\hline Total & 19 & 12 & 61 & 92 \\
\hline
\end{tabular}

Table 4

Distribution of endemic and subendemic members of the Hungarian dendroflora

\begin{tabular}{lccc}
\hline Endemity & Native & Nativet & Cryptogenic \\
\hline Endemic & 43 & 1 & - \\
Endemic? & - & - & 2 \\
Endemic? or subendemic? & 2 & - & - \\
Subendemic & 8 & - & - \\
Subendemic? & 1 & - & - \\
Not endemic or subendemic & 197 & 8 & 7 \\
\hline Total & 251 & 9 & 9 \\
\hline
\end{tabular}


vated taxa. 22 nothotaxa are cultivated in Hungary, the distribution of the parents indigenat, and invasive and residence time status in the case of alien parents are shown in Table 5.

Of the 260 native dendrotaxa, 9 were extinct (Andromeda polifolia subsp. polifolia, Ostrya carpinifolia, Ribes petraeum, Rosa glauca, R. stylosa, Salix myrsi-

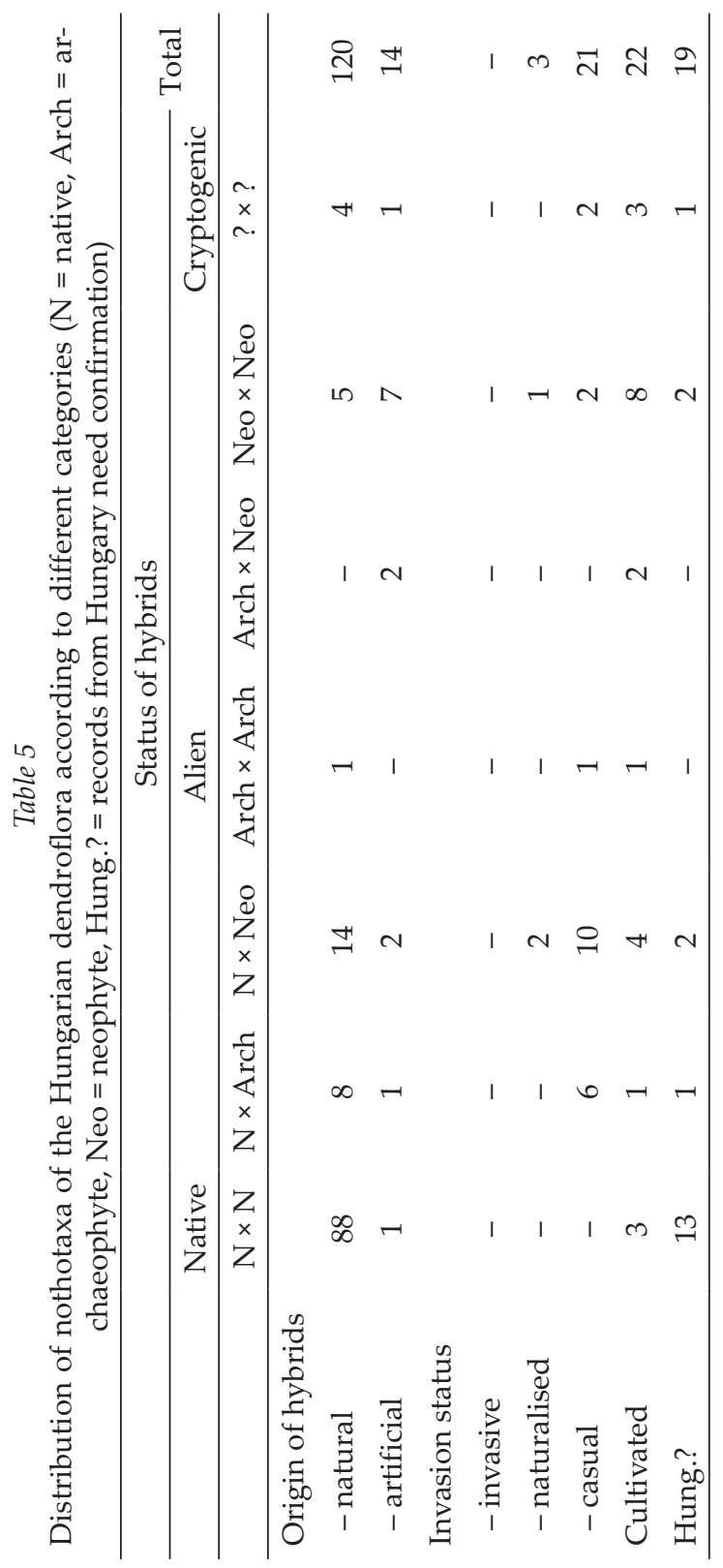
nifolia subsp. myrsinifolia - the latter's planted stand elsewhere has become established) or presumably extinct (s. n. [Alnus incana subsp. incana $\times A$. alnobetula subsp. alnobetula], $A$. xpseudoglutinosa, Rosa $\times$ budensis). 44 dendrotaxa are considered to be proven endemic (of which Sorbus s. 1. includes 5 species of Aria, 34 species of Karpatiosorbus, and from the genus Rosa the Rosa $\times$ barthae, $R$. ×borhidiana, $R$. ×budensis, R. ×pomazensis, $R$. xvictoria-hungarorum), in the case of 2 cryptogenic dendrotaxa (Acer acuminatilobum, Pyrus magyarica) the endemity is questionable, 2 dendrotaxa (Aria zolyomii, Hedlundia buekkensis) has not yet been proved to be endemic or subendemic, and there are 8 subendemic (Aria javorkana, A. subdanubialis, Crataegus $\times$ degenii, $C$. nigra, Rosa xbraunii, $R$. facsarii, R. kmetiana, $R$. zalana) and 1 questionable subendemic (Hed- 
lundia hazslinszkyana) taxa. It should be noted that the Aria thaiszii (Soó) Sennikov et Kurtto described from Hungary - in contrast to the previous data Mikoláš et al. (2017) - is not found in Hungary, only in Slovakia. The distribution of native and cryptogenic dendrotaxa by endemic categories is shown in Table 4, and the distribution by taxonomic categories is shown in Table 1.

Of the 134 nothotaxa on the list, 14 are artificial and 120 are of natural origin. Nothotaxa where all parents are native are considered native, their number is 89 . Non-native are nothotaxa where at least one of the parents is an alien, their number is 40 . In 5 cases, the status of the parents could not be clearly determined, and the occurrence of 19 nothotaxa in Hungary has yet to be proven. The indigenat of the parents, and invasive and residence time status in the case of alien parents are shown in Table 5.

Acknowledgements - This project was supported by Institute of Botany and Nature Conservation, University of Sopron, Hungary.

\section{REFERENCES}

Adams, R. P., Arnold, M. A., King, A. R., Denny, G. C. and Creech, D. (2012): Taxodium (Cupressaceae): one, two or three species? Evidence from DNA sequences and terpenoids. - Phytologia 94: 159-168.

Ahrendt, L. W. A. (1961): Berberis and Mahonia. - J. Linn. Soc. London (Botany) 57(369): $1-410$.

Andrés-Hernández, A. R., Terrazas, T., Salazar, G. and Ochoterena, H. (2014): Phylogenetic analysis based on structural and combined analysis of Rhus s.s. (Anacardiaceae). Bot. J. Linn. Soc. 176(4): 452-468. https://doi.org/10.1111/boj.12222

APG IV. (2016): An update of the angiosperm phylogeny group classification for the orders and families of flowering plants: APG IV. - Bot. J. Linn. Soc. 181: 1-20. https://doi.org/10.1111/j.1095-8339.2009.00996.x.

Ardenghi, N. M. G., Banfi, E. and Galasso, G. (2015): A taxonomic survey of the genus Vitis L. (Vitaceae) in Italy, part II: the 'Euro-American' hybrids. - Phytotaxa 224(3): 163-198. https://doi.org/10.11646/phytotaxa.224.3.2

Ardenghi, N. M. G., Galasso, G., Banfi, E., Zoccola, A., Foggi, B. and Lastrucci, L. (2014): A taxonomic survey of the genus Vitis L. (Vitaceae) in Italy, with special reference to Elba Island (Tuscan Archipelago). - Phytotaxa 166(3): 232-246. https://doi.org/10.11646/phytotaxa.166.3.1

Ashburner, K. and McAllister, H. A. (2013): The genus Betula: a taxonomic revision of birches. - Royal Botanic Gardens, Kew, 431 pp.

Auvray, G. and Malécot, V. (2013): A revision of Cytisus sections Alburnoides, Spartopsis and Verzinum (Genisteae, Fabaceae). - Edinb. J. Bot. 70(1): 71-120. https://doi.org/10.1017/S0960428612000352

Babos, K. and Bertin, P. (1998): Is common walnut (Juglans regia) native to Hungary? Acta Bot. Hung. 41(1-4): 11-16. 
Bailey, V. L. (1962): Revision of the genus Ptelea (Rutaceae). - Brittonia 14(1): 1-45. https://doi.org/10.2307/2805316

Balogh, L. (2012): Illatos nyáriorgona (Buddleja davidii Franchet). - In: Csiszár, Á. (ed.): Inváziós növényfajok Magyarországon. [Invasive alien plant species in Hungary.] Nyugat-magyarországi Egyetem Kiadó, Sopron, pp. 189-193.

Balogh, L., Dancza, I. and Király, G. (2004): A magyarországi neofitonok időszerü jegyzéke, és besorolásuk inváziós szempontból. [Timely list of neophytes in Hungary and their classification from the point of view of invasion.] - In: Mihály, B. and Botta-Dukát, Z. (eds): Biológiai inváziók Magyarországon. Özönnövények. [Biological invasions in Hungary. Invasive plant species.] A KvVM tanulmánykötetei 9, TermészetBúvár Alapítvány Kiadó, Budapest, pp. 61-92.

Barabits, E. (2007): A Sorbus bakonyensis (Jáv.) Kárp. taxonómiai revíziója - új berkenye fajok a magyar flórában. [New apomictic taxa of Sorbus from the Bakony Mountains.] - Tilia 13: 5-48.

Baráth, Z. (1956): Hazai Euonymusainkról. [The Euonymus taxa in Hungary.] - Bot. Közlem. 46: 235-249.

Barina, Z. and Király, G. (2014): Taxonomic re-evaluation of the enigmatic Pyrus magyarica (Rosaceae). - Phytotaxa 167(1): 133-136. https://doi.org/10.11646/phytotaxa.167.1.10

Barina, Z., Somogyi, G., Pifkó, D. and Rakaj, M. (2018): Checklist of vascular plants of Albania. - Phytotaxa 378: 1-339. https://doi.org/10.11646/phytotaxa.378.1.1

Bartha, D. (1992-93): A magyarországi dendroflóra tagjainak florisztikai, cönológiai, ökológiai és természetvédelmi mutatói. [Floristical, cenological, ecological and nature conservation indexes of the Hungarian dendroflora.] - Erd. Faip. Tud. Közlem. 38-39: 13-32.

Bartha, D. (1996): Der Speierling (Sorbus domestica L.) in Ungarn. - Corminaria 6: 5-6.

Bartha, D. (1999a): Annotated checklist of the Hungarian dendrotaxa. - Tilia 7(Suppl.): 31-44.

Bartha, D. (1999b): Floristical, cenological, ecological and nature conservation indexes of the Hungarian dendrotaxa. - Tilia 7(Suppl.): 45-64.

Bartha, D. (1999c): Adventive dendrotaxa of Hungary. - Tilia 7(Suppl.): 81-90.

Bartha, D. (1999d): Bewertung der Dendroflora Europas auf Grund der Lebensformen. Tilia 7(Suppl.): 3-30.

Bartha, D. (1999e): Tőzegrozmaring (Andromeda polifolia L.). - Tilia 7: 87-88.

Bartha, D. (1999f): Komlógyertyán (Ostrya carpinifolia Scop.). - Tilia 7: 43-47.

Bartha, D. (1999g): Feketedő füz (Salix nigricans Sm.). - Tilia 7: 60-62.

Bartha, D. (1999h): Csipkés gyöngyvessző (Spiraea crenata L.). - Tilia 7: 163-165.

Bartha, D. (2000): A magyarországi dendroflóra adventív taxonjai. [Adventive taxa of the Hungarian dendroflora.] - Tilia 9: 232-240.

Bartha, D. (2004): A Magyarországon előforduló nyár (Populus L.) taxonok határozókulcsa és rövid jellemzése. [Short description and key to the poplar taxa (Populus L.) existing in Hungary.] - Flora Pann. 2(2): 85-101.

Bartha, D. (2005): Ist die Graupappel eine eigene Art? Taxonomische Untersuchungen an den Populationen der Weisspappel (Populus alba L.). - Allg. Forst Zeitschr. / Der Wald 60(5): 252-254.

Bartha, D. (2007): A Cerasus Miller nemzetség nothotaxonjai Magyarországon. [Nothotaxa of Cerasus Miller in Hungary.] - Tilia 13: 49-75.

Bartha, D. (2011): Bastarde zwischen Kirschenarten (Cerasus Mill.; Rosaceae) in Mitteleuropa. - Mitt. Deutsch. Dendrol. Gesell. 96: 57-65. 
Bartha, D. (2015): Eine wenig bekannte Esche: die Ungarische Esche Fraxinus angustifolia Vahl. subsp. danubialis Pouzar. Teil I. - Mitt. Deutsch. Dendrol. Gesell. 100: 197-204.

Bartha, D. (2016): Eine wenig bekannte Esche: die Ungarische Esche Fraxinus angustifolia Vahl. subsp. danubialis Pouzar. Teil II. - Mitt. Deutsch. Dendrol. Gesell. 101: 55-68.

Bartha, D. (2019): Vörös Lista. Magyarország veszélyeztetett fa- és cserjefajai. / Red List. Threatened tree and shrub species of Hungary. - Soproni Egyetem Kiadó / University of Sopron Press, Sopron, $59 \mathrm{pp}$.

Bartha, D. (2020): Fekete Lista. Magyarország inváziós fa- és cserjefajai. / Black List. Invasive tree and shrub species of Hungary. * Szürke Lista. Magyarország potenciálisan inváziós fa- és cserjefajai. / Grey List. Potentially invasive tree and shrub species of Hungary. - Soproni Egyetem Kiadó / University of Sopron Press, Sopron, 84 pp.

Bartha, D. and Bőhm, É. I. (2010): Vastaggallyú körte és rokonai (Pyrus nivalis Jacq. agg.). - Tilia 15: 158-190.

Bartha, D. and Csiszár, Á. (2004): Adventive Taxa in der ungarischen Dendroflora. - Mitt. Deutsch. Dendrol. Gesell. 89: 149-162.

Bartha, D. and Csiszár, Á. (2008a): Common hackberry (Celtis occidentalis L.). - In: BottaDukát, Z. and Balogh, L. (eds): The most important invasive plants in Hungary. Institute of Ecology and Botany. Hungarian Academy of Sciences, Vácrátót, pp. 95-102.

Bartha, D. and Csiszár, Á. (2008b): Russian olive (Elaeagnus angustifolia L.). - In: Botta-Dukát, Z. and Balogh, L. (eds): The most important invasive plants in Hungary. Institute of Ecology and Botany. Hungarian Academy of Sciences, Vácrátót, pp. 85-93.

Bartha, D. and Kerényi-Nagy, V. (2010a): Fekete galagonya (Crataegus nigra Waldst. et Kit.). - Tilia 15: 54-74.

Bartha, D. and Kerényi-Nagy, V. (2010b): A magyar vagy fekete galagonya (Crataegus nigra Waldst. et Kit.) infraspecifikus taxonómiája és aktuális elterjedése. [Infraspecific taxonomy and current distribution of the Hungarian or Black Hawthorn (Crataegus nigra Waldst. et Kit.).] - Magyar Biológiai Társaság XXVIII. Vándorgyülés előadásainak összefoglalói, Budapest, pp. 117-122.

Bartha, D. and Király, G. (1999): Bérci ribiszke (Ribes petraeum Wulf.). - Tilia 7: 152-153.

Bartha, D. and Markovics, T. (2010): Havasi éger (Alnus viridis (Chaix) DC.). - Tilia 15: 7-20.

Bartha, D. and Raisz, Á. (2004): Untersuchungen zur Variabilität von Blattmerkmalen innerhalb der Krone bei Fagus sylvatica und Fagus orientalis. - Beitr. Forstwirtsch. und Landschaftsökol. 38(4): 169-178.

Bartha, D., Csiszár, Á. and Zsigmond, V. (2008): Black locust (Robinia pseudoacacia L.). - In: Botta-Dukát, Z. and Balogh, L. (eds): The most important invasive plants in Hungary. Institute of Ecology and Botany. Hungarian Academy of Sciences, Vácrátót, pp. 63-76.

Bartha, D., Kerényi-Nagy, V. and Molnár, Cs. (2011): Acer acuminatilobum J. Papp (1958) - Matra-ancient-maple. - Maple Soc. Newsl. 21(2): 5-9.

Bartha, D., Kevey, B. and Tiborcz, V. (2012): Current and 20th century distributions of Vitis sylvestris in Hungary. - Folia Oecol. 39(2): 99-106.

Bartha, D., Király, G., Schmidt, D., Tiborcz, V., Barina, Z., Csiky, J., Jakab, G., Lesku, B., Schmotzer, A., Vidéki, R., Vojtkó, A. and Zólyomi, Sz. (2015): Magyarország edényes növényfajainak elterjedési atlasza / Distribution atlas of vascular plants of Hungary. - Nyugatmagyarországi Egyetem Kiadó / University of West Hungary Press, Sopron, 329 pp.

Bartha, D., Vidéki, R. and Máté, A. (2004): A csipkés gyöngyvessző (Spiraea crenata L.) magyarországi előfordulása. [The occurrence of crenated spirea (Spiraea crenata L.) in Hungary.] - Flora Pann. 2(2): 119-127. 
Bartolucci, F. and Galasso, G. (2019): Nomenclatural novelties. Ulmus minor L. subsp. canescens Bartolucci \& Galasso, subsp. nov. - Italian Botanist 7: 138-139. https://doi.org/10.3897/italianbotanist.7.36148

Bartolucci, F., Peruzzi, L., Galasso, G., Albano, A., Alessandrini, A., Ardenghi, N. M. G., Astuti, G., Bacchetta, G., Ballelli, S., Banfi, E., Barberis, G., Bernardo, L., Bouvet, D., Bovio, M., Cecchi, L., Di Pietro, R., Domina, G., Fascetti, S., Fenu, G., Festi, F., Foggi, B., Gallo, L., Gottschlich, G., Gubellini, L., Iamonico, D., Iberite, M., Jiménez-Mejías, P., Lattanzi, E., Marchetti, D., Martinetto, E., Masin, R. R., Medagli, P., Passalacqua, N. G., Peccenini, S., Pennesi, R., Pierini, B., Poldini, L., Prosser, F., Raimondo, F. M., Roma-Marzio, F., Rosati, L., Santangelo, A., Scoppola, A., Scortegagna, S., Selvaggi, A., Selvi, F., Soldano, A., Stinca, A., Wagensommer, R. P., Wilhalm, T. and Conti, F. (2018): An updated checklist of the vascular flora native to Italy. - Plant Biosyst. 152(2): 179-303. https://doi.org/10.1080/11263504.2017.1419996

Batiz, E. (2000): A körte (Pyrus) nemzetség morfológiai és növényföldrajzi feldolgozása. [Morphological and phytogeographical processing of the genus Pyrus.] - Tilia 9: 163-216.

Bauer, N. (2015): Sorbus udvardyana Somlyay \& Sennikov a Balaton-felvidék keleti dolomitterületén. [Sorbus udvardyana Somlyay \& Sennikov in the eastern part of the Balaton Uplands.] - Kitaibelia 20(1): 55-58. https://doi.org/10.17542/kit.20.55

Becker, H. (2000): European mistletoe - taxonomy, host trees, parts used, physiology. - In: Bussing, A. (ed.): Mistletoe: The Genus Viscum. Harwood Academic Publishers, pp. 31-41.

Belyaeva, I. V. (2009): Nomenclature of Salix fragilis L. and a new species, S. euxina (Salicaceae). - Taxon 58: 1344-1348. https://doi.org/10.1002/tax.584021

Belyaeva, I. V., Epantchintseva, O. V., Govaerts, R. H. A., McGinn, K., Hunnex, J. and Kuzovkina, Y. A. (2018): The application of scientific names to plants in cultivation: Salix vitellina L. and related taxa (Salicaceae). - Skvortsovia 4: 42-70.

Bényei-Himmer, M., Tóth, E. Gy., Lengyel, Sz., Pintér, I., Bisztray, Gy. D. and Höhn, M. (2017): Hedera crebrescens (Araliaceae) a newly identified diploid taxon and triploid ivies from Hungary.-Studia bot. hung. 48(2): 225-252. https://doi.org/10.17110/StudBot.2017.48.2.225

Bodonczi, L. and Havas, M. (1999): Füles füz (Salix aurita L.). - Tilia 7: 63-68.

Boom, B. K. (1957): Populus canadensis Moench versus P. euramericana Guinier. - Acta Bot. Neerl. 6(1): 54-59. https://doi.org/10.1111/j.1438-8677.1957.tb00572.x

Borovics, A., Kézdy, P. and Szmorad, F. (1999): Magyar tölgy (Quercus frainetto Ten.). Tilia 7: 48-54.

Bőhm, É. I. (2007): Fokozottan védett növényfajunk, a magyar vadkörte (Pyrus magyarica Terpó), valamint alakkörének kutatása Magyarországon. [Research of our highly protected plant species, Pyrus magyarica Terpó and its forms in Hungary.] - Tilia 13: 95-104.

Bőhm, É. I. (2010): Magyar vadkörte (Pyrus magyarica Terpó). - Tilia 15: 149-157.

Bölöni, J. (1999a): Madárbirs fajok (Cotoneaster spp.). - Tilia 7: 193-232.

Bölöni, J. (1999b): Bokros koronafürt (Coronilla emereus L.). - Tilia 7: 254-260.

Bölöni, J. and Horváth, A. (1999): Törpe mandula (Amygdalus nana L.). - Tilia 7: 243-253.

Bölöni, J. and Nagy, J. (1999): Szirti gyöngyvessző (Spiraea media Fr. Schm.). - Tilia 7: $170-181$.

Börcsök, Z. (2004): Vezérfonal a Magyarországon előforduló szilek (Ulmus spp.) meghatározásához. [Guide to the identification of elm species existing in Hungary.] - Flora Pann. 2(2): 141-152. 
Brickel, C. D., Alexander, C., Cubey, J. J. David, J. C., Hoffman, M. H. A., Leslie, A. C., Malécot, V. and Xiaobai, Jin (eds) (2016): International code of nomenclature for cultivated plants, 9th edition. - Scripta Horticult. 18: 1-190.

Browicz, K. (1963): The genus Colutea L. A monograph. - Monogr. Bot. 14: 1-136.

Brummit, R. K. and Powell, C. E. (1992): Authors of plant names. A list of authors of scientific names of plants, with recommended standard form of their names including abbreviations. Royal Botanic Gardens, Kew, 732 pp.

Brunet, J., Zalapa, J. E., Pecori, F. and Santini, A. (2013): Hybridization and introgression between the exotic Siberian elm, Ulmus pumila, and the native Field elm, U. minor, in Italy. - Biol. Invasions 15: 2717-2730. https://doi.org/10.1007/s10530-013-0486-Z

Buttler, K. P. and Hand, R. (2008): Liste der Gefäßpflanzen Deutschlands. - Kochia 1: 1-107.

Buttler, K. P., May, R. and Metzing, D. (2018): Liste der Gerfäßpflanzen Deutschlands. Florensynopse und Synonyme. - BfN-Skripten 519, Bonn-Bad Godesberg, 286 pp. https://doi.org/10.19217/skr519

Carlton, J. T. (1996): Biological invasions and cryptogenic species. - Ecology 77(6): 16531655. https://doi.org/10.2307/2265767

Chen, J. Y. (2008): A taxonomic revision of Syringa L. (Oleaceae). - Cathaya 17-18: 1-170. https://doi.org/10.3724/SP.J.1002.2008.06177

Christenhusz, M. J. M., Reveal, J. L., Farjon, A., Gardner, M. F., Mill, R. R. and Chase, M. W. (2011): A new classification and linear sequence of extant gymnosperms. - Phytotaxa 19: 55-70. https://doi.org/10.11646/phytotaxa.19.1.3.

Christensen, K. I. and Jonsell, B. (2005): Proposal to conserve the name Salix fragilis with a conserved type (Salicaceae). - Taxon 54: 555-556. https://doi.org/10.2307/25065400

Czarna, A., Nowińska, R. and Gawrońska, B. (2013): Malus ×oxysepala (M. domestica Borkh. $\times$ M. sylvestris Mill.) - a new spontaneous apple hybrid. - Acta Soc. Bot. Pol. 82(2): 147-156. https://doi.org/10.5586/asbp.2013.016

Csapody, I. (2007): Őshonos-e a szelídgesztenye (Castanea sativa Mill.) hazánkban és Közép-, ill. Dél-Európában? [Is the sweet chestnut (Castanea sativa Mill.) native to Hungary and in Central and Southern Europe?] - Tilia 13: 105-116.

Csecserits, A. and Rédei, T. (2006): Arany ribiszke (Ribes aureum Pursh). - In: Botta-Dukát, Z. and Mihály, B. (eds): Biológiai inváziók Magyarországon. Özönnövények II. [Biological invasions in Hungary. Invasive plant species II.] A KvVM tanulmánykötetei 10, TermészetBúvár Alapítvány Kiadó, Budapest, pp. 27-35.

Csiszár, Á. and Bartha, D. (2008): Green ash (Fraxinus pennsylvanica Marsh.). - In: BottaDukát, Z. and Balogh, L. (eds): The most important invasive plants in Hungary. Institute of Ecology and Botany. Hungarian Academy of Sciences, Vácrátót, pp. 161-166.

Danihelka, J., Chrtek, Jr., J. and Kaplan, Z. (2012): Checklist of vascular plants of the Czech Republic. - Preslia 84: 647-811.

Di Pietro, R., Viscosi, V., Peruzzi, L. and Fortini, P. (2012): A review of the application of the name Quercus dalechampii. - Taxon 61: 1311-1316. https://doi.org/10.1002/tax.616012

Dickoré, W. B. and Kasperek, G. (2010): Species of Cotoneaster (Rosaceae, Maloideae) indigenous to, naturalising or commonly cultivated in Central Europe. - Willdenowia 40: 13-45. https://doi.org/10.3372/wi.40.40102

Dimopoulos, P., Raus, T., Bergmeier, E., Constantinidis, T., Iatrou, G., Kokkini, S., Strid, A. and Tzanoudakis, D. (2013): Vascular plants of Greece. An annotated checklist. Botanic Garden and Botanical Museum Berlin-Dahlem, Berlin \& Hellenic Botanical Society, Athens. - Englera 31: 1-372.

Dobay, P. (1999): Csikófark (Ephedra distachya L.). - Tilia 7: 7-15. 
Domokos, J. (1941): Mégegyszer: terem-e Cotoneaster integerrima az Ősmátrában? [Prevalence of Cotoneaster integerrima in Central Hungary.] - A m. kir. Kert. Akad. Közlem. 7: 47-51.

Euro+Med (2006 onwards): Euro+Med PlantBase - the information resource for Euro-Mediterranean plant diversity. http://ww2.bgbm.org/EuroPlusMed/ (accessed January to December 2020).

Facsar, G. (1981): A Rosa gallica L. magyarországi populációi. [Populations of Rosa gallica L. in Hungary.] - Publ. Univ. Horticult. 45: 121-129.

Facsar, G. (1982): Az elliptikus levelű rózsa (Rosa elliptica Tausch) Magyarországon. [Rose of ellipsoideal leaves (Rosa elliptica Tausch) in Hungary.] - Publ. Univ. Horticult. 46: 161-173.

Facsar, G. (1986): A zalai rózsa (Rosa zalana Wiesb.) Magyarországon. [The rose of Zala (Rosa zalana Wiesb.) in Hungary.] - Publ. Univ. Horticult. 50: 215-226.

Facsar, G. and Udvardy, L. (2008): Adventive grapevine species (Vitis-hybrids). - In: BottaDukát, Z. and Balogh, L. (eds): The most important invasive plants in Hungary. Institute of Ecology and Botany. Hungarian Academy of Sciences, Vácrátót, pp. 47-54.

Farjon, A. (2001): World checklist and bibliography of conifers, ed. 2. - The Royal Botanic Gardens, Kew, 309 pp.

Ferrer-Gallego, P. P., Ferrer-Gallego, R., Laguna, E. and Pipia, I. (2019): Proposal to conserve the name Vitis sylvestris C. C. Gmel. (Vitaceae) against V. sylvestris W. Bartram. - Taxon 68(2): 409-410. https://doi.org/10.1002/tax.12043

Forster, E. and Bölöni, J. (1999): Szirti fanyarka (Amelanchier ovalis Medik.). - Tilia 7: 233242.

Gaál, Gy. (1999): Keleti gyertyán (Carpinus orientalis Mill.). - Tilia 7: 37-42.

Gadó, Gy. P. (1999): Homoktövis (Hippophaë rhamnoides L.). - Tilia 7: 269-276.

Galasso, G., Conti, F., Peruzzi, L., Ardenghi, N. M. G., Banfi, E., Celesti-Grapow, L., Albano, A., Alessandrini, A., Bacchetta, G., Ballelli, S. et al. (2018): An updated checklist of the vascular flora alien to Italy. - Plant Biosyst. 152(3): 556-592. https://doi.org/10.1080/11263504.2018.1441197

Geerinck, D. (1979): Platanus $\times$ hispanica Mill. ex Münchh. cv. Acerifolia, nom correct du platane hybride ou à feuilles d'érable. - Bull. Jard. Bot. Nat. Belgique 49: 160-161. https://doi.org/10.2307/3667825

Gelderen, D. M., Jong, P. C. and Oterdoom, H. J. (1994): Maples of the World. - Timber Press, Portland \& London, $458 \mathrm{pp}$.

Gencsi, Z. (1999): Babérfüz (Salix pentandra L.). - Tilia 7: 55-59.

Gil, L., Fuentes-Utrilla, P., Soto, A., Cervera, M. T. and Collada, C. . (2004): English elm is a 2,000-year-old Roman clone. - Nature 431: 1053. https://doi.org/10.1038/4311053a

Gilli, Ch., Gutermann, W., Billensteiner, A. and Niklfeld, H. (2019): Liste der Gefäßpflanzen Österreichs. Version 1.0. - https://plantbiogeography.univie.ac.at/research/annotated-checklists/

Govaerts, R. and Frodin, D. G. (1998): World checklist and bibliography of Fagales (Betulaceae, Corylaceae, Fagaceae and Ticodendraceae). - The Royal Botanic Gardens, Kew, 456 pp.

Green, A. F., Ramsey, T. S. and Ramsey, J. (2011): Phylogeny and biogeography of Ivies (Hedera spp., Araliaceae), a polyploid complex of woody vines. - Syst. Bot. 36: 11141127. https://doi.org/10.1600/036364411X605100

Green, P. S. (1964): Registration of cultivar names in Ulmus. - Arnoldia 24(6-8): 41-80.

Grimm, G. W. and Denk, T. (2010): The reticulate origin of modern plane trees (Platanus, Platanaceae): a nuclear marker puzzle. - Taxon 59: 134-147. https://doi.org/10.1002/tax.591014

Gutermann, W. (2011): Notulae nomenclaturales 41-45. - Phyton (Horn) 51(1): 95-102.

Gyulai, F. (2001): Archeobotanika [Archaeobotany]. - Jószöveg Műhely Kiadó, Budapest, 221 pp. 
Gyulai, F. and Gyulai, G. (2009): Középkori szólókultúra és elózményei (magok és tanulságok). [Medieval viticulture and its antecedens (seeds and lessons learned).] - In: "ad vinum diserti...". Pannonhalmi Bencés Főapátság Levéltára \& Magyar Bortörténeti Társaság, Budapest, pp. 27-40.

Hegedűs, A., Kozma, P. and Németh, M. (1966): A szőlő Vitis vinifera L. Magyarország Kultúrflórája IV/1. - Akadémiai Kiadó, Budapest, 325 pp.

Holub, J. (1971): Fallopia Adans. 1763 instead of Bilderdykia Dum. 1827. - Folia Geobot. Phytotax. 6(2): 171-177. https://doi.org/10.1007/BF02851760

Horváth, F., Dobolyi, Z. K., Morschhauser, T., Lőkös, L., Karas, L. and Szerdahelyi, T. (1995): Flóra adatbázis 1.2. Taxon-lista és attribútum-állomány. [Flora database 1.2. Taxon list and attribute file.] - MTA Ökológiai és Botanikai Kutatóintézet, Vácrátót, 268 pp.

Hulják, P. (1999a): Vörös áfonya (Vaccinium vitis-idaea L.). - Tilia 7: 78-86.

Hulják, P. (1999b): Fekete lonc (Lonicera nigra L.). - Tilia 7: 277-280.

Hulják, P. and Kökény, I. (1999): Fűzlevelű gyöngyvessző (Spiraea salicifolia L.). - Tilia 7: 166-169.

Hulják, P. and Vojtkó, A. (2010): Havasi iszalag (Clematis alpina (L.) Mill.). - Tilia 15: 43-53.

ILDIS (2010 onwards): International Legume Database and Information Service. - http://www. ildis.org/ (accessed May to December 2020).

IPNI (2004 onwards): International Plant Names Index. - The Royal Botanic Gardens, Kew, Harvard University Herbaria \& Libraries and Australian National Botanic Gardens. Published on the Internet. http://www.ipni.org (accessed January to December 2020).

Jávorka, S. and Maliga, P. (eds) (1969): A gesztenye Castanea sativa Mill. Magyarország kultúrflórája VII/16. - Akadémiai Kiadó, Budapest, 123 pp.

Jeszenszky, Á. (ed.) (1972): Az eperfa Morus alba L. Magyarország kultúrflórája VII/11. Akadémiai Kiadó, Budapest, 103 pp.

Jirásek, V.(1964):Specioidund subspecioid.-Taxon13(7):226-232.https://doi.org/10.2307/1216691

Juhász, M. (2008): Black cherry (Prunus serotina Ehrh.). - In: Botta-Dukát, Z. and Balogh, L. (eds): The most important invasive plants in Hungary. Institute of Ecology and Botany. Hungarian Academy of Sciences, Vácrátót, pp. 77-84.

Juillerat, P., Bäumler, B., Bornand, C., Gygax, A., Jutzi, M., Möhl, A., Nyffeler, R., Sager, L., Santiago, H. and Eggenberg S. (2017): Checklist 2017 der Gefäßpflanzenflora der Schweiz I de la flore vasculaire de la Suisse / della flora vascolare della Svizzera. - Info Flora: Datenund Informationszentrum der Schweizer Flora / Centre de données et d'informations sur la flore de Suisse / Centro dei dati e d'informazioni sulla flora della Svizzera, 380 pp. https://doi.org/10.5167/uzh-165877

Kakiuchi, N., Mikage, M., Ickert-Bond, S., Maier-Stolte, M. and Freitag, H. (2011): A molecular phylogenetic study of the Ephedra distachya / E. sinica complex in Eurasia. - Willdenowia 41: 203-215. https://doi.org/10.3372/wi.41.41201

Kárpáti, Z. (1932): Rhamnus cathartica $\times$ saxatilis (Vorläufige Mitteilung). - Ann. Sabar.: Folia Mus. 1: 15.

Kárpáti, Z. (1934): Egy új Rhamnus-hybrid. [A new Rhamnus hybrid.] - Index Horti Bot. Univ. Budapest. 2: 1-10.

Kárpáti, Z. (1949): Hazai Cornus-aink vadontermő és kertészeti változatai. [Wild and horticultural taxa of Cornus species in Hungary.] - Agrártud. Egy. Kert-és Szőlőgazdaságtud. Kar. Közlem.13: 114-126.

Kárpáti, Z. (1952): A vesszős fagyal (Ligustrum vulgare L.) vadontermő és kerti alakjai. [Wild and garden forms of Ligustrum vulgare L.] - Kert. Kut. Int. Évk. 1: 103-114. 
Kárpáti, Z. (1958): Die Variabilität der Manna-Esche (Fraxinus ornus L.). - Acta Bot. Acad. Sci. Hung. 4: 93-112.

Kárpáti, Z. (1967): Taxonomische Betrachtungen am Genus Prunus. - Feddes Repert. 75(1-2): 47-53. https://doi.org/10.1002/fedr.19670750103

Kárpáti, Z. (1970): Eine kritisch-taxonomische Übersicht der in Europa wildwachsenden Eschen-Arten und deren Unterarten. - Feddes Repert. 81(1-5): 171-186. https://doi.org/10.1002/fedr.19700810114

Keller, J. (1999): Babérboroszlán (Daphne laureola L.). - Tilia 7: 97-110.

Kerényi-Nagy, V. (2010): A Történelmi Magyarország vadon termő és kultúrreliktum rózsáinak listája. [The checklist of the Historical Hungary's wild and kultur-relict roses.] - In: Penksza, K., Surányi, D., and Urbányi, B. (eds): Magyar Biológiai Társaság XXVIII. vándorgyưlés előadásainak összefoglalói. Magyar Biológiai Társaság, Budapest, pp. 65-73.

Kerényi-Nagy, V. (2010a): Piros áltermésű ritka galagonya fajok (Crataegus spp.). [Rare hawthorn species (Crataegus spp.) with red fruit.] - Tilia 15: 75-111. https://doi.org/10.2478/aslh-2014-0002

Kerényi-Nagy, V. (2010b): Ritka rózsafajok és hibridek (Rosa spp.). [Rare rose species and hybrids (Rosa spp.).] - Tilia 15: 191-270.

Kerényi-Nagy, V. (2011a): A szentendrei rózsa (Rosa sancti-andreae) nevezéktani és taxonómiai problémái. [Nomenclatural and taxonomical problems related to the Rosa sancti-andreae.] - Kanitzia 18: 13-28.

Kerényi-Nagy, V. (2011b): A zágrábi rózsa (Rosa zagrabiensis Vukotinovics et H. Braun) és a szentendrei rózsa (Rosa sancti-andreae Degen et Trautm.) taxonómiai helyzete és védelme. [The taxonomy status and protection of Rosa zagrabiensis Vukotinovics et H. Braun and Rosa sancti-andreae Degen et Trautm.] - In: Penksza, K. (ed.): VII. Kárpát-medencei Biológiai Szimpózium. Magyar Biológiai Társaság, Budapest, pp. 79-84.

Kerényi-Nagy, V. (2012a): A Történelmi Magyarország területén élő öshonos, idegenhonos és kultúr-reliktum rózsák kismonográfiája. [A small monograph of autochton, allochton and cultur-relict roses of Historical Hungary.] - Nyugat-magyarországi Egyetem Kiadó, Sopron, $430 \mathrm{pp}$.

Kerényi-Nagy, V. (2012b): A szentendrei rózsa (Rosa ciliato-petala Besser) nevezéktani, taxonómiai és növényföldrajzi helyzete. [Taxonomy, phytogeography and nomenclature of the Szentendre-Rose (Rosa ciliato-petala Besser).] - In: Kézdy, P. (ed.): Természetvédelem és kutatás a budai Sas-hegyen. [Nature conservation and research in Mt Sas-hegy.] Rosalia 8: 281-292.

Kerényi-Nagy, V. (2012c): Miért nem lehet kultúr-reliktum a szentendrei rózsa (Rosa ciliato-petala Besser)? [Why can not the Rosa ciliato-petala Besser a cultur-relict?] - Kanitzia 19: 59-70.

Kerényi-Nagy, V. (2014): Nomenclature, taxonomy and distribution of Crataegus lindmanii. - Acta Bot. Hung. 56(3-4): 331-341. https://doi.org/10.1556/ABot.56.2014.3-4.9

Kerényi-Nagy, V. (2015): A Kárpát-Pannon és Illír régió vadon termó galagonyáinak monográfiája. [A monograph of hawthorns of Carpat-Pannon and Illyr regions.] - Szent István Egyetem Mezőgazdaság- és Környezettudományi Kar, Gödöllő, 323 pp.

Kerényi-Nagy, V., Baranec, T. and Bartha, D. (2011): A Lindman-galagonya (Crataegus lindmanii Hrab.-Uhr.) és a szálkás egybibés galagonya (Crataegus curvisepala Lindm.) Magyarországon. - In: Penksza, K. (ed.): VII. Kárpát-medencei Biológiai Szimpózium. Magyar Biológiai Társaság, Budapest, pp. 91-96.

Kerényi-Nagy, V., Deák, T., Kósa, G. and Bartha, D. (2014): Genetic Studies of Selected "Black-Fruit" Hawthorns: Crataegus nigra Waldst. et Kit., C. pentagyna 
Waldst. et Kit. and C. chlorosarca Maxim. - Acta Silv. Lign. Hung. 10(1): 23-29. https://doi.org/10.2478/aslh-2014-0002

Kerényi-Nagy, V., Nagy, V. A. and Vers, J. (2011): Adatok a soktüskés rózsa (Rosa polyacantha (Borbás) H. Braun) elterjedéséhez és taxonómiájához. [Datas to the Rosa polyacantha (Borbás) H. Braun) localities and taxonomy.] - In: Penksza, K. (ed.): VII. Kárpát-medencei Biológiai Szimpózium. Magyar Biológiai Társaság, Budapest, pp. 145-152.

Kevey, B. and Bartha, D. (2010a): Jerikói lonc (Lonicera caprifolium L.). - Tilia 15: 112-138. Kevey, B. and Bartha, D. (2010b): Szúrós csodabogyó (Ruscus aculeatus L.). - Tilia 15: 271-301. Kevey, B. and Bartha, D. (2010c): Ligeti szőlő (Vitis sylvestris Gmel.). - Tilia 15: 342-369. Kézdy, P. (1999): Lisztesfonákú berkenyék (Sorbus spp.). - Tilia 7: 182-192.

Kézdy, P. and Tímár, G. (1999): Henye boroszlán (Daphne cneorum L.). - Tilia 7: 111-125. Király, G. (1999a): Köszméte (Ribes uva-crispa L.). - Tilia 7: 126-131.

Király, G. (1999b): Vörös ribiszke (Ribes rubrum L. agg.). - Tilia 7: 132-143.

Király, G. (2016): Taxonomical and chorological notes 3. (31) Carpinus orientalis Mill. (Betulaceae).-Studiabot.hung. 47(2):348-350.https://doi.org/10.17110/StudBot.2016.47.2.345

Király, G. and Bölöni, J. (2004): A feketedő füz (Salix myrsinifolia Salisb.) újrafelfedezése Magyarországon. [Rediscovery of Salix myrsinifolia Salisb. in Hungary.] - Flora Pann. 2(2): 103-117.

Király, G. and Kevey, B. (1999a): Hamvas éger (Alnus incana (L.) Moench). - Tilia 7: 24-36. Király, G. and Kevey, B. (1999b): Fekete ribiszke (Ribes nigrum L.). - Tilia 7: 154-162.

Király, G. and Király, A. (2010): Molyhos nyír (Betula pubescens Ehrh.). - Tilia 15: 21-42.

Király, G. and Király, A. (2018): Adatok és kiegészítések a magyar flóra ismeretéhez III. [Chorological, ecological and taxonomic notes on the vascular flora of Hungary III.] - Bot. Közlem. 105(1): 27-96. [spec. Myricaria pp. 49-52.]

https://doi.org/10.17716/BotKozlem.2018.105.1.27

Király, G., Bölöni, J., Hulják, P. and Vojtkó, A. (1999): Havasi ribiszke (Ribes alpinum L.). - Tilia 7: 144-151.

Korda, M. (2010a): Csermelyciprus (Myricaria germanica (L.) Desv.). - Tilia 15: 139-148.

Korda, M. (2010b): Parti füz (Salix elaeagnos Scop.) - Tilia 15: 302-315.

Korda, M. (2012): Ecetszömörce (Rhus typhina L.). - In: Csiszár, Á. (ed.): Inváziós növényfajok Magyarországon. [Invasive alien plant species in Hungary.] Nyugat-magyarországi Egyetem Kiadó, Sopron, pp. 139-143.

Korda, M. (2014): Újabb adat a magyar adventív flóra ismeretéhez: az Acer opalus Mill. subsp. obtusatum (Waldst. et Kit. ex Willd.) Gams 1925 Magyarországon. [New data on the Hungarian adventive flora: Acer opalus Mill. subsp. obtusatum (Waldst. et Kit. ex Willd.) Gams 1925 in Hungary.] - Kitaibelia 19(2): 229-238.

Kučera, P. (2018): New name for Central Europaean oak formerly labelled as Quercus dalechampii. - Biologia 73: 313-317. https://doi.org/10.2478/s11756-018-0048-z

Kuzovkina, Y. A. (2015): Checklist for cultivars of Salix L. (willow), 1st version. - International Salix Cultivar Registration Authority, FAO-International Poplar Commission, 163 pp. https://doi.org/10.21273/HORTSCI.50.11.1608

Lambdon, P. W., Pyšek, P., Basnou, C., Hejda, M., Arianoutsou, M., Essl, F., Jarošík, V., Pergl, J., Winter, M., Anastasiu, P., Andriopoulos, P., Bazos, I., Brundu, G., CelestiGrapow, L., Chassot, P., Delipetrou, P., Josefsson, M., Kark, S., Klotz, S., Kokkoris, Y., Kühn, I., Marchante, H., Perglová, I., Pino, J., Vilà, M., Zikos, A., Roy, D. and Hulme, P. E. (2008): Alien flora of Europe: species diversity, temporal trends, geographical patterns and research needs. - Preslia 80: 101-149.

Lavin, M. and Sousa, M. (1995): Phylogenetic systematics and biogeography of the tribe Robinieae (Leguminosae). - Syst. Bot. Monogr. 45: 1-165. https://doi.org/10.2307/25027850 
Lelkes, A. (1999): Lónyelvű csodabogyó (Ruscus hypoglossum L.). - Tilia 7: 281-285.

Lepší, M., Lepší, P., Koutecký, P., Bíla, J. and Vít, P. (2015): Taxonomic revision of Sorbus subgenus Aria occurring in the Czech Republic. - Preslia 87: 109-162.

Lewis, G., Schrire, B., Mackinder, B. and Lock, M. (eds) (2005): Legumes of the World. - Royal Botanic Gardens, Kew, 577 pp. https://doi.org/10.1017/S0960428606190198

Lim, G. S., Carvalho, M., Stuber, S. M., Gunner, S. T. and Reveal, J. L. (2013): A reconsideration of the typification of Rafinesque generic names allied to Salix L. - Rhodora 115: 170-190. https://doi.org/10.3119/12-11

Manos, P. S. and Stone, D. E. (2001): Evolution, phylogeny, and systematics of the Juglandaceae. - Ann. Missouri Bot. Gard. 88(2): 231-239.

Manton, I. (1958): The concept of aggregate species. - Uppsala Univ. Arsskr. 1958/6: 104-112.

Marhold, K. and Hindák, F. (eds) (1998): Zoznam nižších a vyšších rastlín Slovenska. [Checklist of non-vascular and vascular plants of Slovakia.] - VEDA, Bratislava, 687 pp.

Mátyás, V. (1970a): Taxa nova Quercuum Hungariae. - Acta Bot. Hung. 16: 329-361.

Mátyás, V. (1970b): Einführung in die Kenntnis der Eichenarten Ungarns. [Contributions to the knowledge of oaks in Hungary.] - Erd. Kut. 66(2): 61-68.

Mátyás, V. (1970c): A cser alakváltozatossága Magyarországon. [The form variability of Turkey oak in Hungary.] - Erd. Kut. 66(1): 179-211.

Mátyás, V. (1971a): A magyarországi kocsánytalan tölgyfajok alakkörének kritikai elemzése. [A critical analysis of intraspecific taxa of sessile oak in Hungary.] - Erd. Kut. 67(1): 43-96.

Mátyás, V. (1971b): Short taxonomic review of the oaks of Hungary. - Erd. Kut. 67(2): 55-68.

Mátyás, V. (1972): A szlavón tölgy (Quercus robur ssp. slavonica (Gáy.) Máty.) erdészeti jelentősége Magyarországon. [Significance of the Slavonian oak (Quercus robur ssp. slavonica (Gáy.) Máty.) in forestry in Hungary.] - Erd. Kut. 68(1): 63-77.

Mátyás, V. (1973a): Magyarország kocsányos tölgyeinek alakjai. [Pedunculate oak forms in Hungary.] - Erd. Kut. 69(1): 223-249.

Mátyás, V. (1973b): The Italian pubescent oak (Quercus virgiliana Ten. 1836) in the Carpathian basin and its outer fringes. - Erd. Kut. 69(2): 47-91.

Mátyás, V. (1975): Magyarország molyhos tölgyei. [Pubescent oaks of Hungary.] - Erd. Kut. 71(1): 125-147.

McAllister, H. A. and Marshall, R. H. (2017): Hedera: the complete guide. - The Royal Horticultural Society, London, $401 \mathrm{pp}$.

McVaugh, R. (1951): A revision of the North American black cherries (Prunus serotina Ehrh., and relatives). - Brittonia 7(4): 279-315. https://doi.org/10.2307/2804698

Mikolás, V., Sennikov, A., Beech, E. and Rivers, M. C. (2017): Sorbus thaiszii. - The IUCN Red List of Threatened Species 2017: e.T95414735A95414738.

Mirek, Z., Piękoś-Mirkowa, H., Zając, A. and Zając, M. (2002): Flowering plants and pteridophytes of Poland. A checklist. - In: Mirek, Z. (ed.): Biodiversity of Poland 1. W. Szafer Institute of Botany, Polish Academy of Sciences, Kraków, 442 pp.

Molnár, V. A., Löki, V., Máté, A., Molnár, A., Takács, A., Nagy, T., Lovas-Kiss, Á., Sramkó, G. and Tökölyi, J. (2017): The occurrence of Spiraea crenata and other rare steppe plants in Pannonian graveyards. - Biologia 72: 500-509. https://doi.org/10.1515/biolog-2017-0060

Mosyakin, S. L. and Fedoronchuk, M. M. (1999): Vascular plants of Ukraine. A nomenclatural checklist. - National Academy of Sciences of Ukraine M. G. Kholodny Institute of Botany, Kiev, 345 pp. https://doi.org/10.13140/2.1.2985.0409

Nagy, J. Gy., Zsinka, B., Verebélyi, V., Zorkóczy, O. K. and Tyler, T. (2017): A Vaccinium microcarpum (Turcz. ex Rupr.) Schmalh. Magyarországon. [Vaccinium mi- 
crocarpum (Turcz. ex Rupr.) Schmalh. in Hungary.] - Kitaibelia 22(1): 71-76. https://doi.org/10.17542/kit.22.71

Nagy, L. (1999): Kövi benge (Rhamnus saxatilis Jacq.). - Tilia 7: 261-268.

Nelson, E. C. (1980): What is the correct name for the Dunkeld Hybrid Larch (Larix decidua $\times$ L. leptolepis)? - Irish Forestry 37: 112-118.

Németh, Cs. (2006): Hibrid eredetü, bennszülött Sorbus taxonok elterjedése a Vértesben és környékén. [Distribution of hybridogenous, endemic Sorbus taxa in Vértes Mountains, Central Hungary.] - Flora Pann. 4: 17-33.

Németh, Cs. (2007): Új berkenye kisfaj a magyar flórában: Sorbus tobani Németh. [Sorbus tobani Németh, a new hybridogenous species of the genus Sorbus L. emend. Cr. from the Bakony Mountains, Hungary.] - Flora Pann. 5: 175-186.

Németh, Cs. (2009): Új berkenye (Sorbus) kisfajok a Vértesből. [Three new Sorbus microspecies from the Vértes Mountains (W-Hungary).] - Kitaibelia 14(1): 89-103.

Németh, Cs. (2010): Taxonomic revision, typification and validation of Sorbus (Rosaceae) taxa in the herbarium Carpato-Pannonicum in Budapest I. - Acta Bot. Hung. 52(3-4): 377-397. https://doi.org/10.1556/ABot.52.2010.3-4.14

Németh, Cs. (2012): Two new Sorbus (Rosaceae) species from the Bakony Mts, Hungary. Acta Bot. Hung. 54(1-2): 131-144. https://doi.org/10.1556/ABot.54.2012.1-2.15

Németh, Cs. (2013): Hibrid eredetü, bennszülött Sorbus aria s. 1. × Sorbus torminalis taxonok (nothosubgenus Tormaria, S. latifolia agg.) elterjedése a Bakonyban. [Distribution of hybridogenous endemic Sorbus aria s. 1. × Sorbus torminalis taxa (nothosubgenus Tormaria, S. latifolia agg.) in the Bakony Mts, Hungary.] - Kitaibelia 18(1-2): 89-104.

Németh, Cs. (2015a): Sorbus pelsoensis (Sorbus subgenus Tormaria), a new species from the surroundings of Lake Balaton, Hungary. - Studia bot. hung. 46(1): 49-60. https://doi.org/10.17110/StudBot.2015.46.1.49

Németh, Cs. (2015b): Taxonomical revision of Sorbus pseudosemiincisa (Rosaceae), a stenoendemic whitebeam from the Vértes Mts (Hungary), with the description of a new species, Sorbus pyricarpa. - Studia bot. hung. 46(2): 157-174. https://doi.org/10.17110/StudBot.2015.46.2.157

Németh, Cs., Barabits, E. and Bílá, J. (2016): New Sorbus subg. Tormaria (S. latifolia agg.) species from southwestern part of the Transdanubian Mountain Range (Keszthely Mts, Hungary). - Studia bot. hung. 47(2): 297-318. https://doi.org/10.17110/StudBot.2016.47.2.297

Niketić, M. and Tomović, G. (2018): An annotated checklist of vascular flora of Serbia 1. - Serbian Academy of Sciences and Arts, Belgrade, pp. 101-180. https://doi.org/10.5937/bnhmb1811101N

Nikolić, T. (ed.) (1994, 1997, 2000): Flora Croatica. Index Florae Croaticae, Pars 1-3. - Nat. Croat. 3(Suppl. 2): 1-116, 6(Suppl. 1): 1-232, 9(Suppl. 1): 1-324.

Oprea, A. (2005): Lista critică a plantelor vasculare din România. - Univ. "Alexandru Ioan Cuza", Iaşi, 668 pp.

Pennington, R. T., Stirton, C. H. and Schrire, B. D. (2005): Tribe Sophoreae. - In: Lewis, G., Schrire, B. D., Mackinder, B. and Lock, M. (eds): Legumes of the World. Royal Botanic Gardens, Kew, pp. 227-249.

Pénzes, A. (1941): Egy uj Lycium-fajról (Lycium diószegii Pénzes nova spec.). - Borbásia 3(8-10): 136-139.

Pénzes, A. (1950): Kökény-szilva (Prunus) tanulmányok. (Prunus sect. Prunophora). [Study on the genus Prunus.] - Agrártud. Egy. Kert. Kar. Közlem. 13: 66-74.

Pénzes, A. (1958): Data to the ecology and taxonomy of the Cotinus genus. - Acta Bot. Sinica 7(3): 165-169. 
Pigott, C. D., Sell, P. (1995): Nomenclature of the European species of Tilia. I. Tilia europaea L. - Kew Bull. 50: 135-139. https://doi.org/10.2307/4114618

Pilotti, M., Brunetti, A., Tizzani, L. and Marani, O. (2009): Platanus acerifolia genotypes surviving in inoculation with Ceratocystis platani (the agent of canker stain): first screening and molecular characterization. - Euphytica 169: 1-17. https://doi.org/10.1007/s10681-009-9884-9

POWO (2021): Plants of the World Online. - Facilitated by the Royal Botanic Gardens, Kew. Published on the Internet; http://www.plantsoftheworldonline.org/ (accessed January to December 2020).

Priszter, Sz. (1985): Catalogus cormophytorum Hungariae. - In: Priszter, Sz. (ed.): Synopsis systematico-geobotanica florae vegetationisque Hungariae VII. Akadémiai Kiadó, Budapest, pp. 120-254.

Priszter, Sz. (2004): A lícium (Lycium barbarum L., syn.: L. halimifolium Mill.) magyarországi története. [History of spiny boxthorn in Hungary.] - Kitaibelia 9(1): 25-30.

Priszter, Sz. (ed) (1990): A húsos som Cornus mas L. Magyarország kultúrflórája VII/16. Akadémiai Kiadó, Budapest, 114 pp.

Priszter, Sz. and Borhidi, A. (1967): A Mecseki flórajárás (Sopianicum) flórájához I. [To the flora of the Mecsek (Sopianicum, S-Hungary).] - Bot. Közlem. 54(3): 149-164. (Ruscus spec. pp. 156-157.

Pyšek, P., Danihelka, J., Sádlo, J., Chrtek, J. Jr., Chytrý, M., Jarošík, V., Kaplan, Z., Krahulec, F., Moravcová, L., Pergl, J., Štajerová, K. and Tichý, L. (2012): Catalogue of alien plants of the Czech Republic (2nd edition): checklist update, taxonomic diversity and invasion patterns. - Preslia 84: 155-255.

Qian, G.-Z., Liu, L.-F. and Geng-Guo Tang, G.-G. (2010): Proposal to conserve the name Malus domestica against M. pumila, M. communis, M. frutescens, and Pyrus dioica (Rosaceae). - Taxon 59(2): 650-652. https://doi.org/10.1002/tax.592038

Qin, X. K. (2009): A new system of Ligustrum (Oleaceae). - Acta Bot. Yunnan. 31: 97-116. https://doi.org/10.3724 SP.J.1143.2009.08131

Richens, R. H. (1977): New designations in Ulmus minor Mill. - Taxon 26(5/6): 583-584.

Robinson, J. P., Harris, S. A. and Juniper, B. E. (2001): Taxonomy of the genus Malus Mill. (Rosaceae) with emphasis on the cultivated apple, Malus domestica Borkh. - Plant Syst. Evol. 226(1-2): 35-58. https://doi.org/10.1007/ s006060170072

Schmidt, P. A. (2017): Wild species and hybrids of Crataegus L. (Rosaceae) in W-, N- and Middle Europe. - Belg. Dendrol. Belge pp. 67-82.

Sennikov, A. N. and Kurtto, A. (2017): A phylogenetic checklist of Sorbus s. 1. (Rosaceae) in Europe. - Mem. Soc. Fauna Flora Fennica 93: 1-78.

Sennikov, A. N. and Somlyay, L. (2011): Atlas Florae Europaeae notes 17: Typification of Cotoneaster tomentosus (Rosaceae) and its synonyms. - Taxon 60(2): 579-584. https:// doi.org/10.1002/tax.602026

Skvortsov, A. K. (2010): Taxonomical synopsis of the genus Populus L. in East Europe, North and Central Asia. - Byull. Glavn. Bot. Sada 196: 62-73.

Somlyay, L. and Sennikov, A. N. (2014): Atlas Florae Europaeae Notes 23. The typification revised taxonomic circumscription of Sorbus bakonyensis (Rosaceae), with a description of Sorbus udvardyana, a new apomictic species endemic to Hungary. - Phytotaxa 164(4): 265-275. https://doi.org/10.11646/phytotaxa.164.4.5

Somlyay, L. and Sennikov, A. N. (2015): Atlas Florae Europaeae Notes 24. Taxonomic interpretation - typification of Sorbus pannonica (Rosaceae), a presumed intermediate between S. aria - S. graeca from Hungary. - Ann. Bot. Fenn. 52(3-4): 274-287. https:// doi.org/10.5735/085.052.0322 
Somlyay, L. and Sennikov, A. N. (2016): Atlas Florae Europaeae Notes 25. Taxonomic circumscription - nomenclature of Sorbus danubialis (Rosaceae). - Nord. J. Bot. 34: 7586. https://doi.org/10.1111/njb.00914

Somlyay, L., Lisztes-Szabó, Zs. and Sennikov, A. N. (2016a): Atlas Florae Europaeae Notes 28. Disentangling the taxonomic circumscription of Sorbus subdanubialis (Rosaceae). - Ann. Bot. Fenn. 53: 345-360. https://doi.org/10.5735/085.053.0607

Somlyay, L., Lisztes-Szabó, Zs. and Sennikov, A. N. (2016b): Atlas Florae Europaeae Notes 29. Two new species of Sorbus (Rosaceae) endemic to Hungary, previously confused with S. subdanubialis. - Ann. Bot. Fenn. 53: 361-372. https://doi.org/10.5735/085.053.0608

Somlyay, L., Lisztes-Szabó, Zs., Vojtkó, A. and Sennikov, A. N. (2017): Atlas Florae Europaeae notes 31. Sorbus javorkana (Rosaceae), a redescribed apomictic species from the Gömör-Torna (Gemer-Turňa) Karst in Hungary - Slovakia. - Ann. Bot. Fenn. 54: 229-237. https://doi.org/10.5735/085.054.0605

Soó, R. (1933): Referate. - Bot. Centralbl. 23: 119-120.

Soó, R. (1964-1973): Synopsis systematico-geobotanica florae vegetationisque Hungariae I-V. Akadémiai Kiadó, Budapest, 589 pp., 655 pp., 506 pp., 614 pp., 724 pp.

Soó, R. (1980): Conspectus florae vegetationisque Hungariae. - In: Soó, R.: Synopsis systematico-geobotanica florae vegetationisque Hungariae VI. Akadémiai Kiadó, Budapest, pp. 261-524.

Soó, R. and Simon, T. (1960): Bemerkungen über Südosteuropäischen Fraxinus- und Dianthus-Arten. - Acta Bot. Acad. Sci. Hung. 6(1-2): 143-153.

Sousa, S. M. and Rudd, V. E. (1993): Revision del genero Styphnolobium. - Ann. Missouri Bot. Gard. 80: 270-283. https://doi.org/10.2307/2399827

Stace, C. A., Preston, C. D. and Pearman, D. A. (2016): Hybrid flora of the British Isles. - Botanical Society of Britain and Ireland, Bristol, 501 pp. https://doi.org/10.1111/boj.12455

Stevens, P. F. (2001 onwards): Angiosperm Phylogeny Website. - Version 11, 2011 [and more or less continuously updated since]. http://www.mobot.org/MOBOT/research/APweb (accessed January to December 2020).

Surányi, D. (2014): A birs elterjedése Magyarországon. [Dissemination of quince in Hungary.] - Tájökol. Lapok 12(1): 221-243.

Surányi, D. (ed.) (2011): A sárgabarack Armeniaca vulgaris Lam. Magyarország kultúrflórája II/9. - Szent István Egyetemi Kiadó, Gödöllő, 303 pp.

Surányi, D. (ed.) (2019): A házi szilva Prunus domestica L. és rokonfajai. Magyarország kultúrflórája II/13. - Szent István Egyetemi Kiadó, Gödöllő, 416 pp.

Szász, S. (2006): Vadszőlőfajok (Parthenocissus spp.). - In: Botta-Dukát, Z. and Mihály, B. (eds): Biológiai inváziók Magyarországon. Özönnövények II. [Biological invasions in Hungary. Invasive plant species II.] A KvVM tanulmánykötetei 10, TermészetBúvár Alapítvány Kiadó, Budapest, pp. 131-142.

Szigetvári, Cs. and Tóth, T. (2008): False indigo (Amorpha fruticosa L.). - In: Botta-Dukát, Z. and Balogh, L. (eds): The most important invasive plants in Hungary. Institute of Ecology and Botany. Hungarian Academy of Sciences, Vácrátót, pp. 55-61.

Szmorad, F. (2010): Fürtös bodza (Sambucus racemosa L.). - Tilia 15: 316-341.

Szmorad, F. and Barabás, S. (1999): Tőzegáfonya (Vaccinium oxycoccos L.). - Tilia 7: 69-77.

Tavaud, M., Zanetto, A., David, J. L., Laigret, F. and Dirlewanger, E. (2004): Genetic relationships between diploid and allotetraploid cherry species (Prunus avium, Prunus $\times$ gondouinii and Prunus cerasus). - Heredity 93: 631-638.

Terpó, A. (1962a): A Ribes vulgare Lam. magyarországi előfordulásáról. [On the occurrence of Ribes vulgare Lam. in Hungary.] - Kert. Szől. Föisk. Évk. 26: 123-143. 
Terpó, A. (1962b): Adatok a hazai vadontermő Vitis-ek ismeretéhez. [Data for the knowledge of the wild Vitis taxa in Hungary.] - Kert. Szól. Föisk. Évk. 26: 147-161.

Terpó, A. (1968): A sajmeggy (Cerasus mahaleb (L.) Mill.) taxonómiai problémái és a gyakorlat. [Taxonomic problems of Cerasus mahaleb (L.) Mill. and the practice.] - Szólóés Gyümölcstermesztés 4: 103-131.

Terpó, A. (1988): A pannóniai területek természetes előfordulású szőlő (Vitis) populációinak eredete, taxonómiája és gyakorlati jelentösége. [Origin, taxonomy and practical significance of naturally occurring grape (Vitis) populations in the Pannonian areas.] - MTA Doktori Értekezés tézisei [HAS Doctoral Theses], Budapest, 22 pp.

Terpó, A. (1992): Pyrus taxa in Hungary and their practical importance. - Thaiszia 2: 41-57. Terpó, A. and Grúsz, E. (1976): A Magyarországon termesztett Mahonia állomány rendszertani vizsgálata. [Systematic study of the Mahonia taxa grown in Hungary.] - Publ. Univ. Horticult. Industr. Aliment. 40: 333-350.

Terpó, A., Zając, M. and Zając, A. (1999): Provisional list of Hungarian archaeophytes. Thaiszia 9: 41-47.

Teski, A., Kerényi-Nagy, V., Penksza, K., Penksza, P. and Wichmann, B. (2017): A Rosa × belgradensis Pancic származásának igazolása morfometriai módszerrel. [Verification of the origin of Rosa $\times$ belgradensis Pancic by morphometric method.] - In: Kerényi-Nagy, V. et al. (eds): II. Rózsa- és galagonyakutatás a Kárpát-medencében. Konferencia-kötet. [2nd Rose- and hawthorn research in Carpathian Basin. Proceedings-book.] Szent István Egyetem Egyetemi Kiadó, Gödöllő, pp. 282-283.

Tímár, G. (1999a): Tiszafa (Taxus baccata L.). - Tilia 7: 16-23.

Tímár, G. (1999b): Farkasboroszlán (Daphne mezereum L.). - Tilia 7: 89-96.

TPL (2013 onwards): The Plant List. A working list of all plant species. - Published on the Internet; http://www.theplantlist.org (accessed January to December 2020).

Trpin, D. and Vreš, B. (1995): Register flore Slovenije. Praprotnice in cvetnice. [Register of the flora of Slovenia. Ferns and vascular plants.] - Znanstvenoraziskovalni center SAZU, Ljubljana, $143 \mathrm{pp}$.

Turland, N. J., Wiersema, J. H., Barrie, F. R., Greuter, W., Hawksworth, D. L., Herendeen, P. S., Knapp, S., Kusber, W.-H., Li, D.-Z., Marhold, K., May, T. W., McNeill, J., Monro, A. M., Prado, J., Price, M. J. and Smith, G. F. (eds) (2018): International Code of Nomenclature for algae, fungi, and plants (Shenzhen Code) adopted by the Nineteenth International Botanical Congress Shenzhen, China, July 2017. - Regnum Vegetabile 159. Glashütten: Koeltz Botanical Books. https://doi.org/10.12705/Code.2018.

Turland, N. J., Wiersema, J. H., Monro, A. M., Deng, Y.-F. and Zhang, L. (2017): XIX International Botanical Congress: Report of Congress action on nomenclature proposals. - Taxon 66(5): 1234-1245. https://doi.org/10.12705/665.16

Tuzson, J. (1911): A Daphne génusz Cneorum subsectiójáról. [De subsectione “Cneorum" generis Daphnes.] - Bot. Közlem. 10: 135-152.

Udvardy, L. (2008a): Boxelder (Acer negundo L.). - In: Botta-Dukát, Z. and Balogh, L. (eds): The most important invasive plants in Hungary. Institute of Ecology and Botany. Hungarian Academy of Sciences, Vácrátót, pp. 115-120.

Udvardy, L. (2008b): Tree of heaven (Ailanthus altissima (Mill.) Swingle). - In: Botta-Dukát, Z. and Balogh, L. (eds): The most important invasive plants in Hungary. Institute of Ecology and Botany. Hungarian Academy of Sciences, Vácrátót, pp. 121-127.

Udvardy, L. and Bényeiné Himmer, M. (1999): Irish ivy (Hedera hibernica (Kirchner) Bean) as a woody evergreen weed. - Publ. Univ. Horticult. Industr. Aliment. 59: 161-164.

Ufimov, R. A. and Dickinson, T. A. (2020): Infrageneric nomenclature adjustments in Crataegus L. (Maleae, Rosaceae). - Phytologia 102(3): 177-199. 
Varga, I., Poczai, P., Tiborcz, V., Aranyi, R. N., Baltazár, T., Bartha, D., Pejchal, M. and Hyvönen, J. (2014): Changes in the distribution of the European mistletoe (Viscum album) in Hungary. - Folia Geobot. 49: 559-577. https://doi.org/10.1007/s12224-014-9193-5

Vidéki, R. and Virók, V. (eds) (2004): Magyarország edényes flórájának katalógusa. [Catalog of the vascular flora of Hungary.] - Saját kiadás [Own edition], Sopron-Aggtelek, 185 pp.

Vigouroux, A., Besnard, G., Sossey-Alaoui, K., Tersac, M. and Bervillé, A. (1997): Hybrid origin of Platanus acerifolia confirmed and the one of P. densicoma revealed with genetic markers: consequences. - Acta Bot. Gallica 144(2): 243-251. https://doi.org/10.1080/12538078.1997.10515772

Wallander, E. (2008): Systematics of Fraxinus (Oleaceae) and evolution of Dioecy. - Plant Syst. Evol. 273: 25-49. https://doi.org/10.1007/s00606-008-0005-3

Wannan, B. S. (2006): Analysis of generic relationships in Anacardiaceae. - Blumea 51: 165195. https://doi.org/10.3767/000651906X6224277

WCSP (2021): World checklist of selected plant families. - Facilitated by the Royal Botanic Gardens, Kew. Published on the Internet; http://wcsp.science.kew.org/ (accessed January to December 2020).

Wiersema, J. H., Turland, N. J., Barrie, F. R., Greuter, W., Hawksworth, D. L., Herendeen, P. S., Knapp, S., Kusber, W.-H., Li, D.-Z., Marhold, K., May, T. W., McNeill, J., Monro, A. M., Prado, J., Price, M. J. and Smith, G. F. (eds) (2018+ continuously updated): International Code of Nomenclature for algae, fungi, and plants (Shenzhen Code) adopted by the Nineteenth International Botanical Congress Shenzhen, China, July 2017: Appendices I-VII. - http://naturalhistory2.si.edu/botany/codes-proposals/ [accessed January to December 2020]

Wisskirchen, R. and Haeupler, H. (1998): Standardliste der Farn-und Blütenpflanzen Deutschlands. - Verlag Eugen Ulmer, Stuttgart, 765 pp. https://doi.org/10.1002/fedr.19991100520

Yang, W. J., Li, L. Q. and Xie, L. (2009): A revision of Clematis sect. Atragene (Ranunculaceae). - J. Syst. Evol. 47: 552-580. https://doi.org/10.1111/j.1759-6831.2009.00057.x

Zagyvai, G. (2012): Közönséges orgona (Syringa vulgaris L.). - In: Csiszár, Á. (ed.): Inváziós növényfajok Magyarországon. [Invasive alien plant species in Hungary.] Nyugatmagyarországi Egyetem Kiadó, Sopron, pp. 201-205.

Open Access statement. This is an open-access article distributed under the terms of the Creative Commons Attribution 4.0 International License (https://creativecommons.org/ licenses/by/4.0/), which permits unrestricted use, distribution, and reproduction in any medium, provided the original author and source are credited, a link to the CC License is provided, and changes - if any - are indicated. (SID_1) 


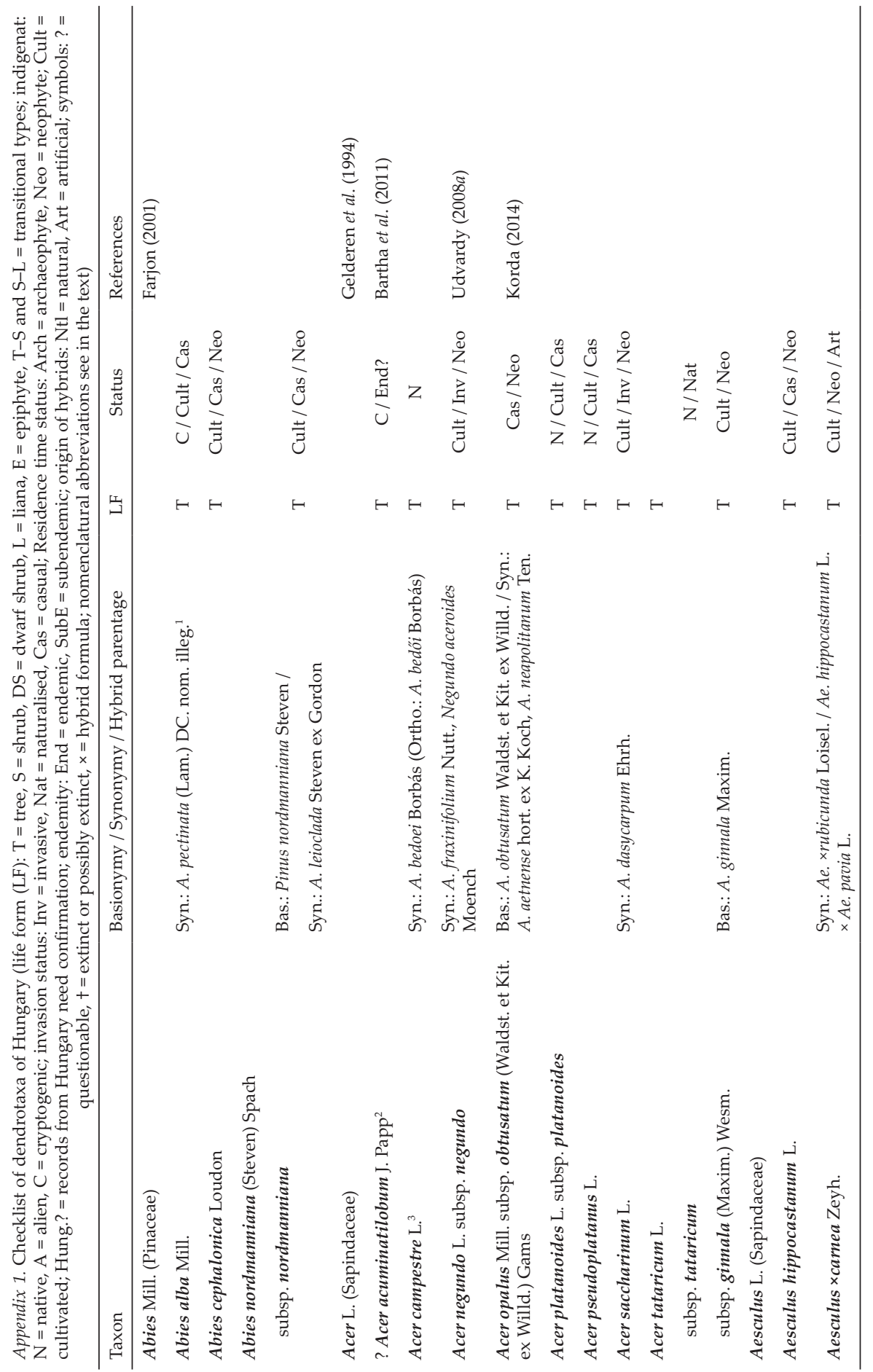




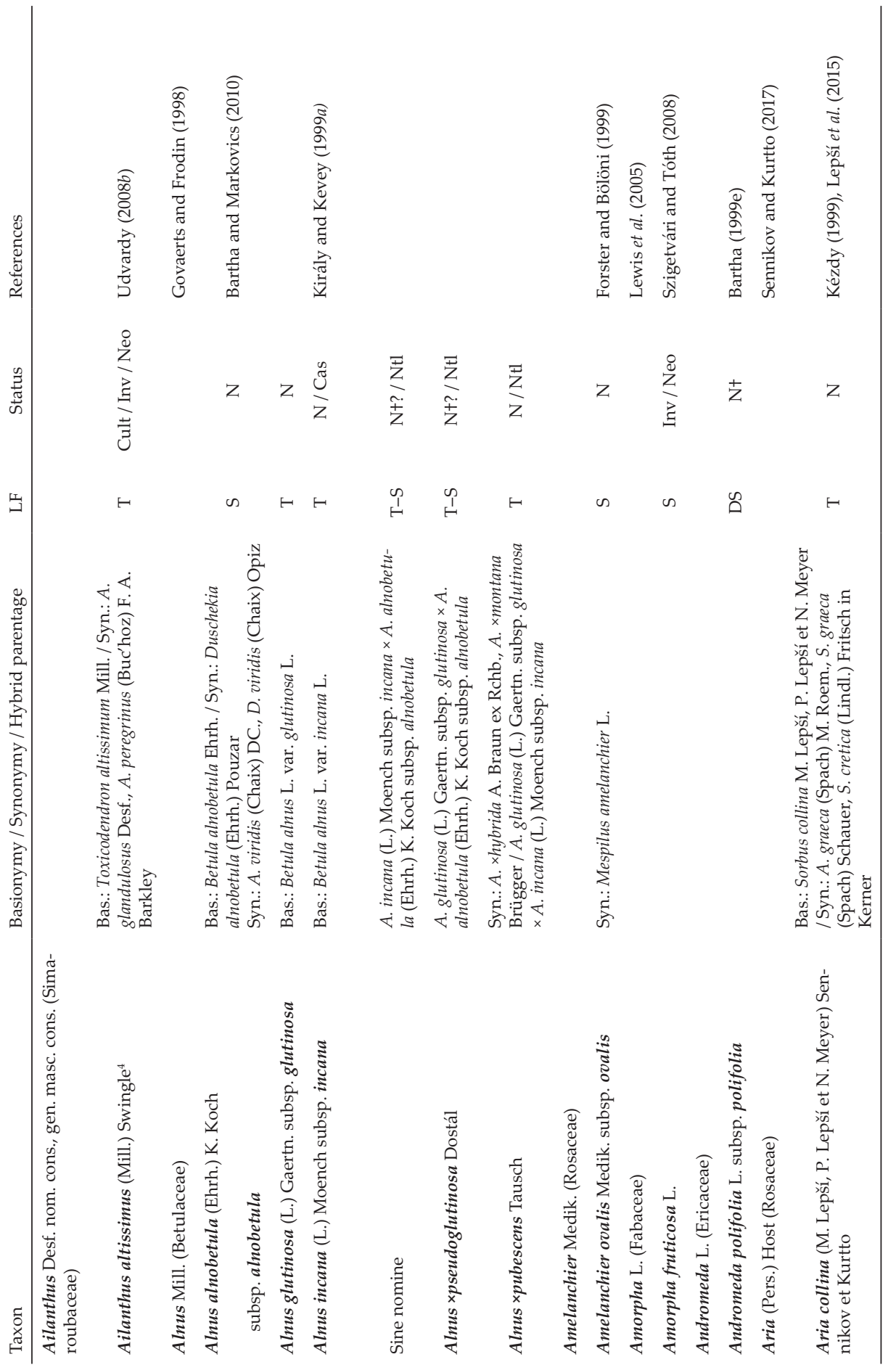




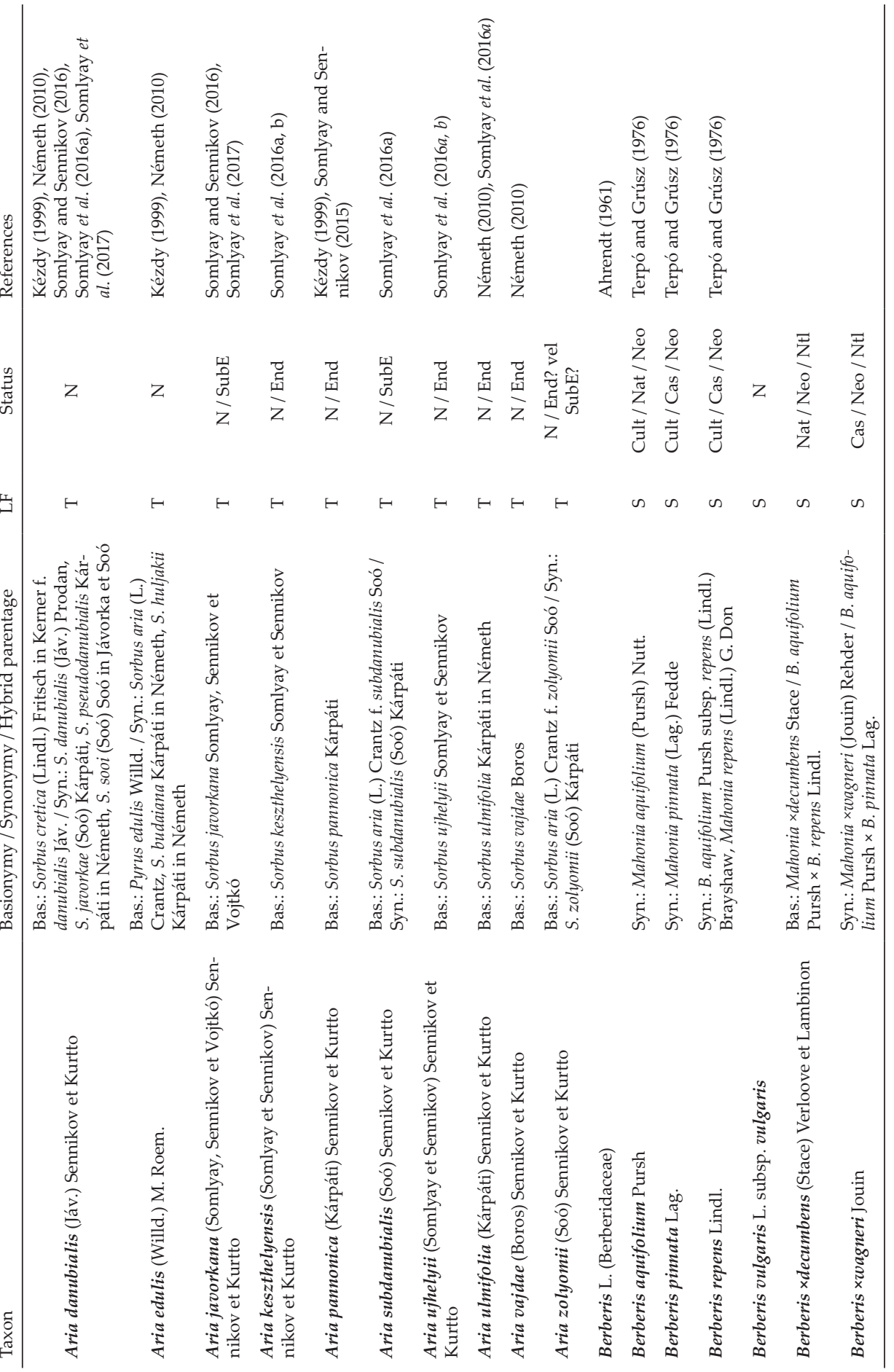




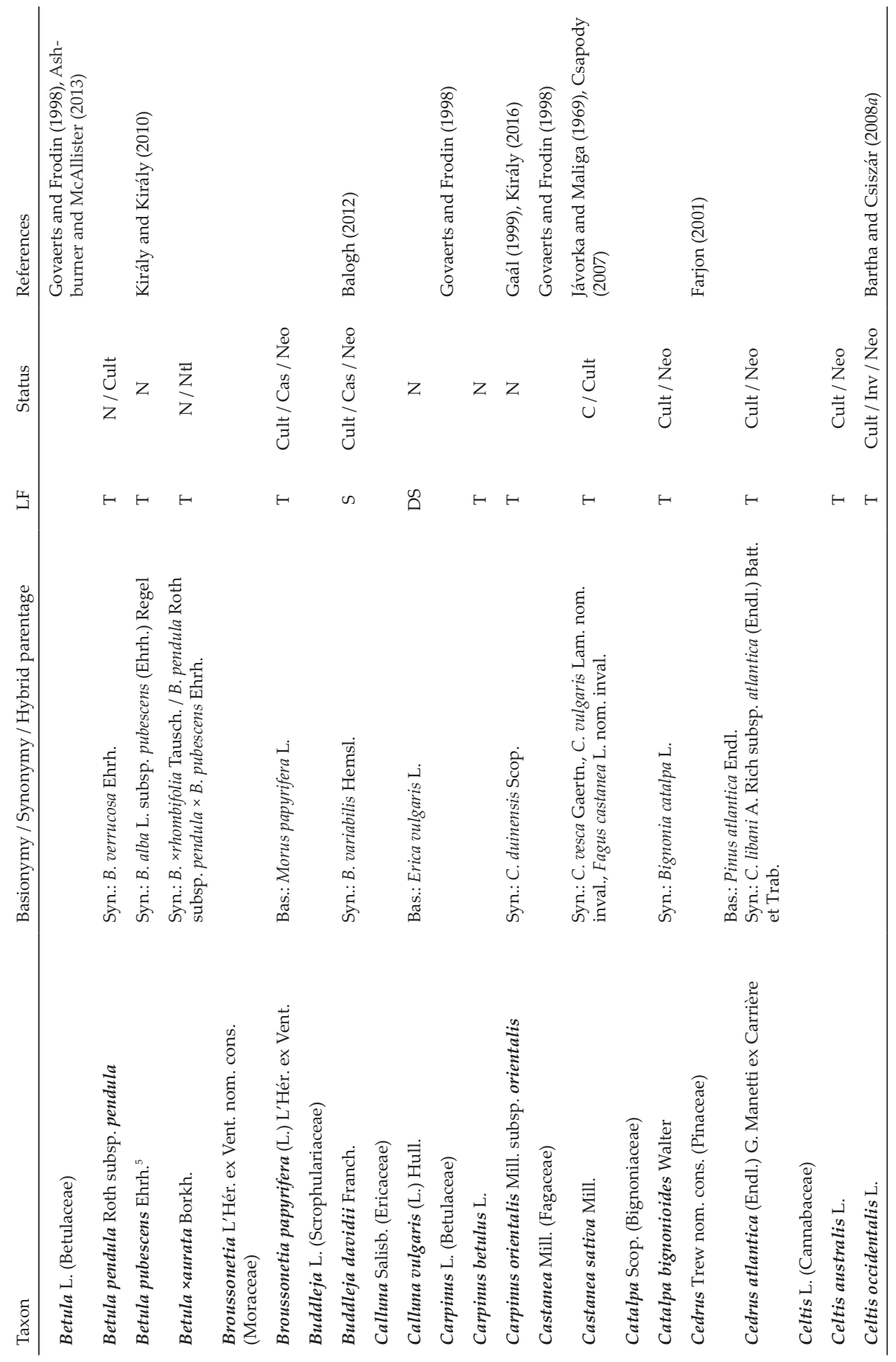




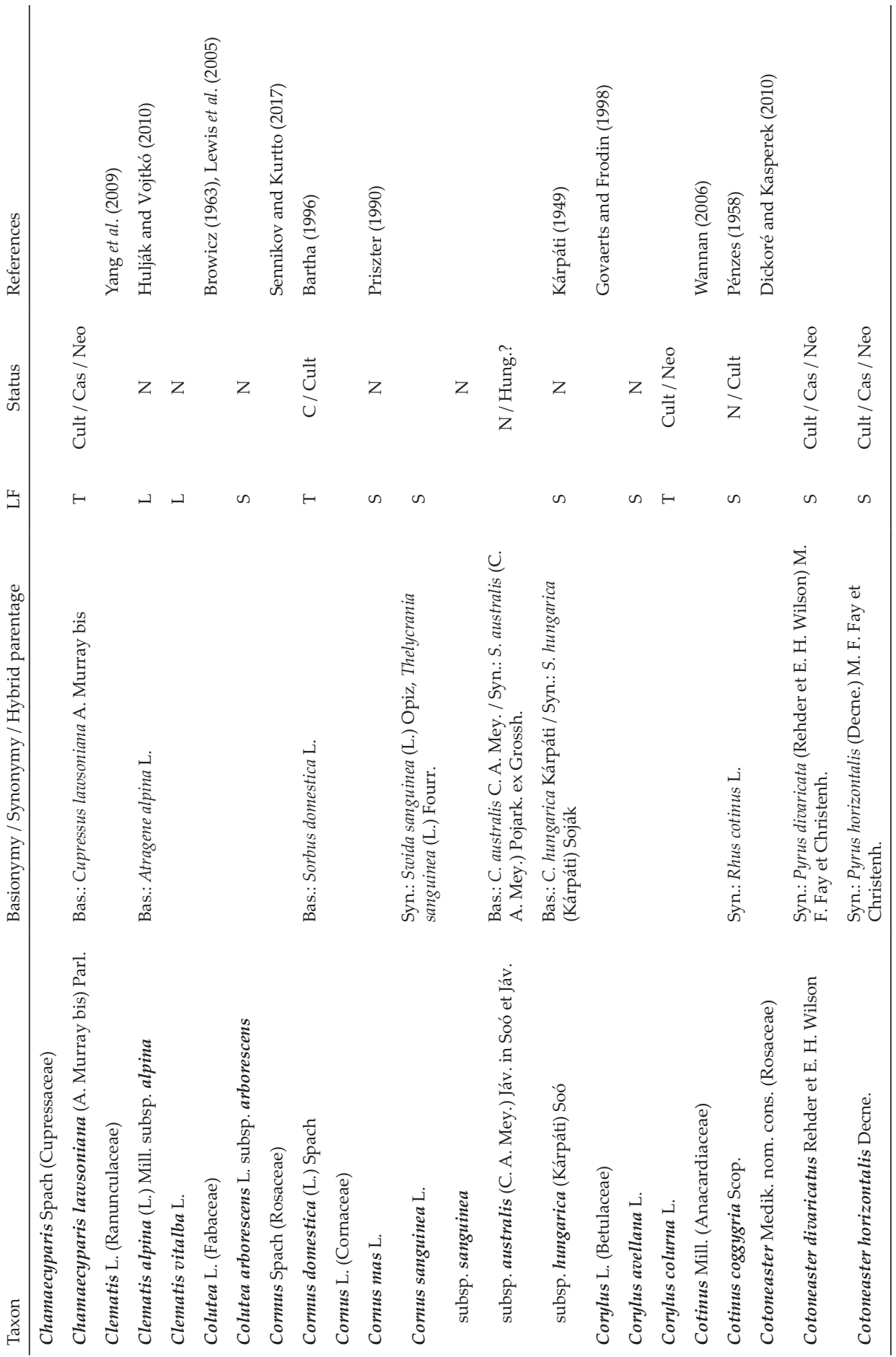




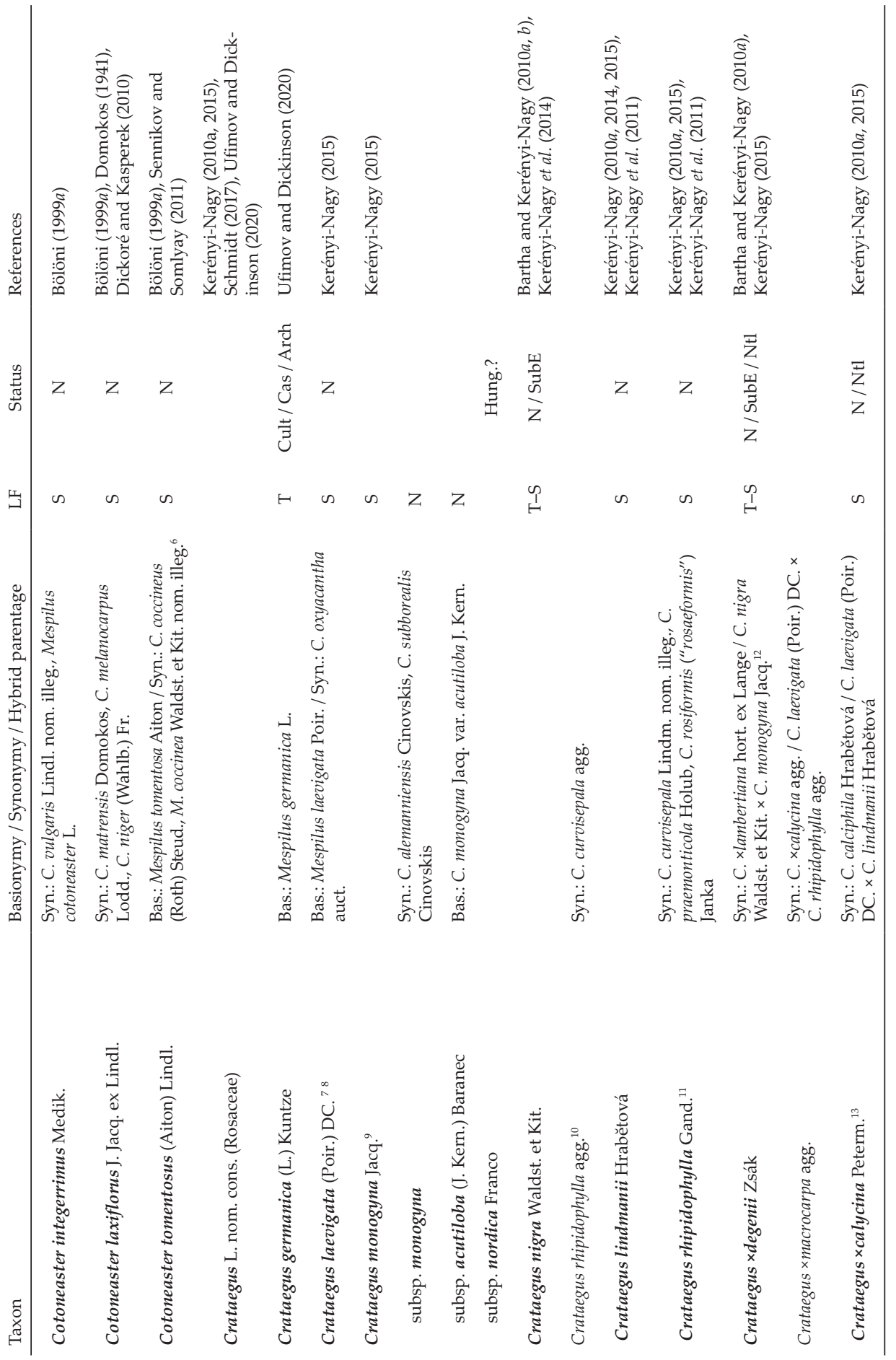




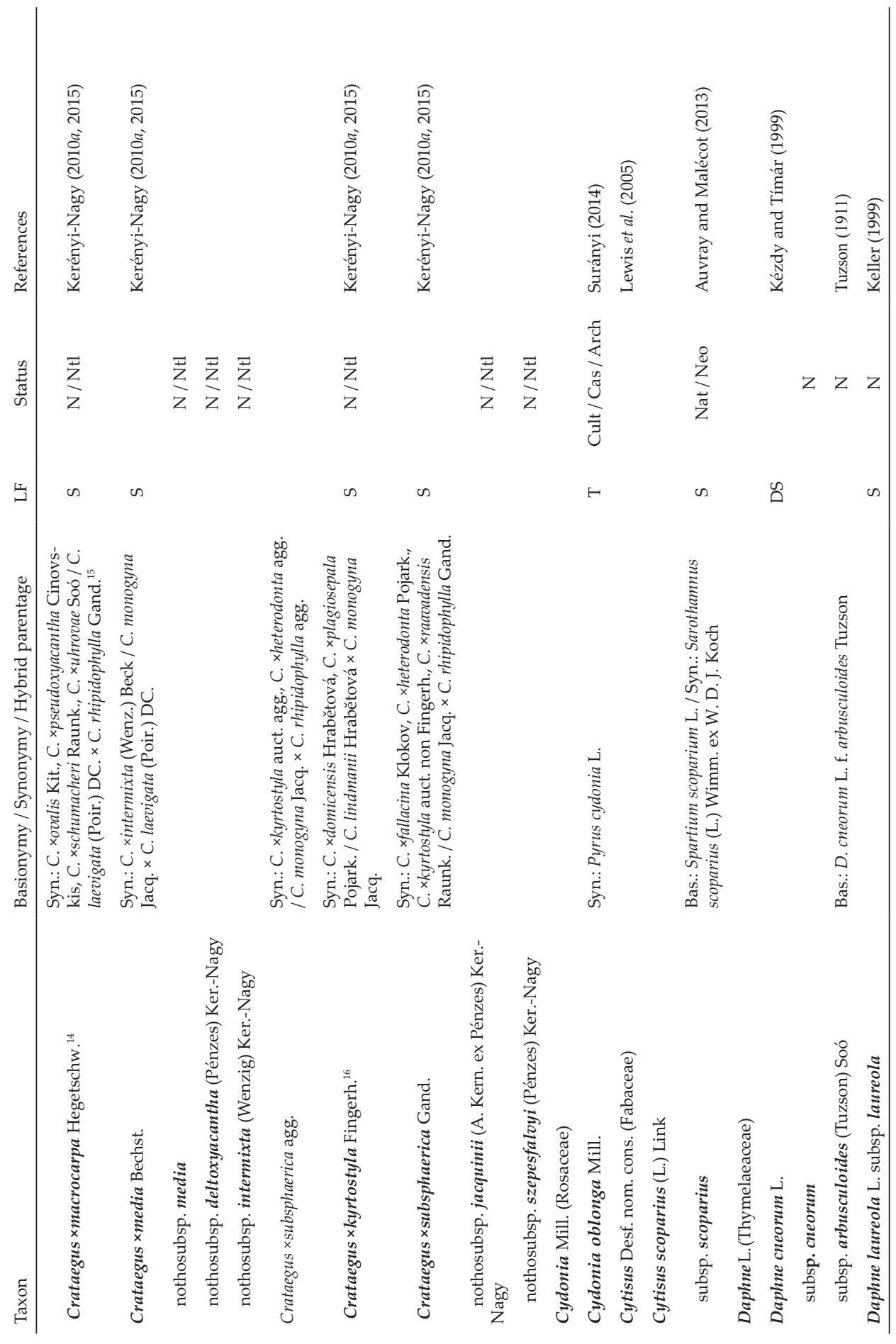




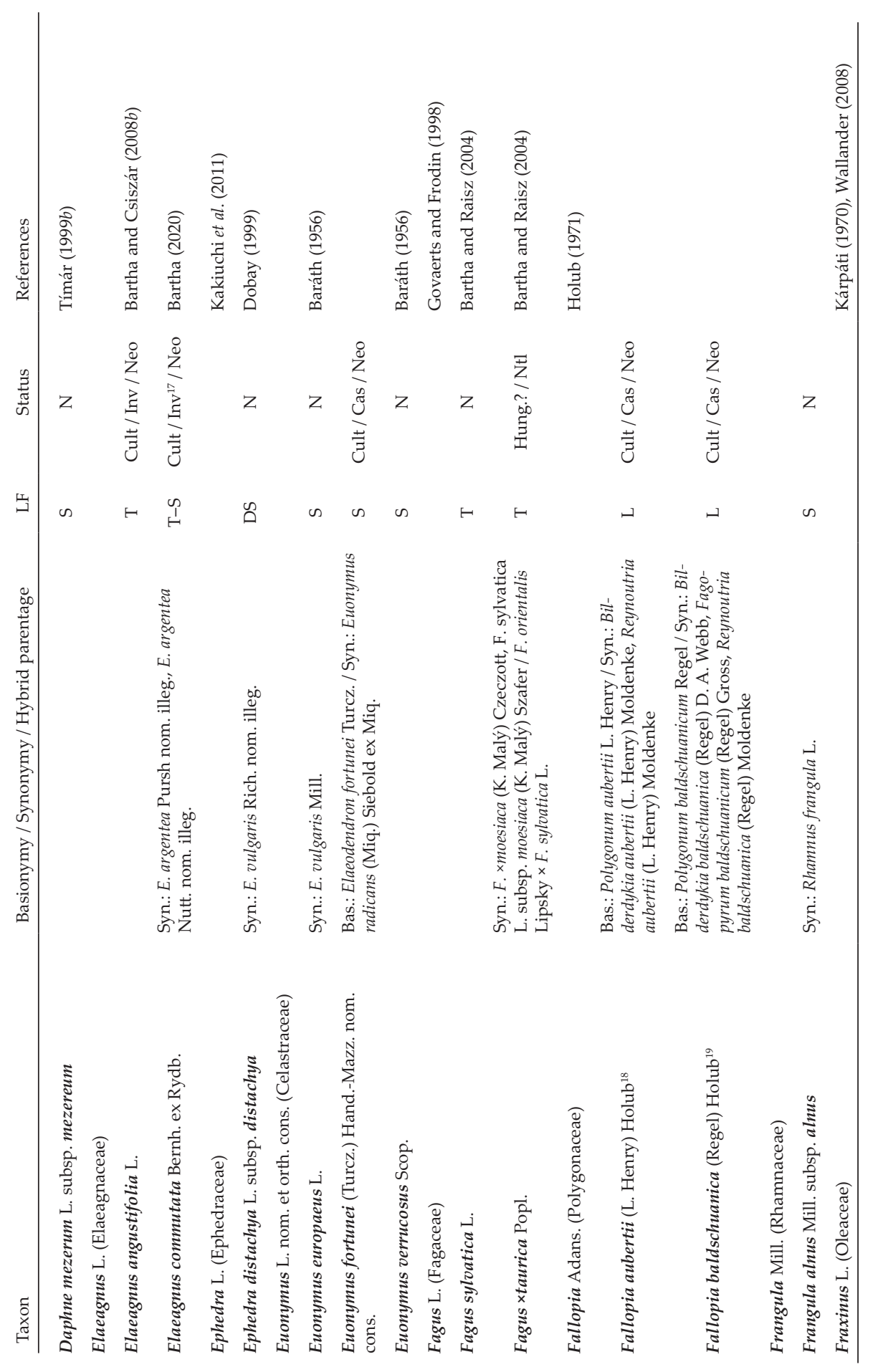




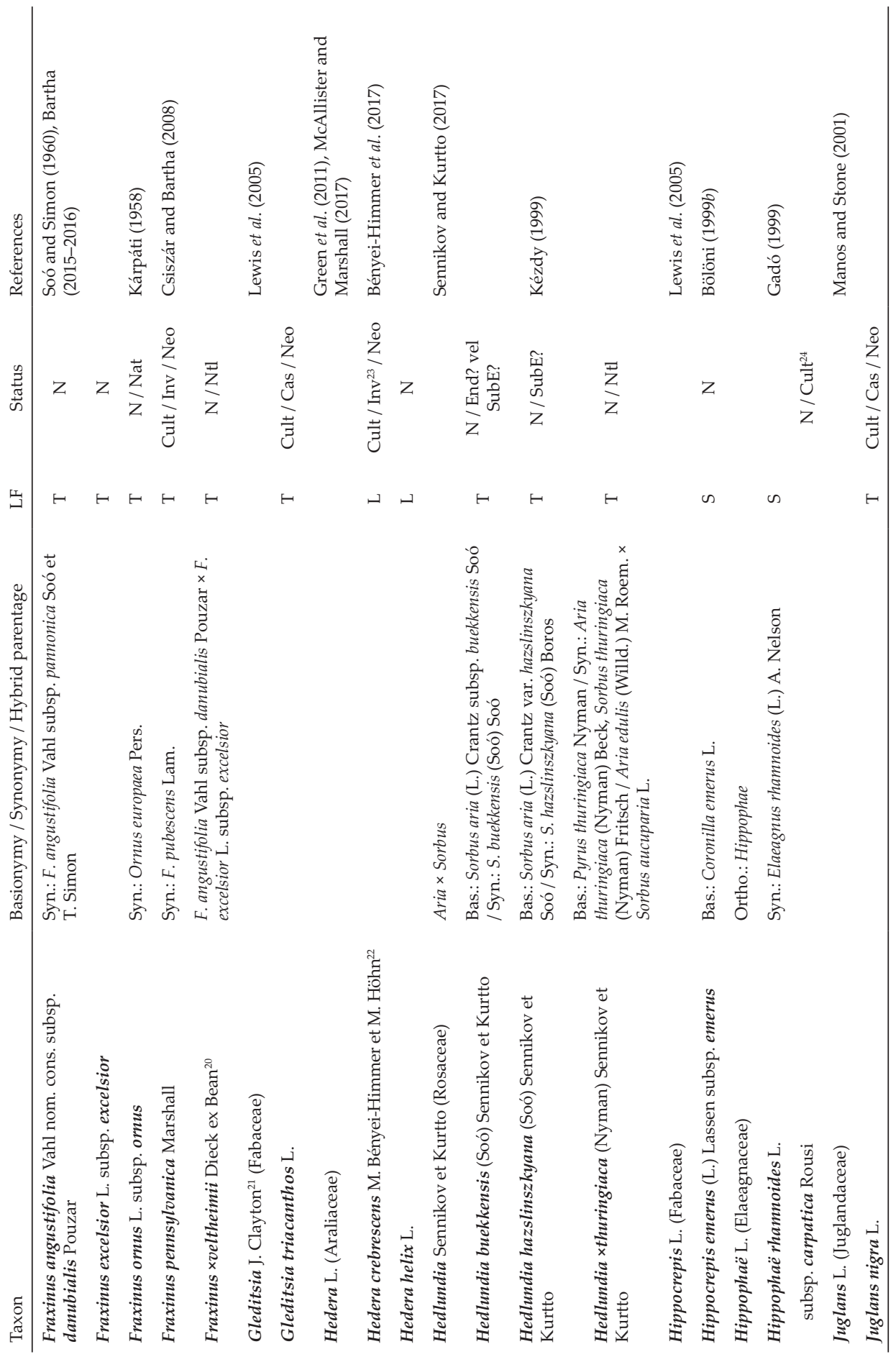




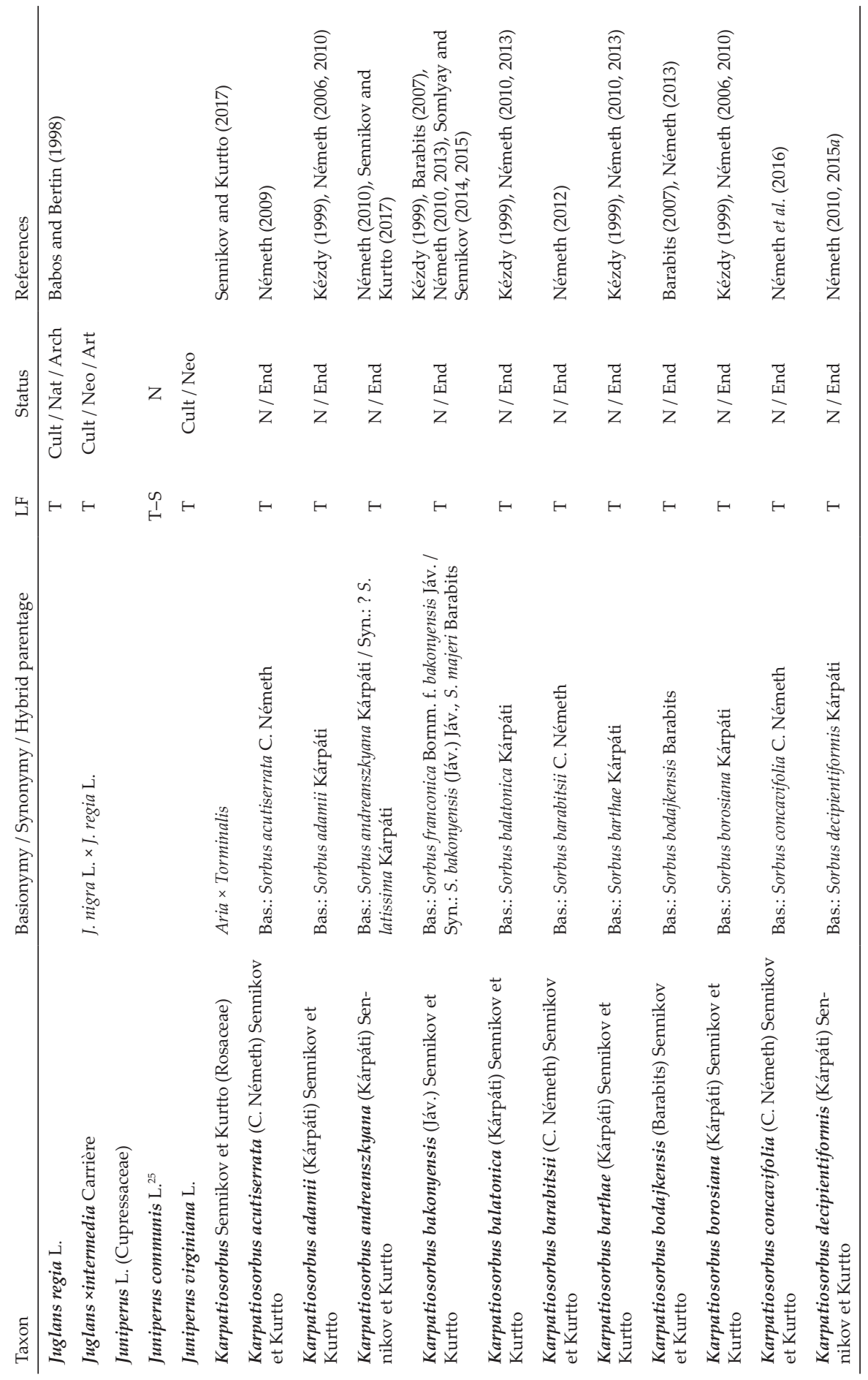




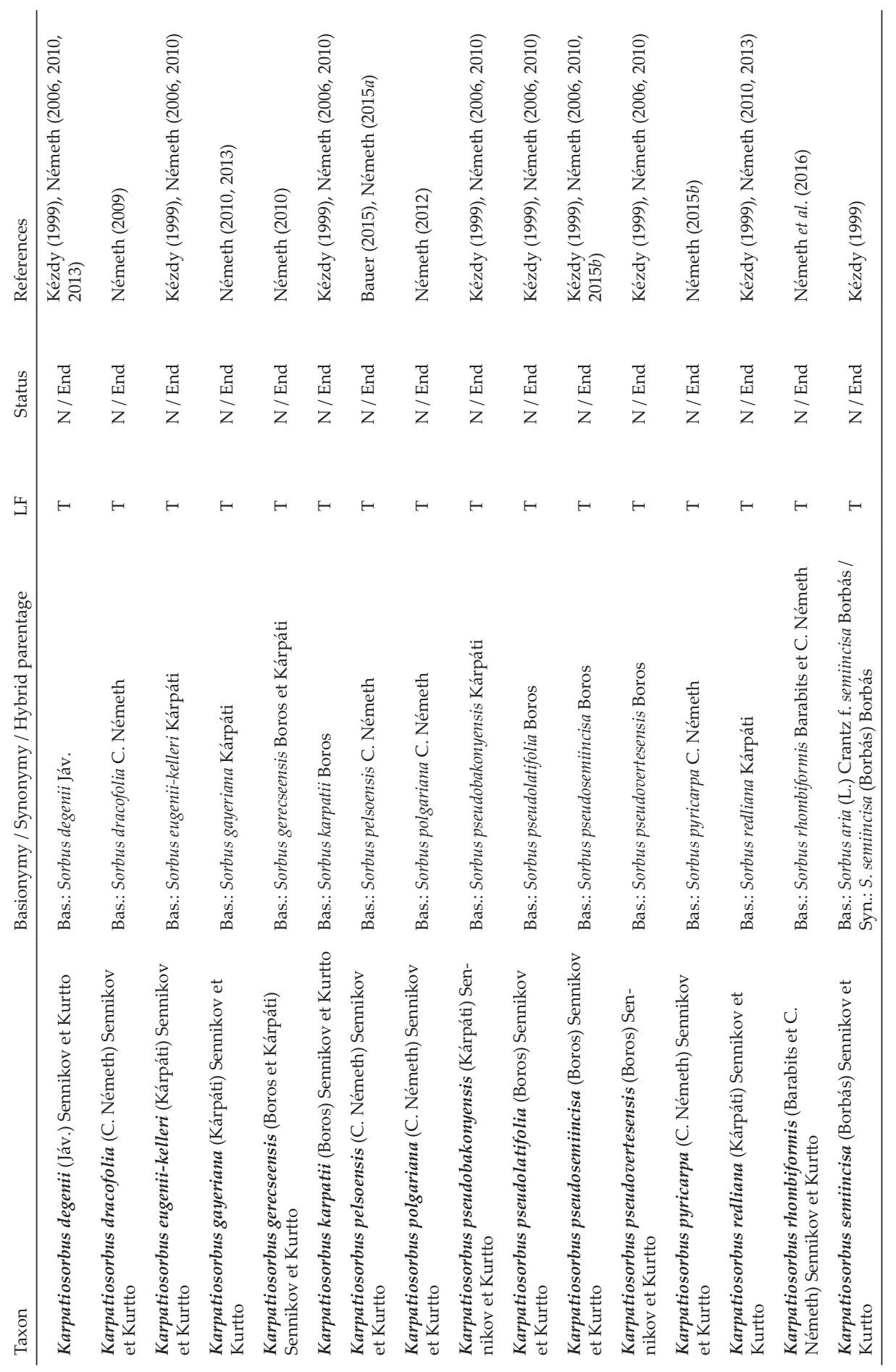




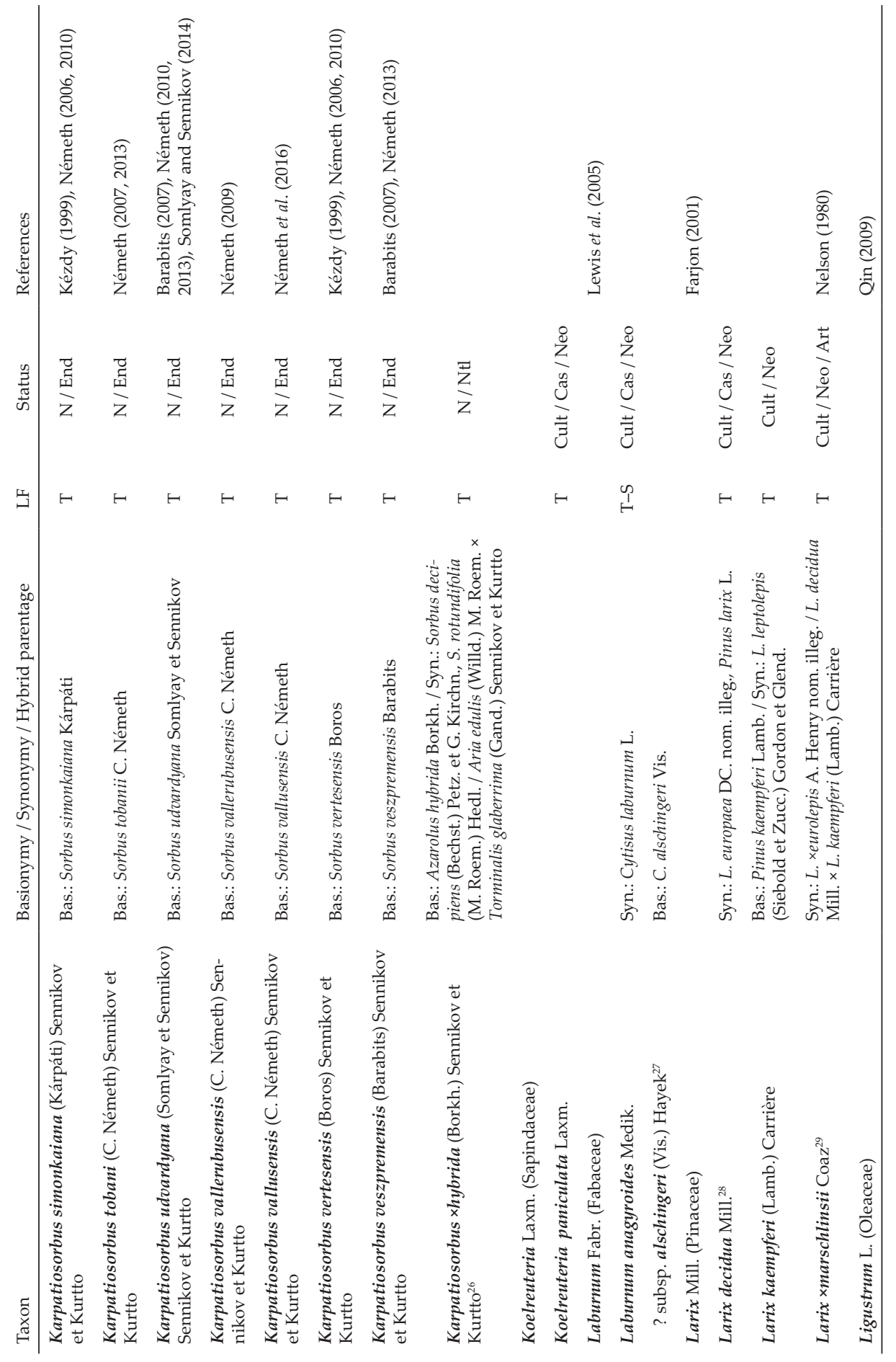




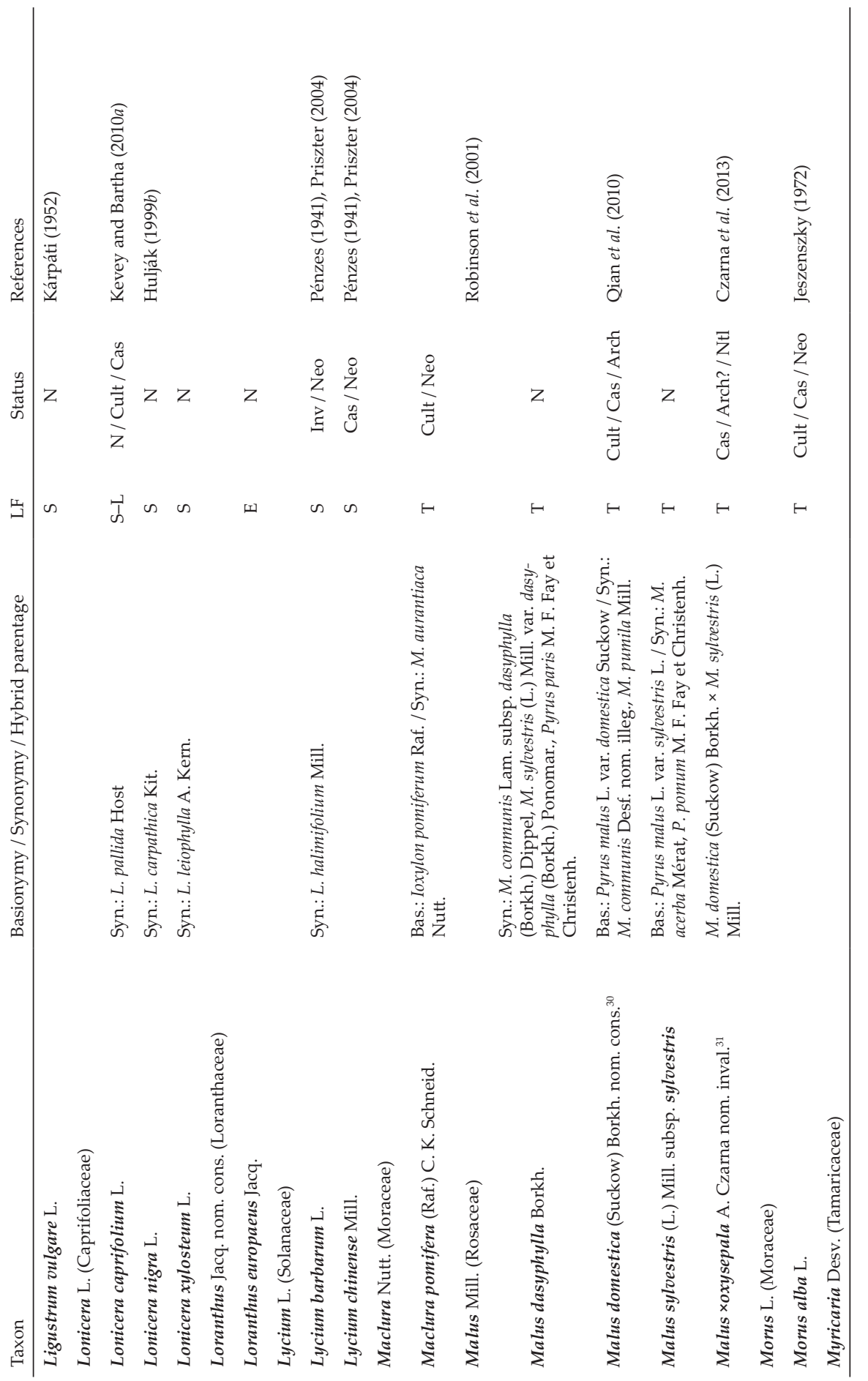




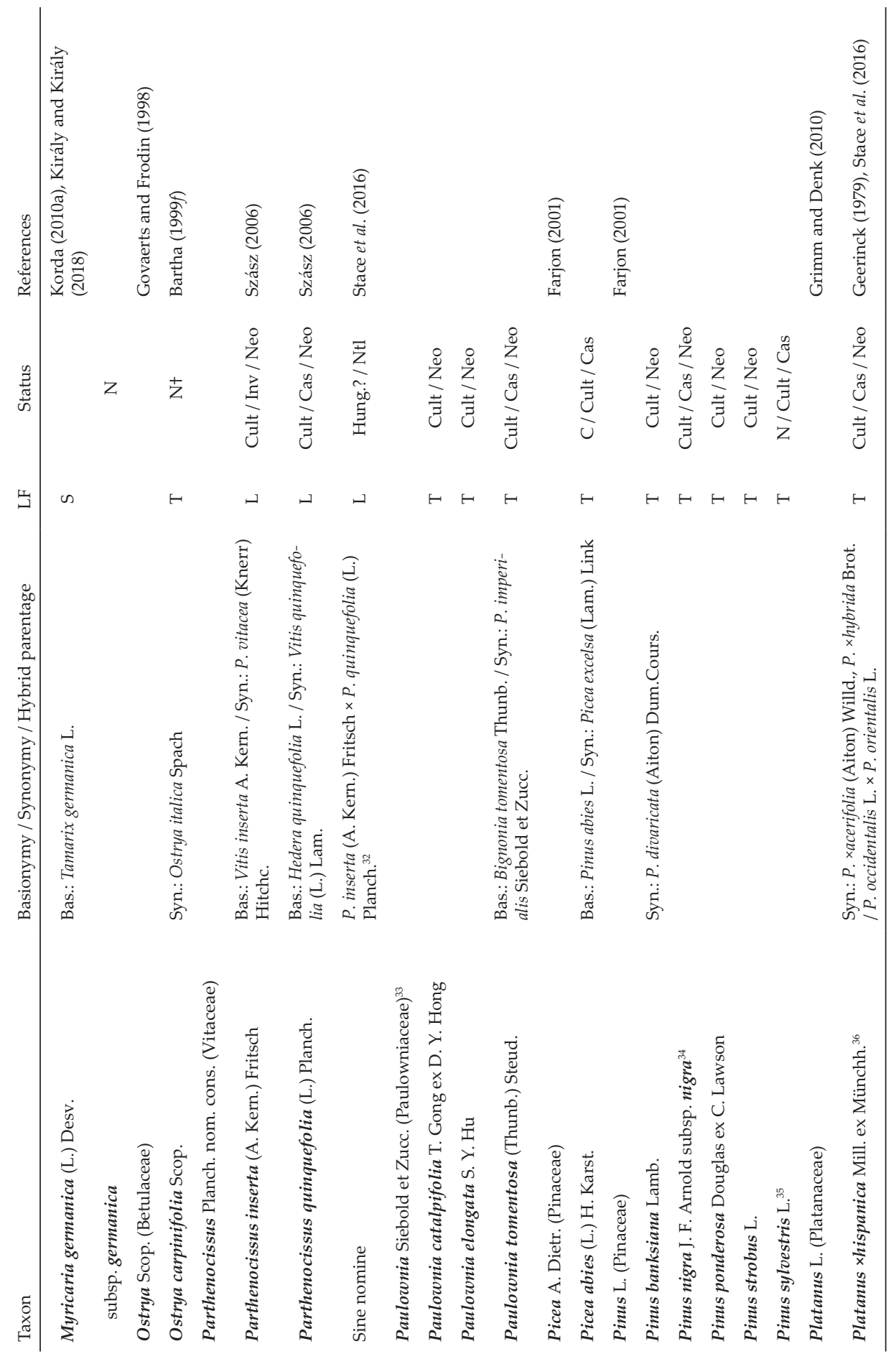




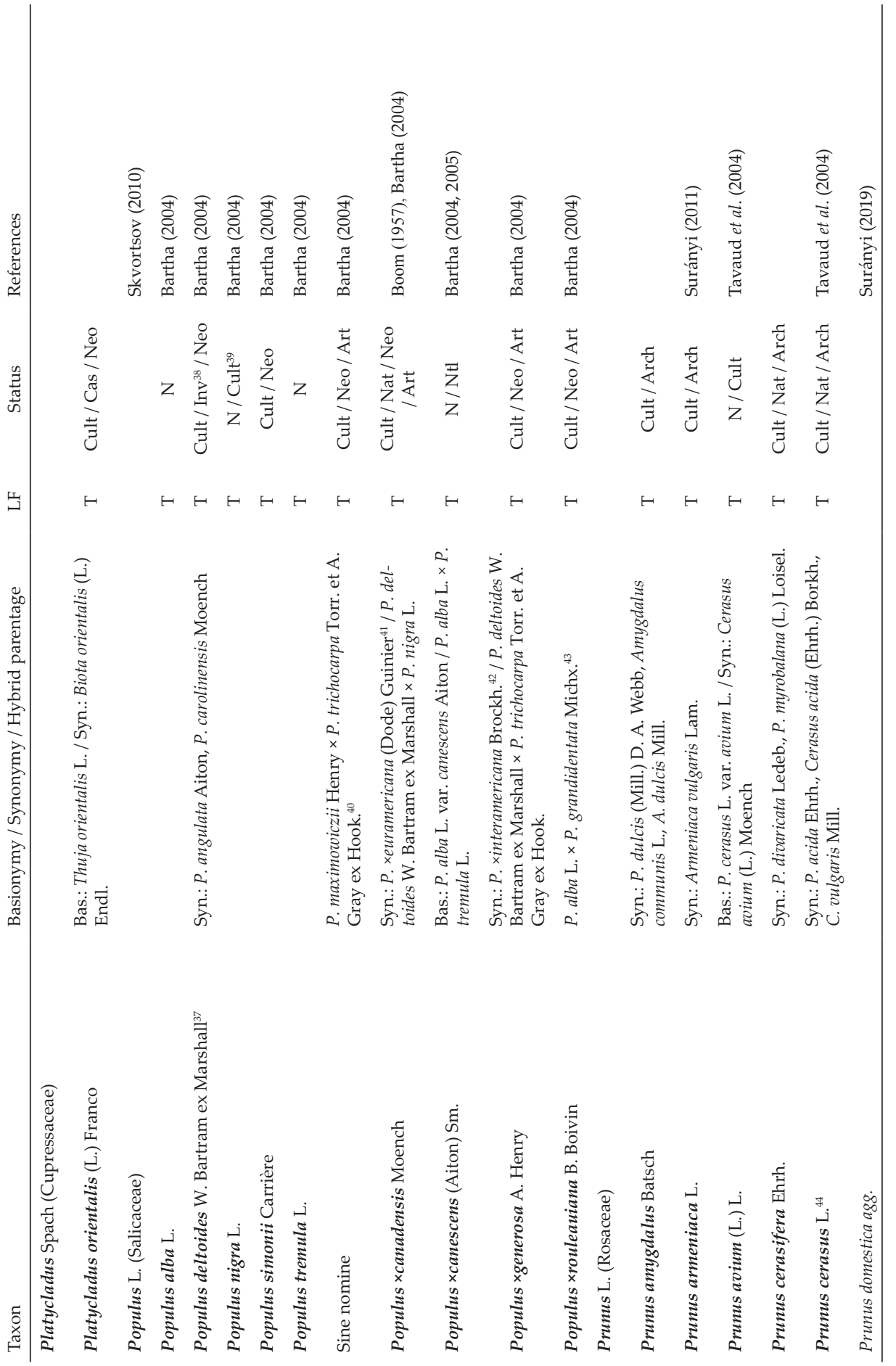




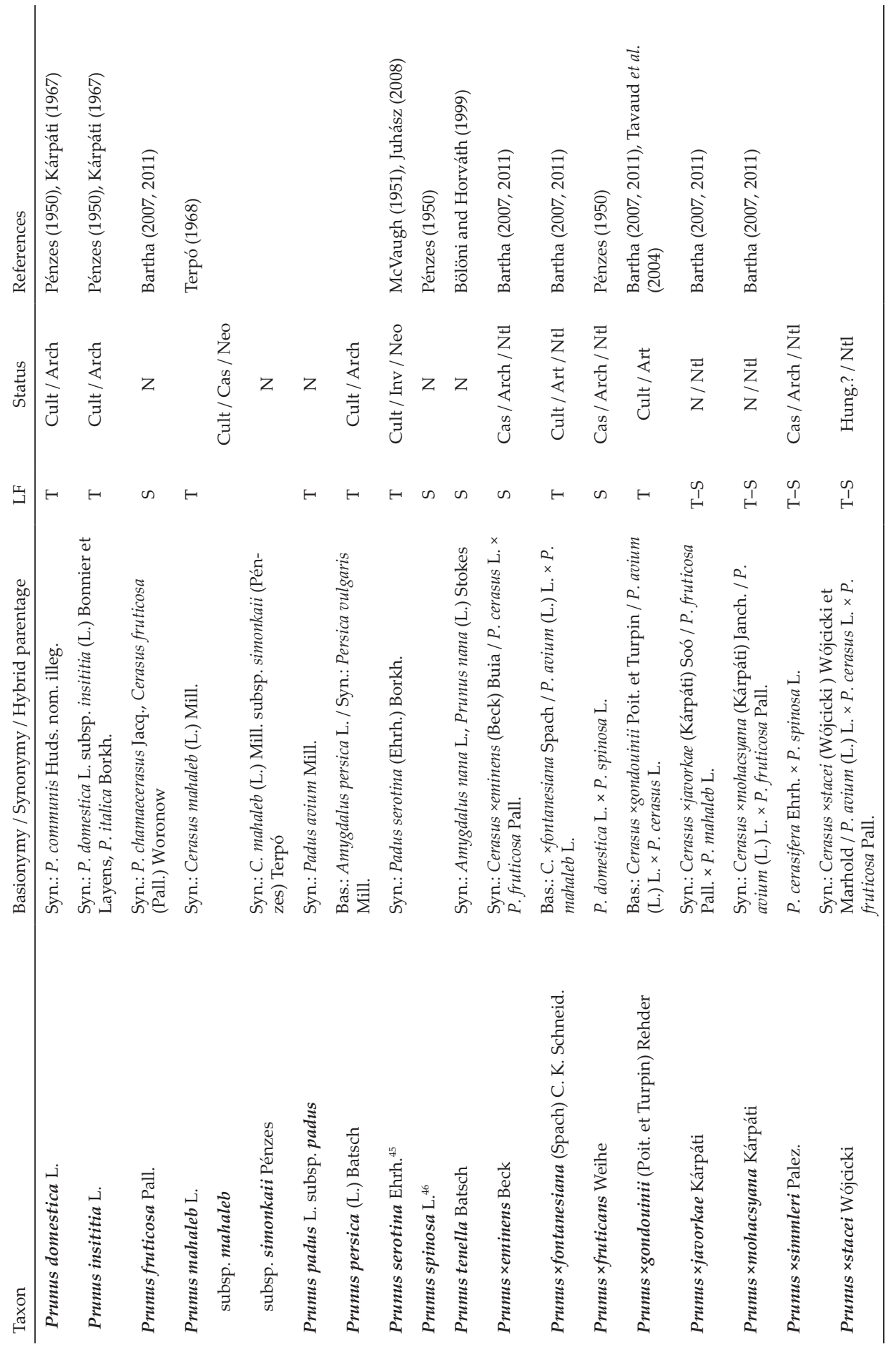




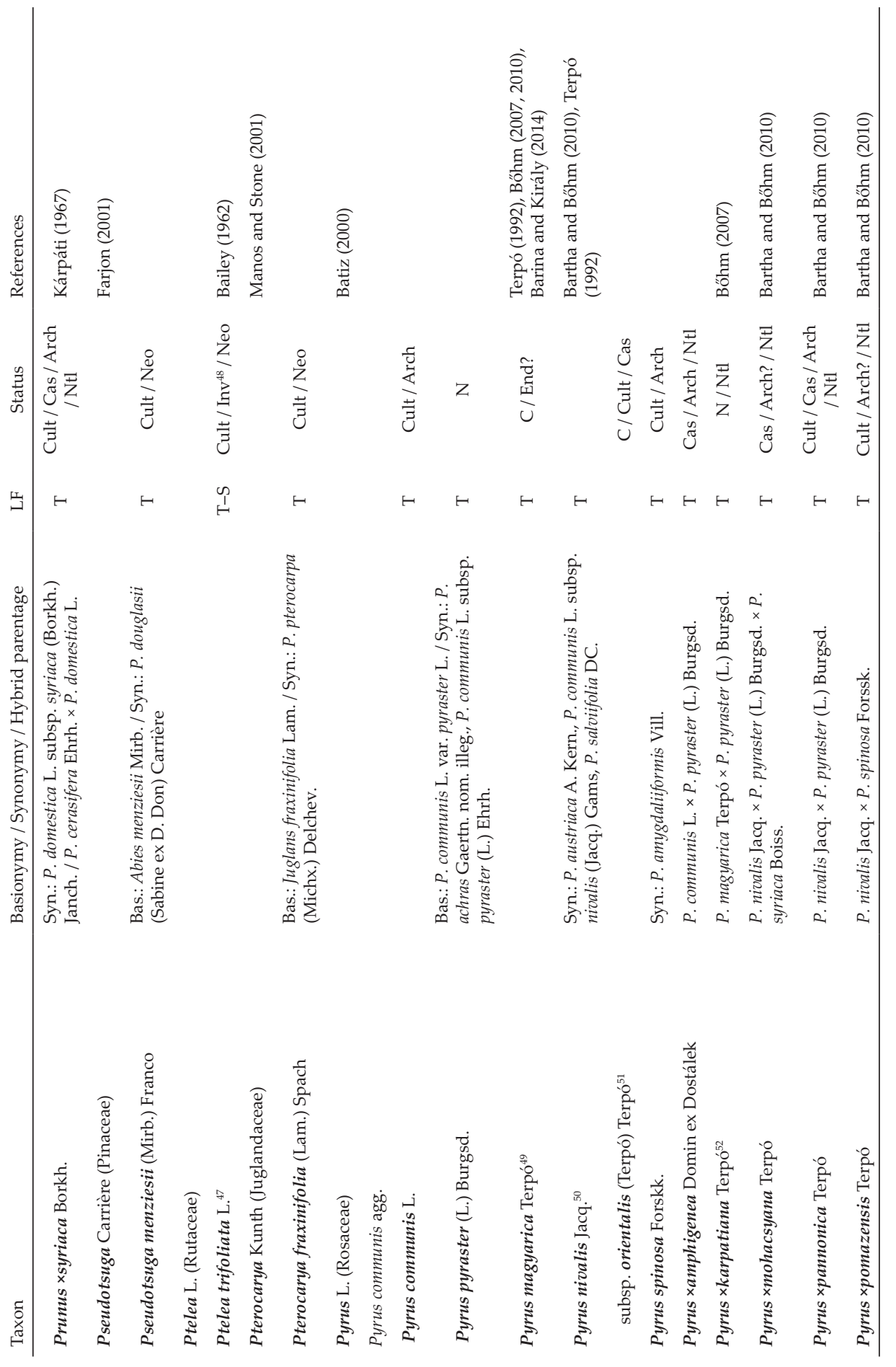




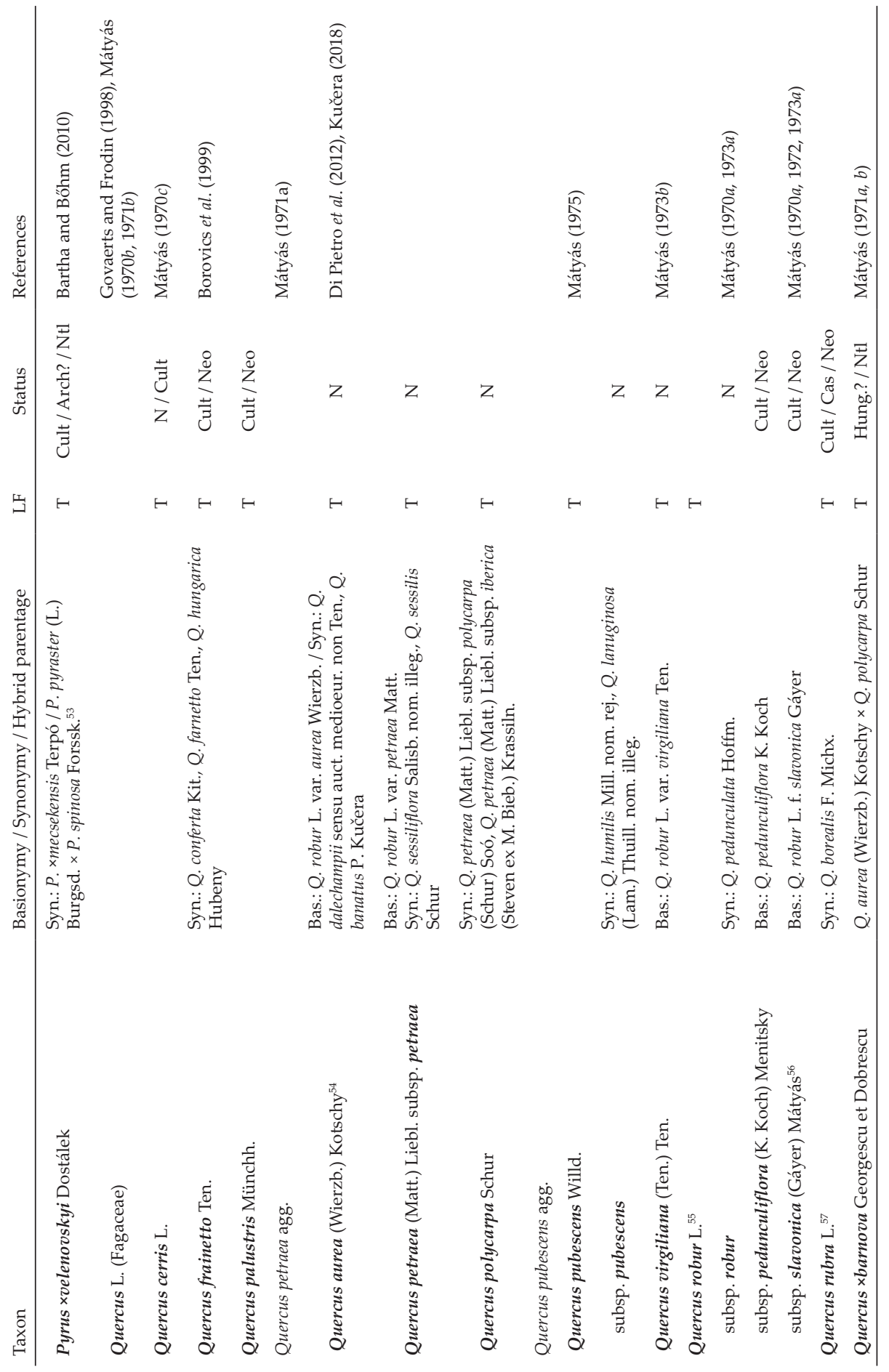




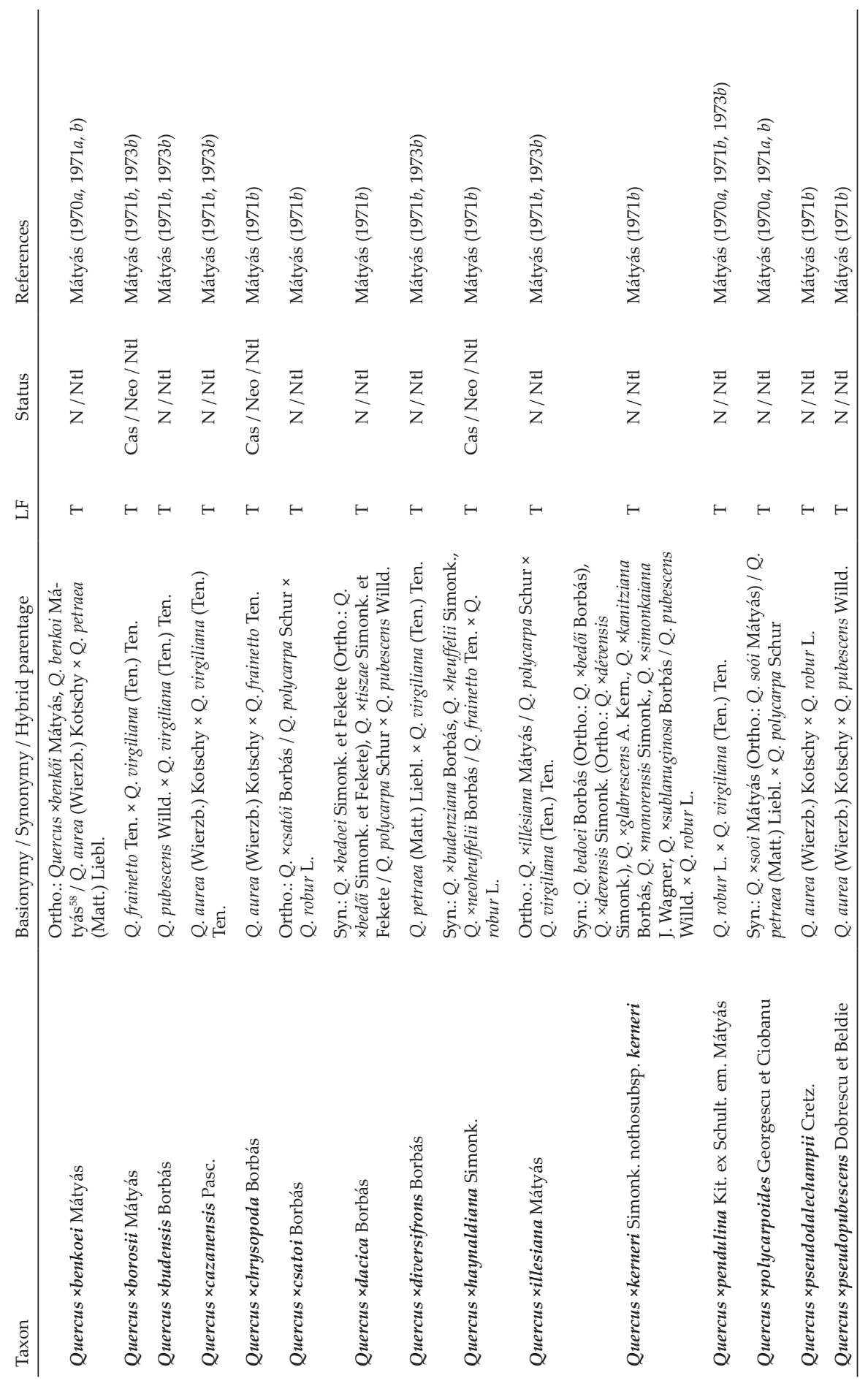




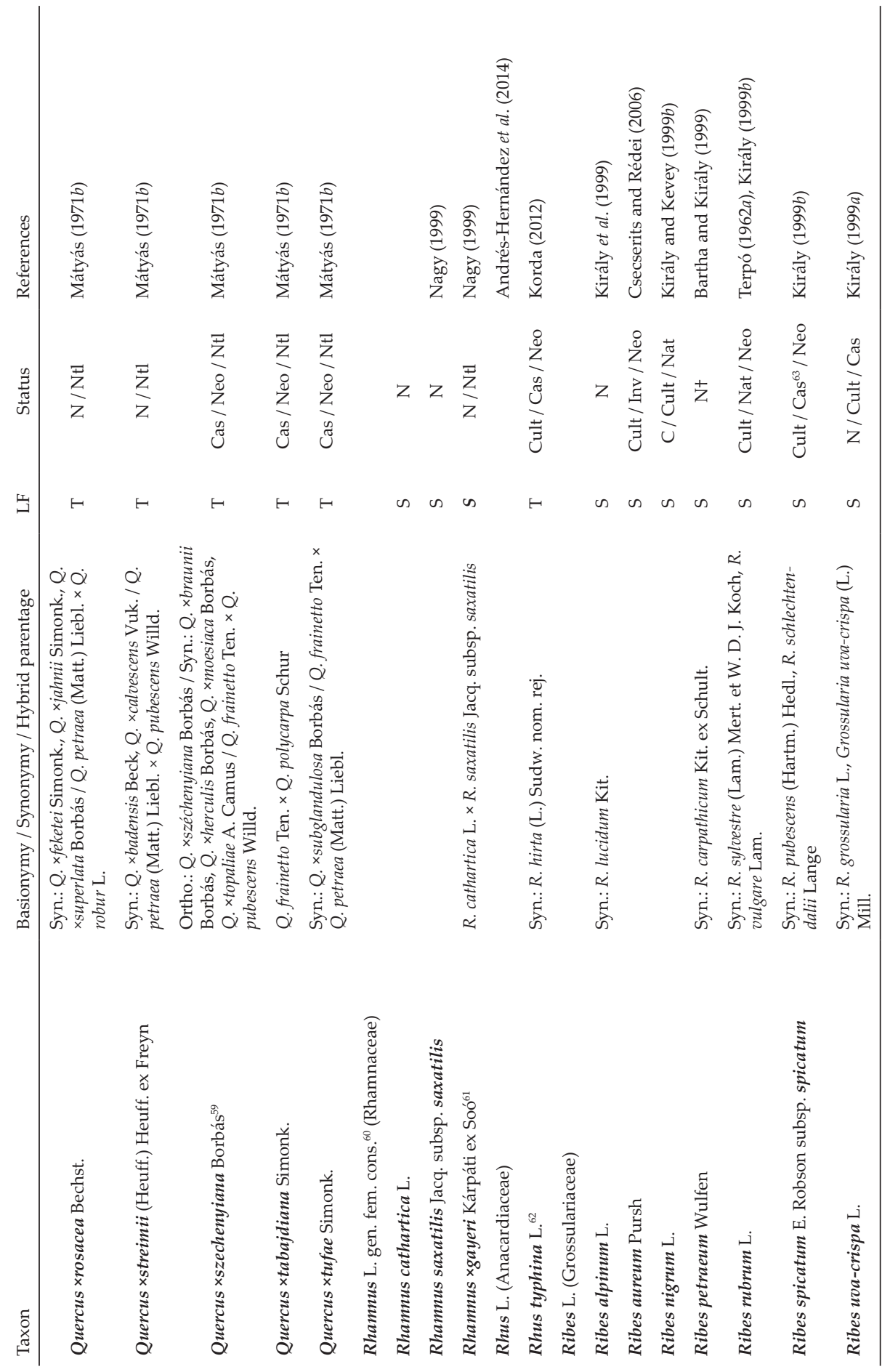




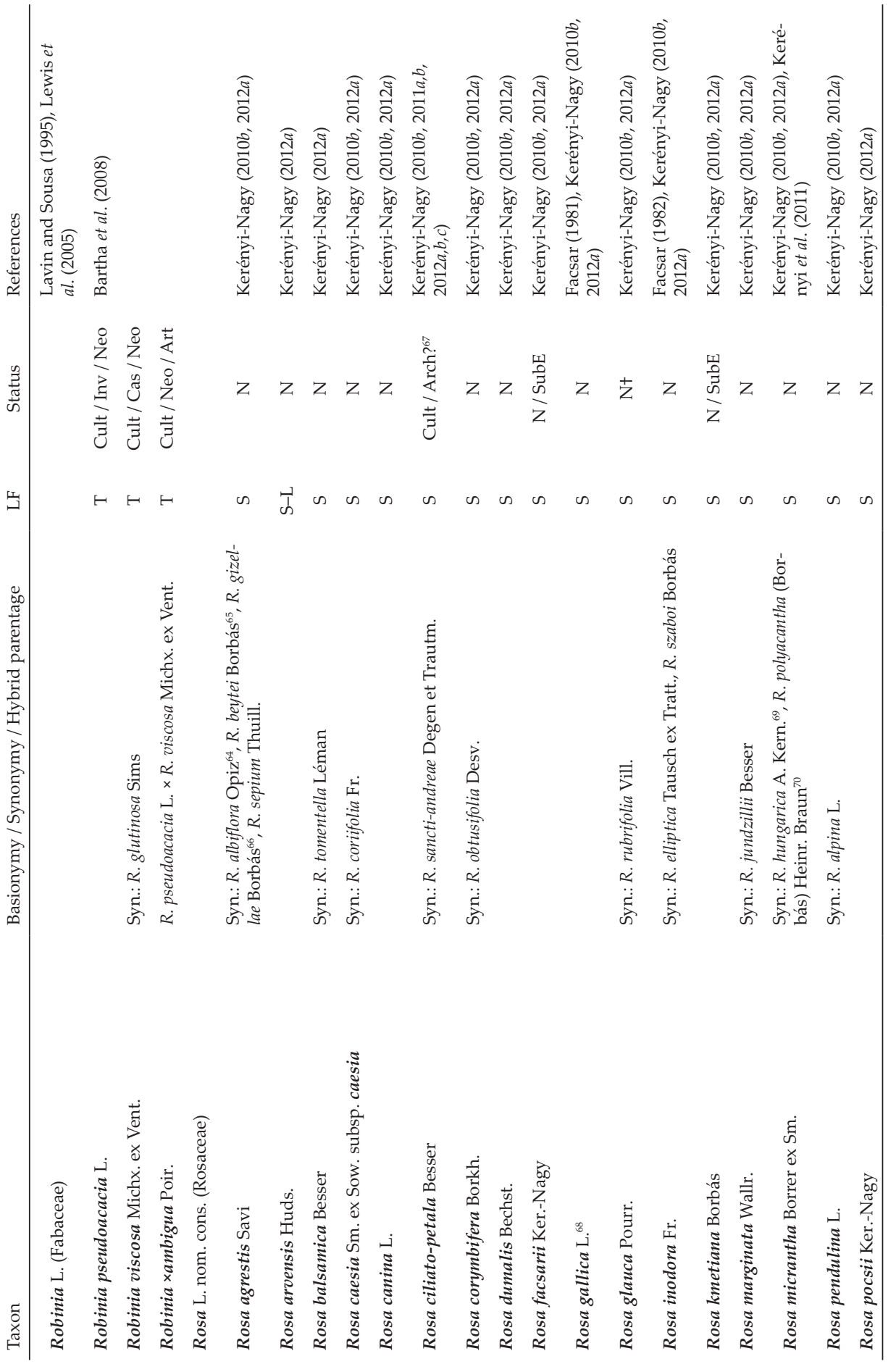




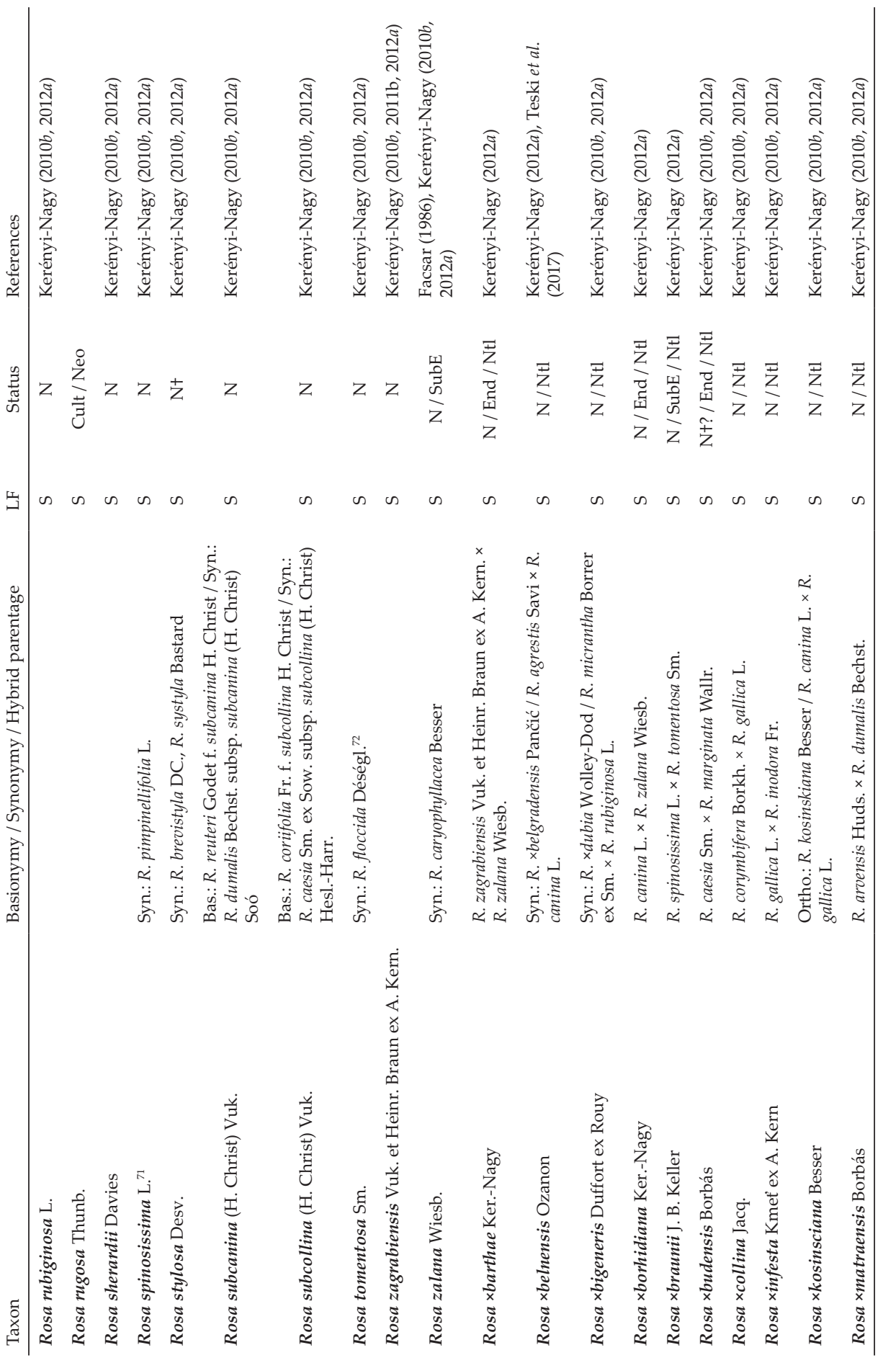




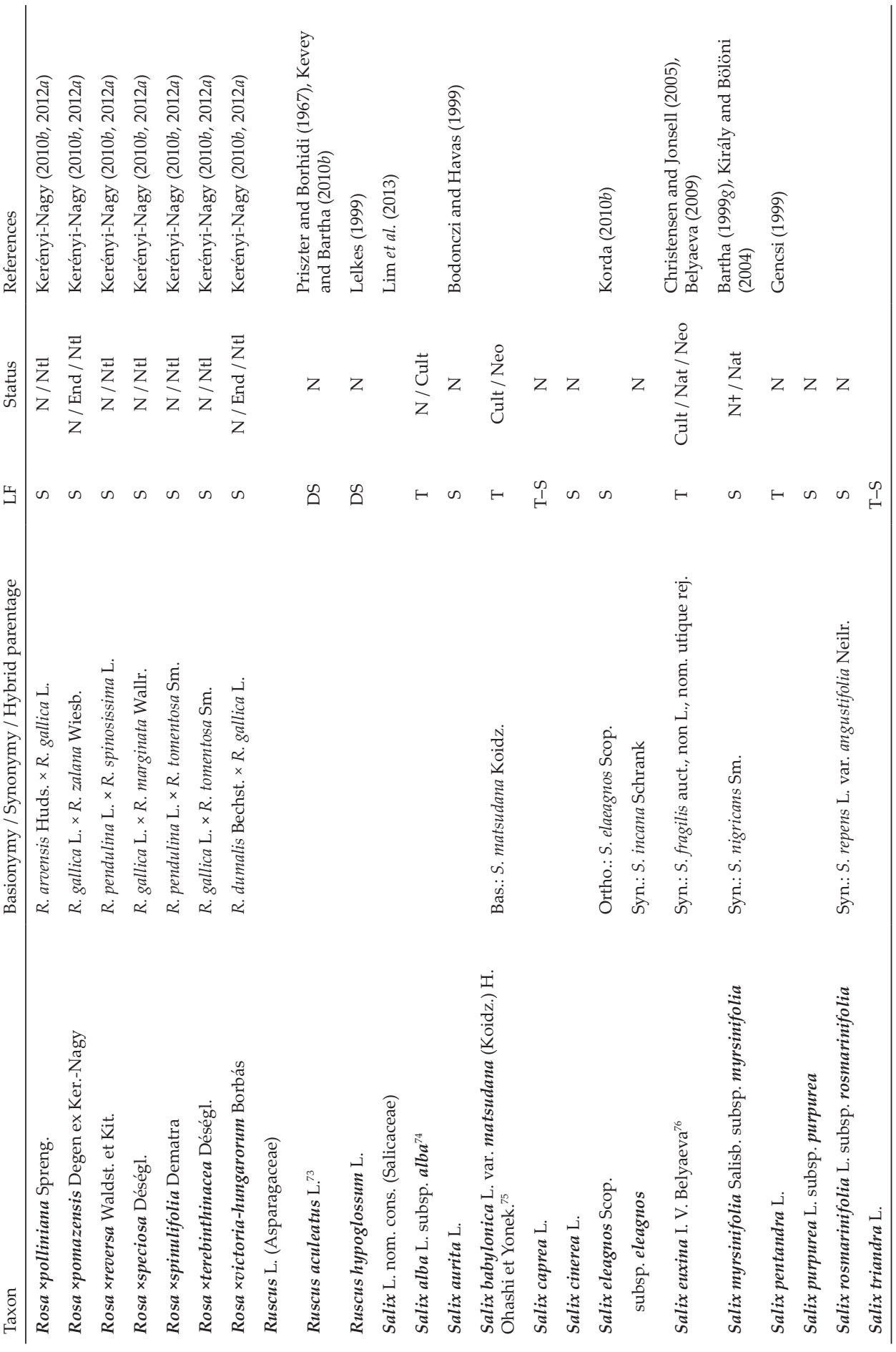




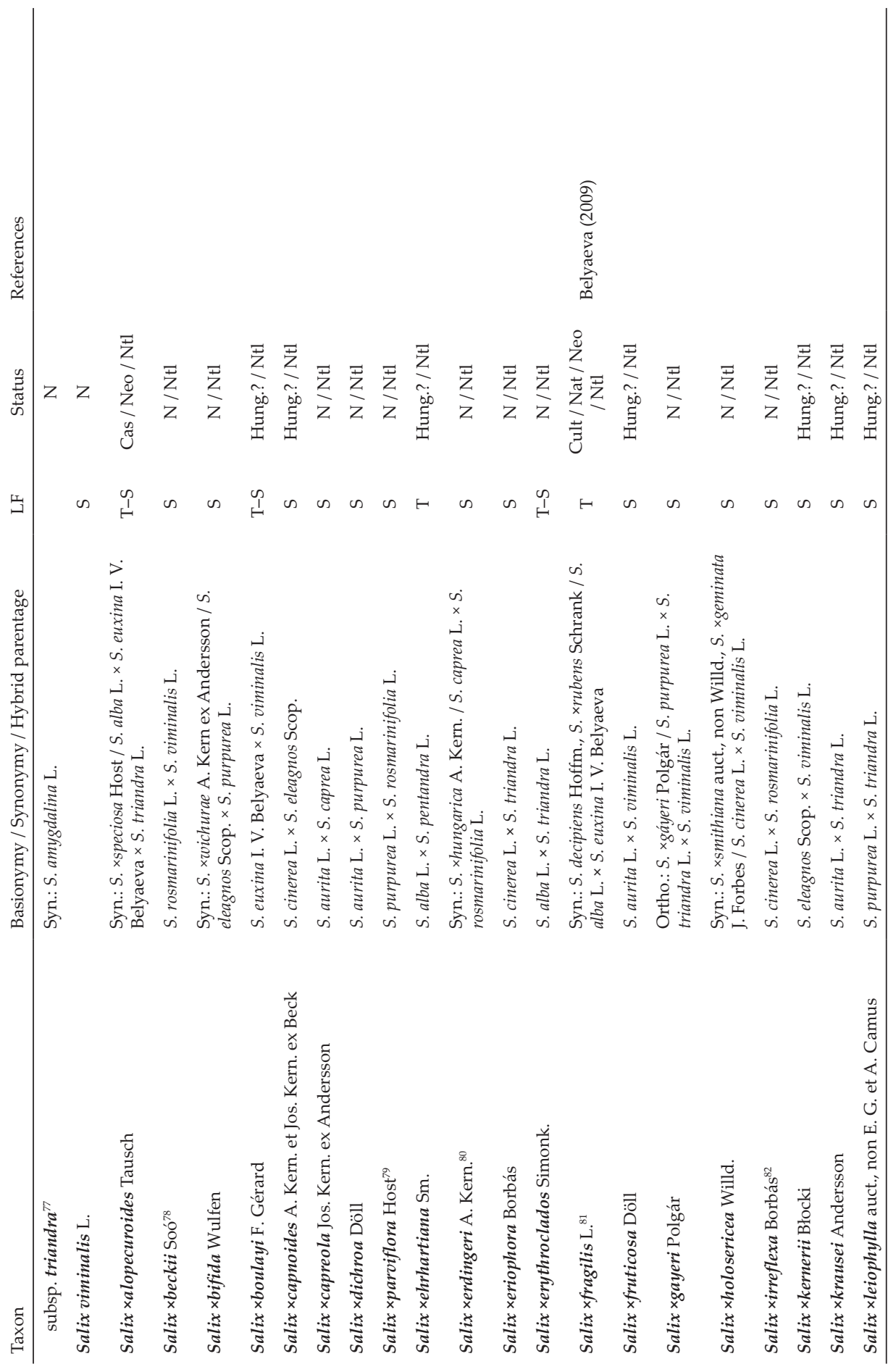




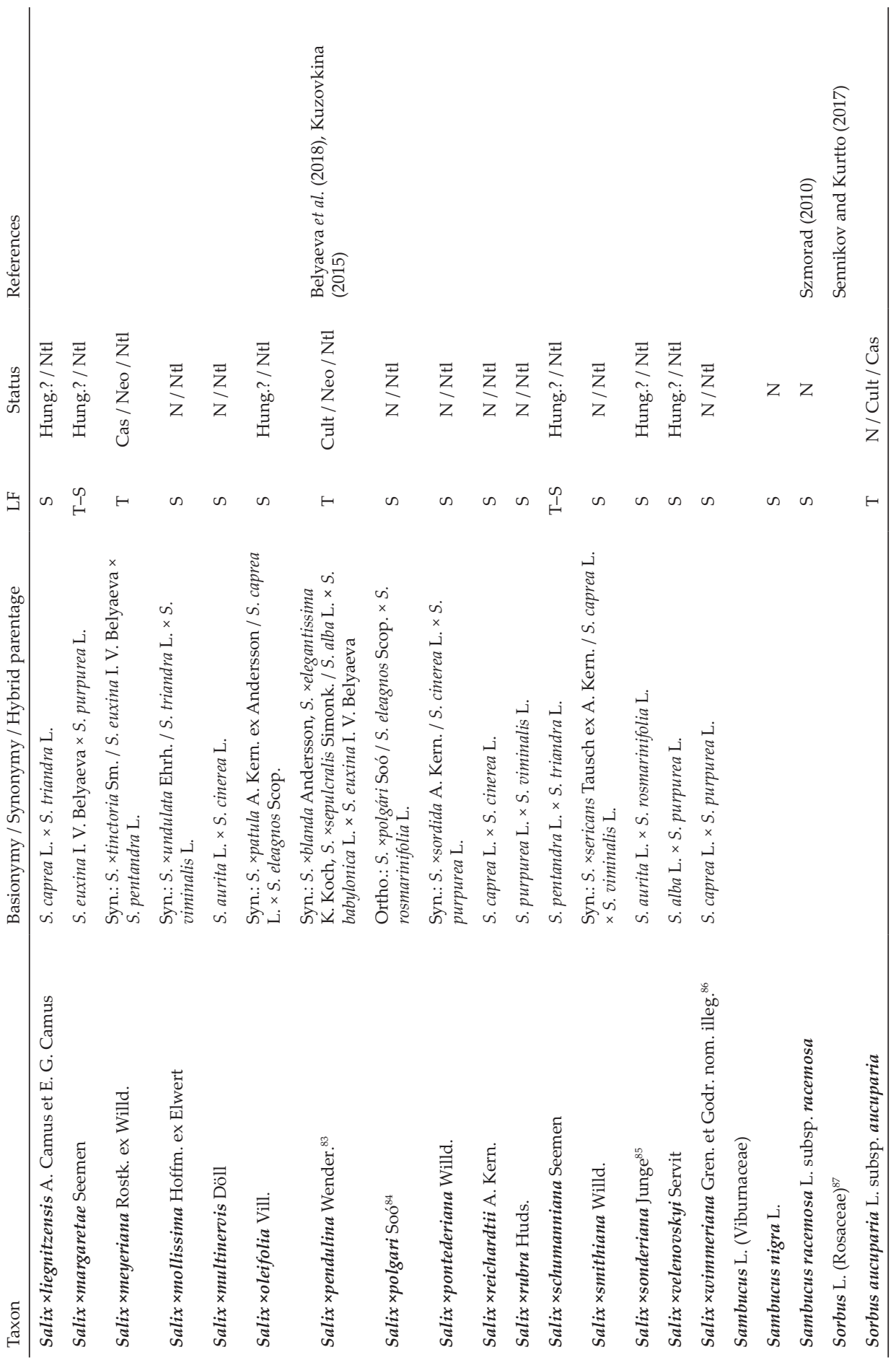




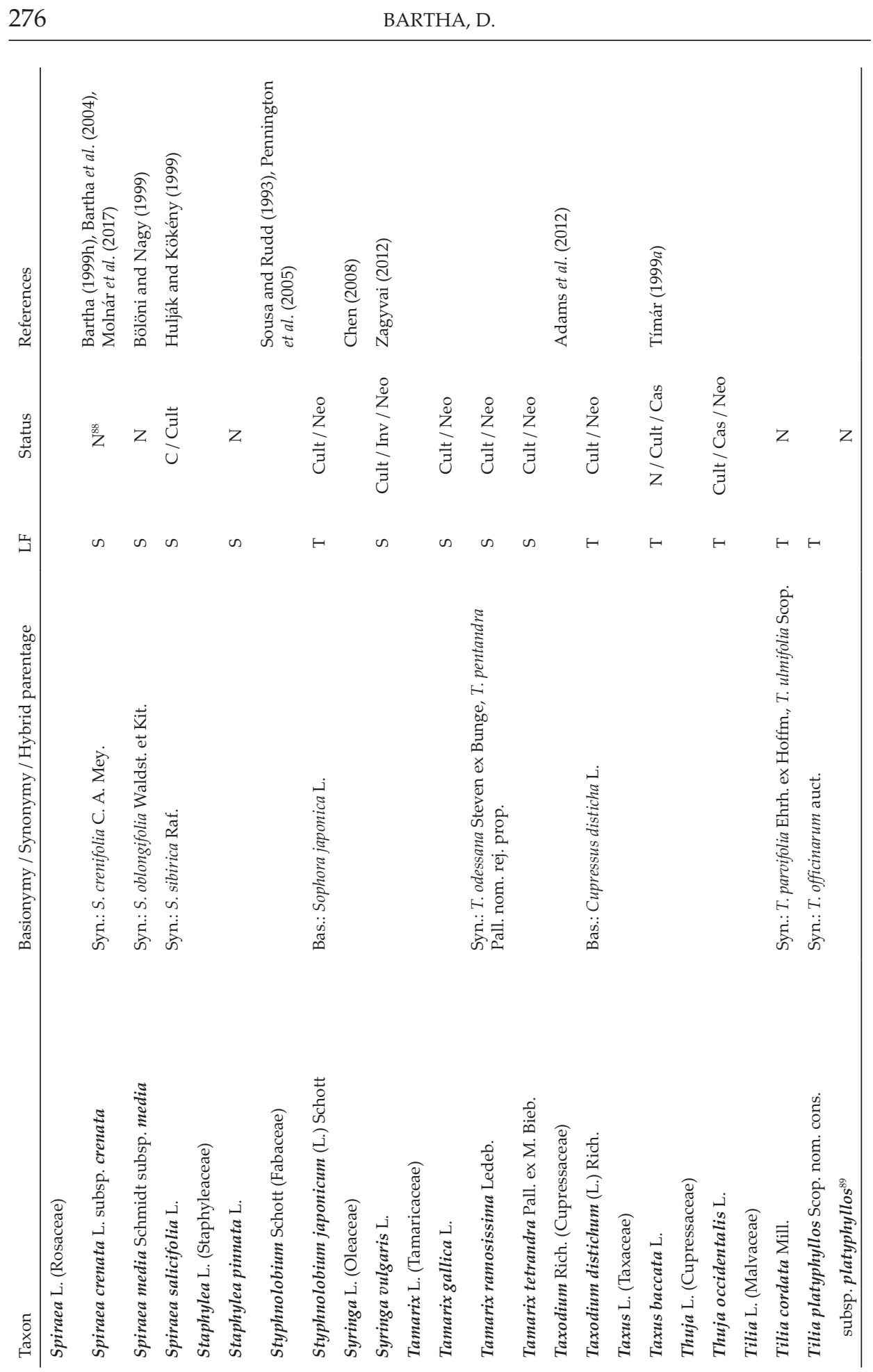

Act Bot. Hung. 63, 2021

Unauthenticated | Downloaded 04/26/23 03:12 PM UTC 


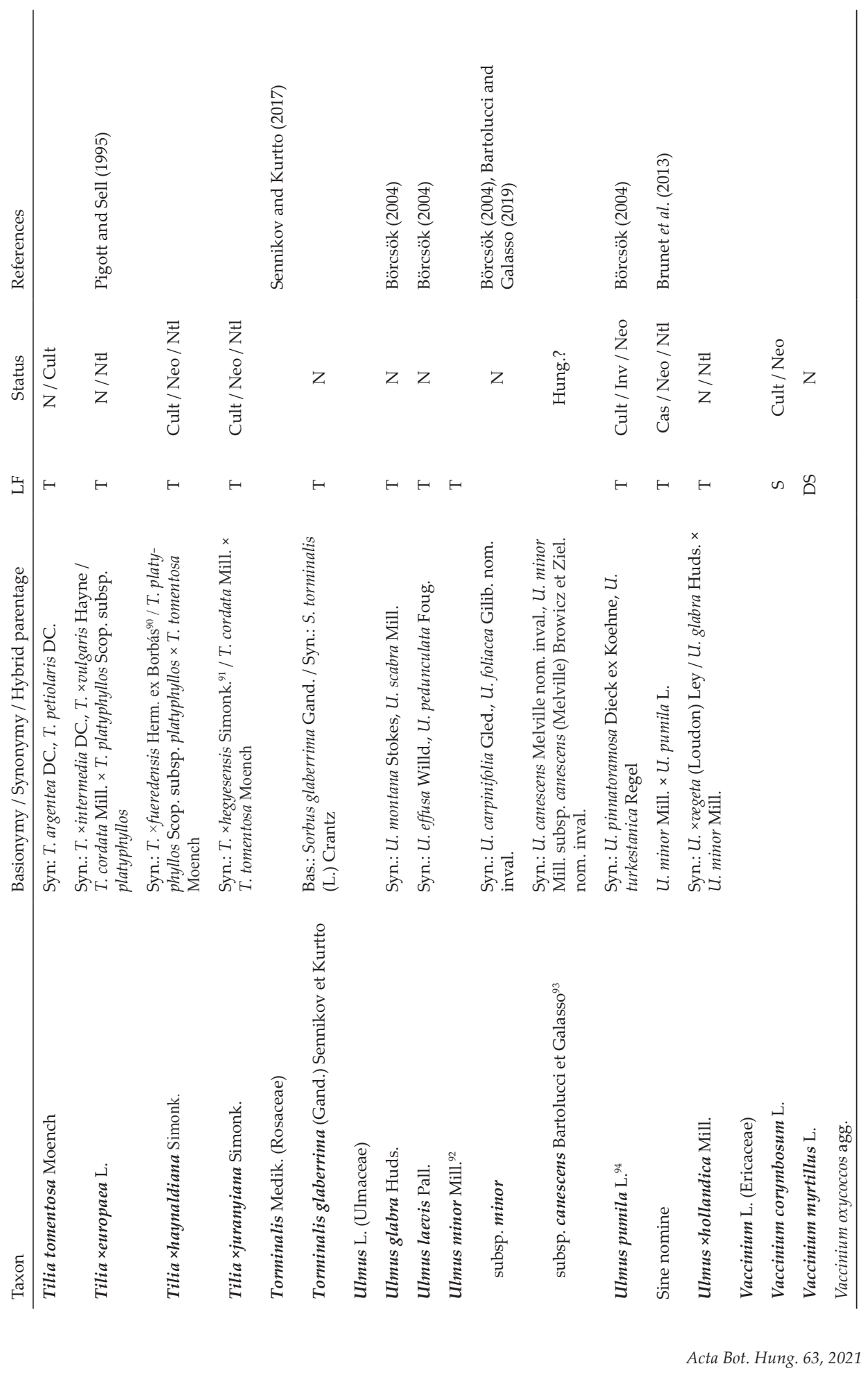




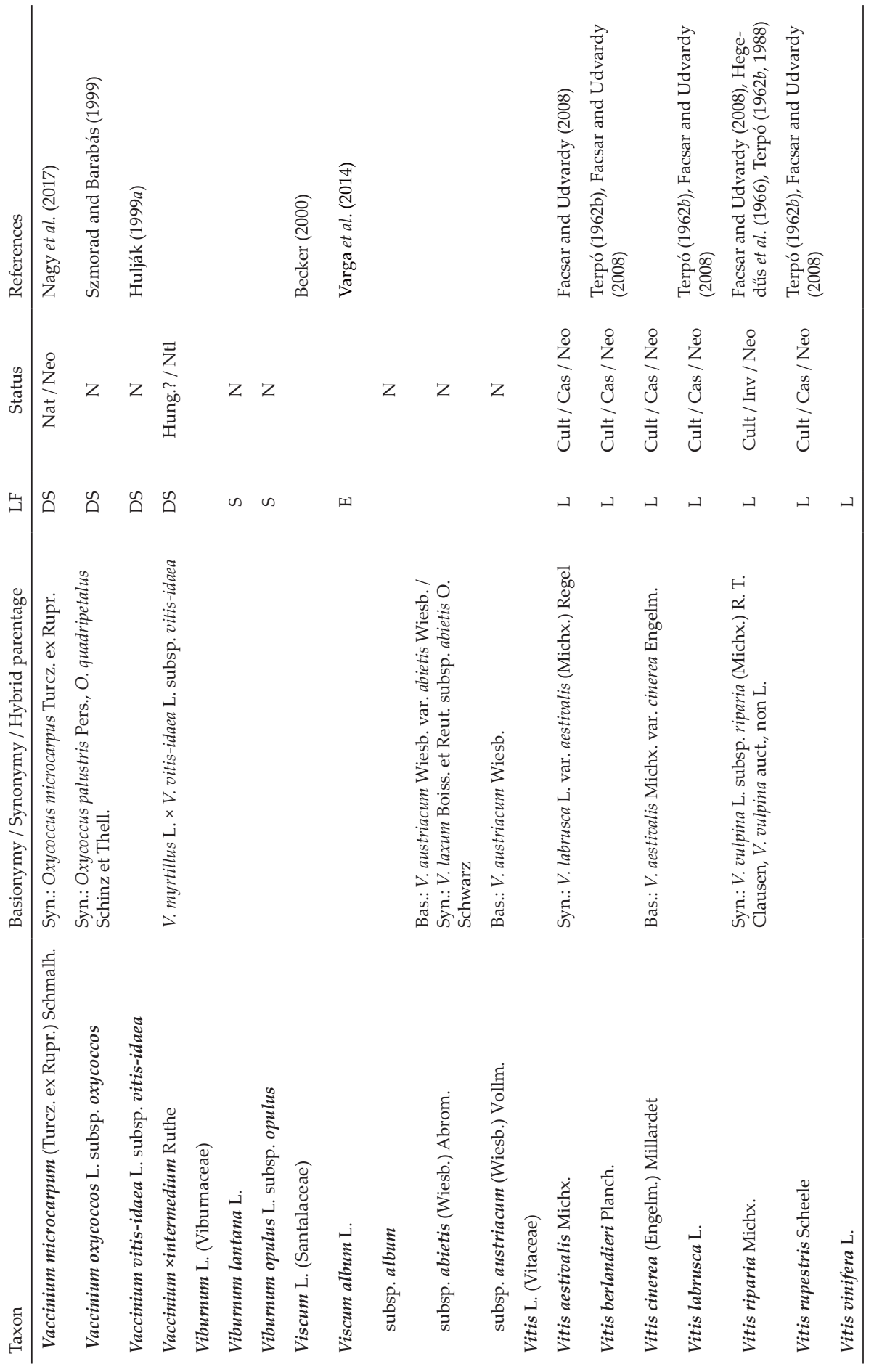




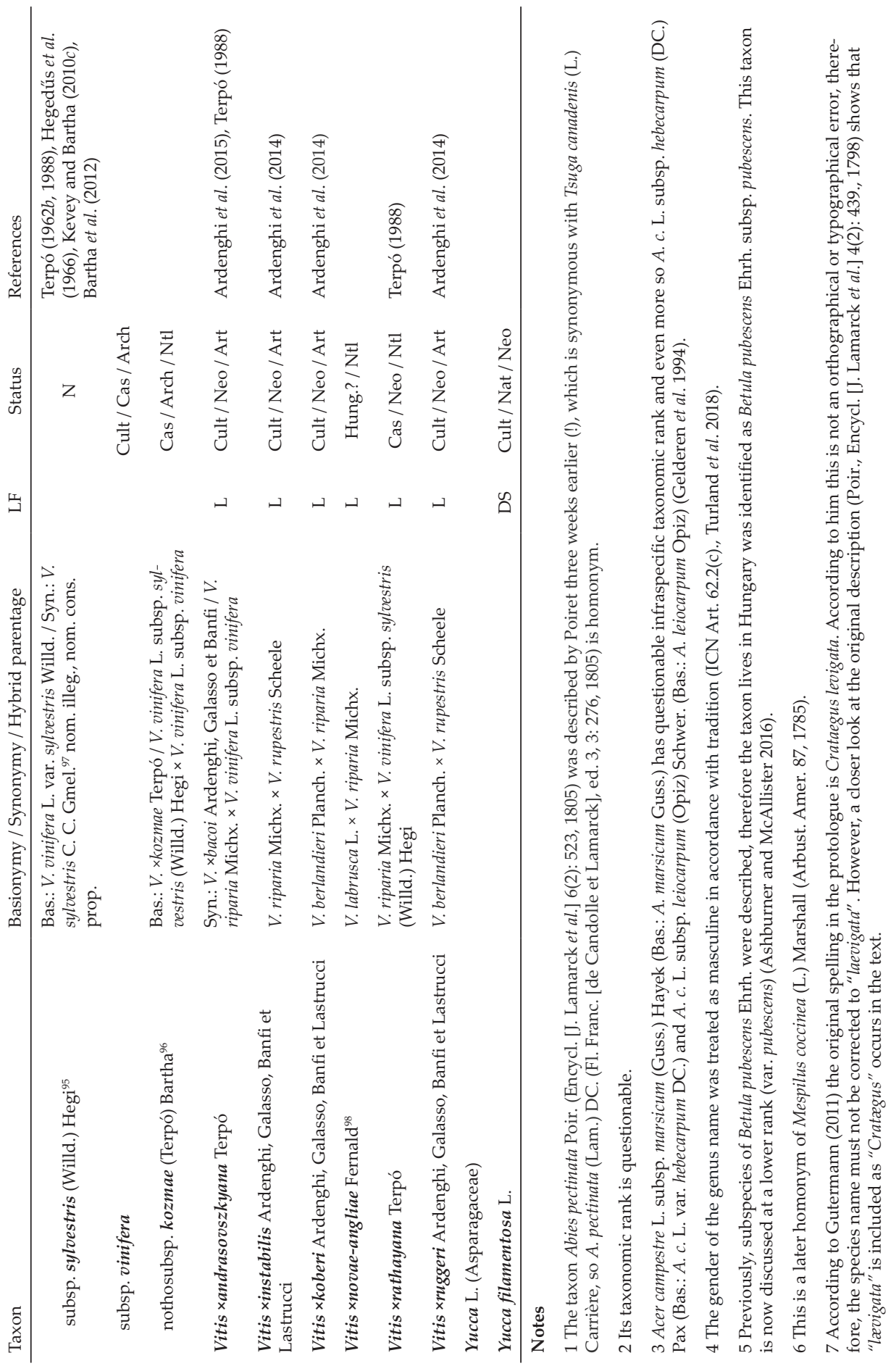




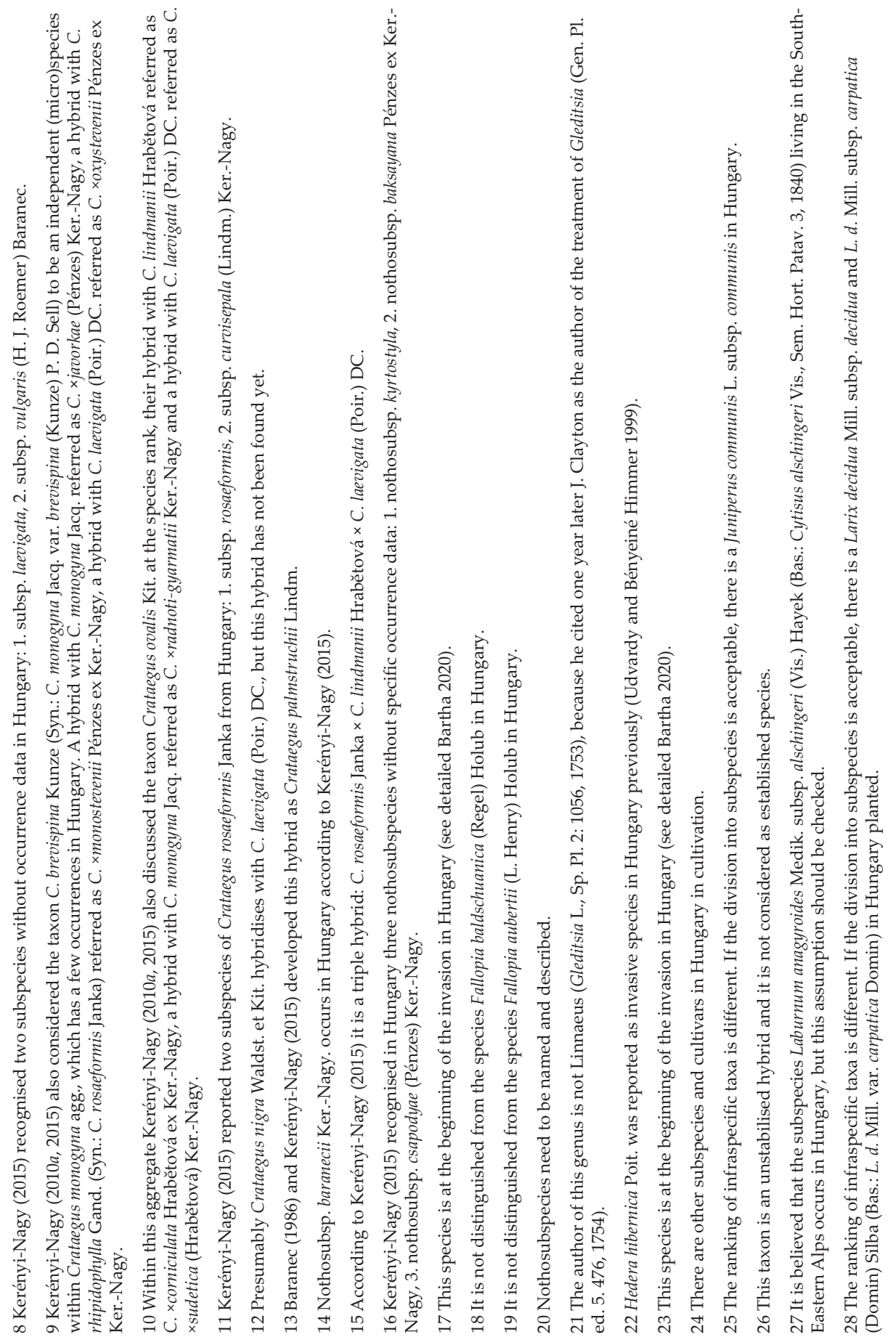




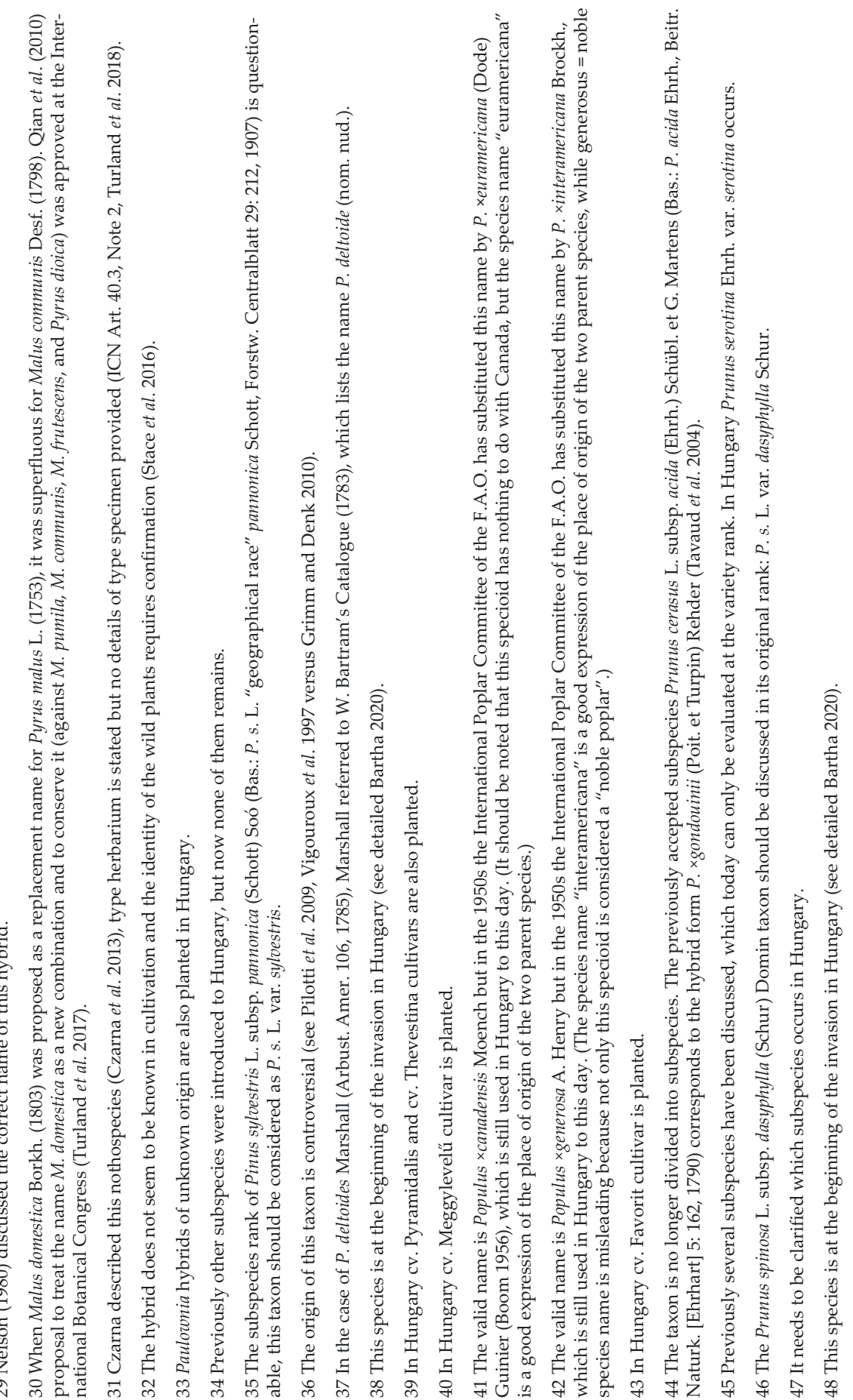




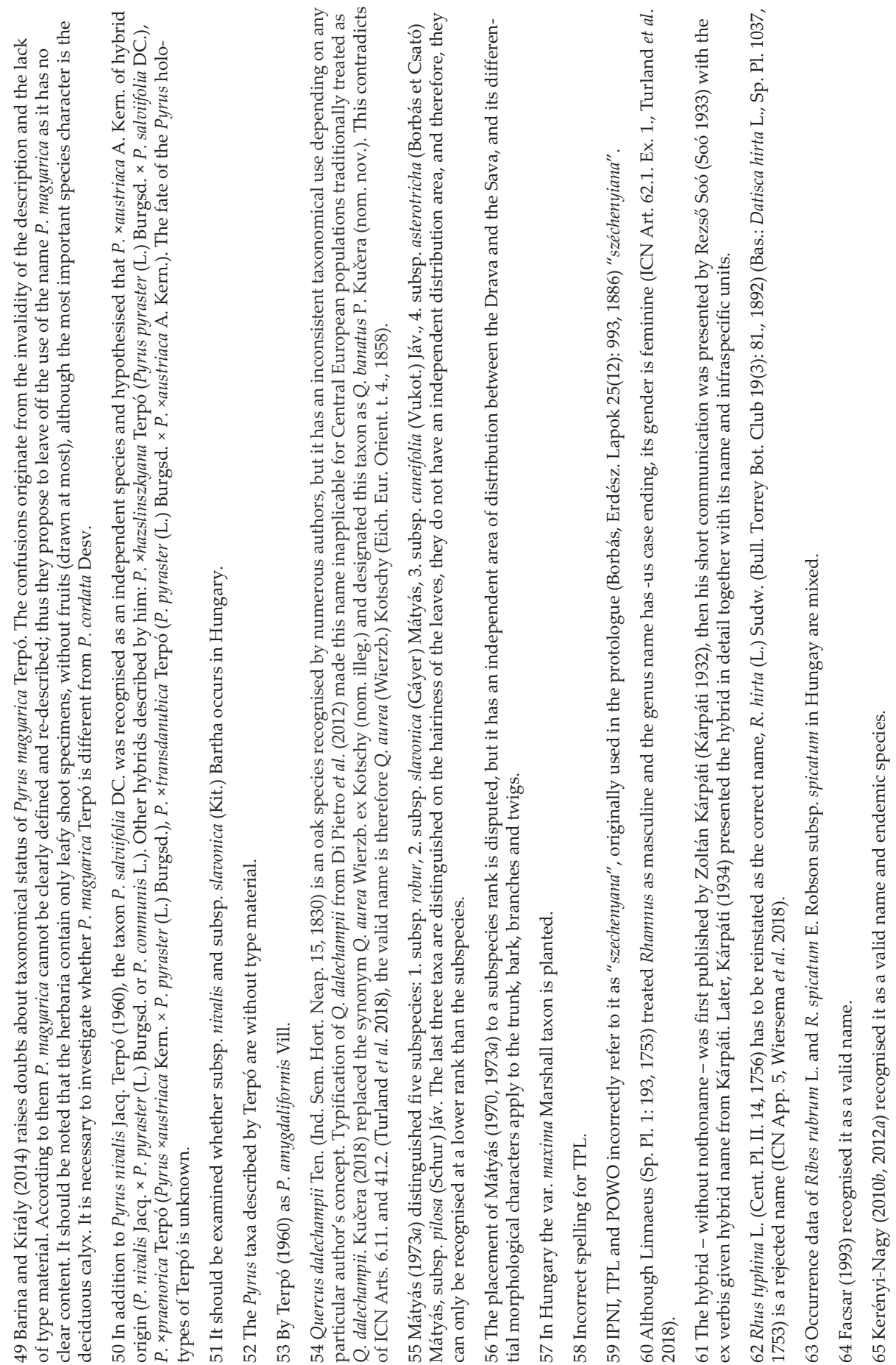




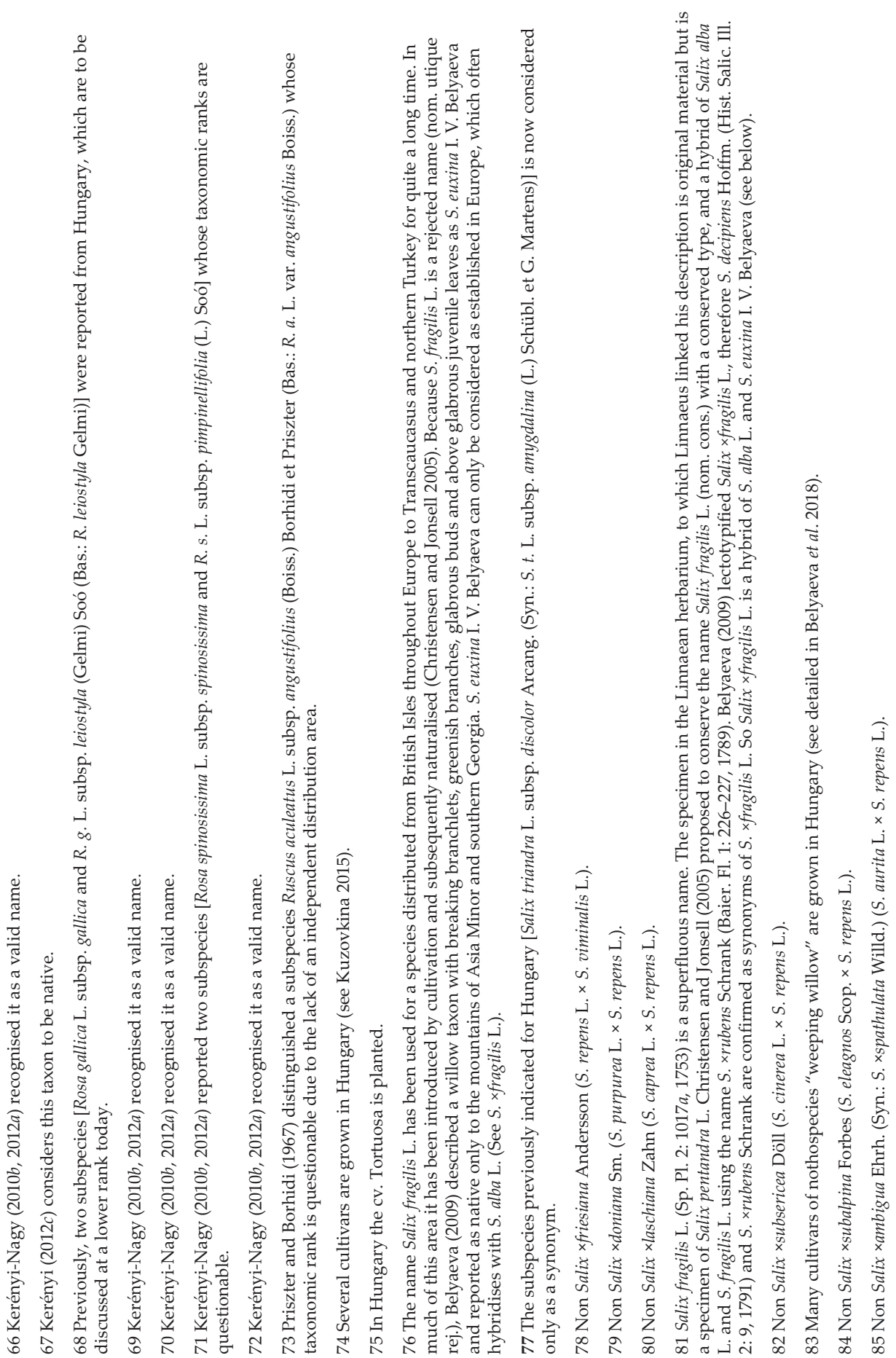




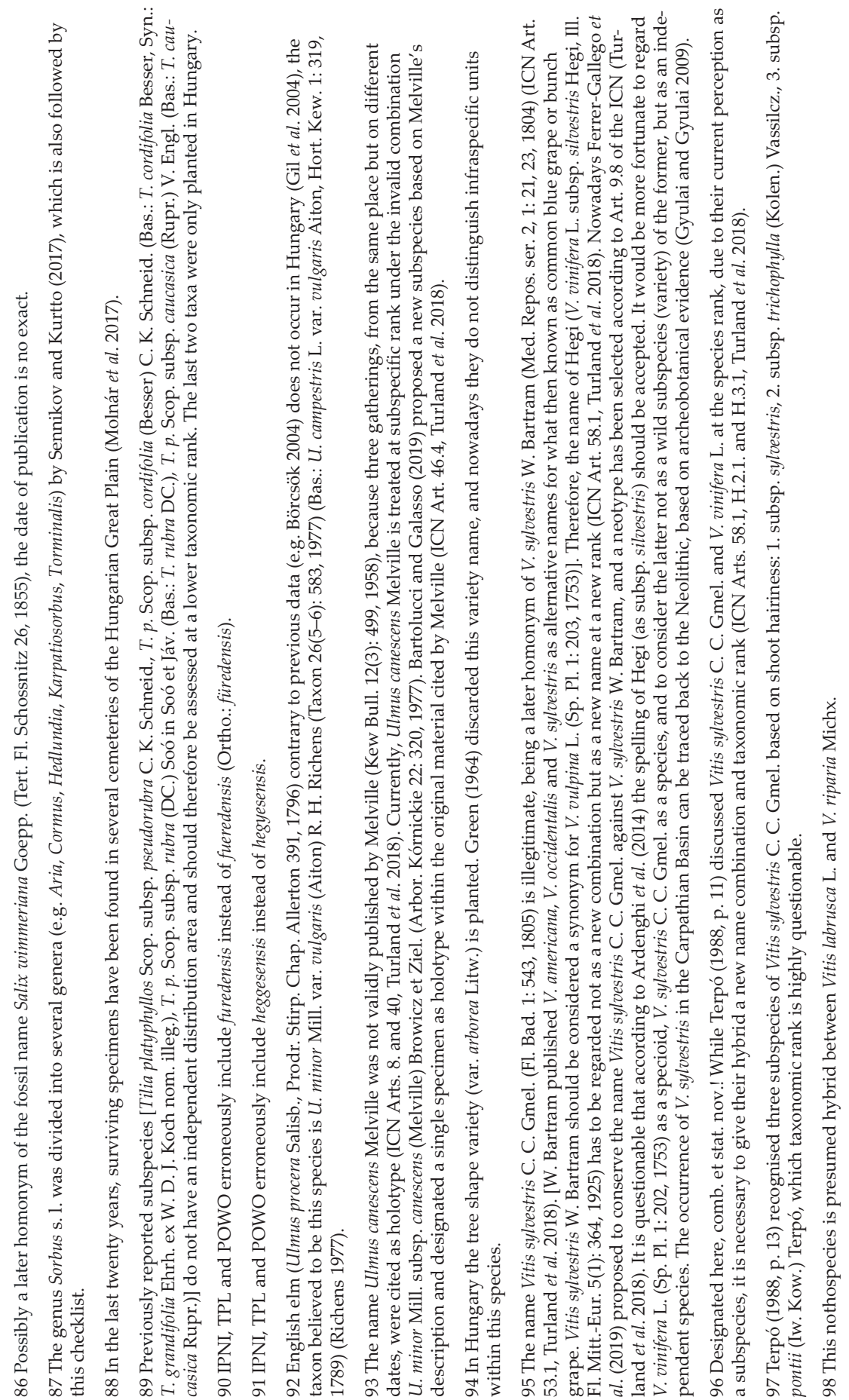

